\title{
Lake Providence to Old River Geomorphology Assessment
}

\section{MRG\&P}

Mississippi River Geomorphology \& Potamology Program

\section{MRG\&P Report No. 32 • April 2020}

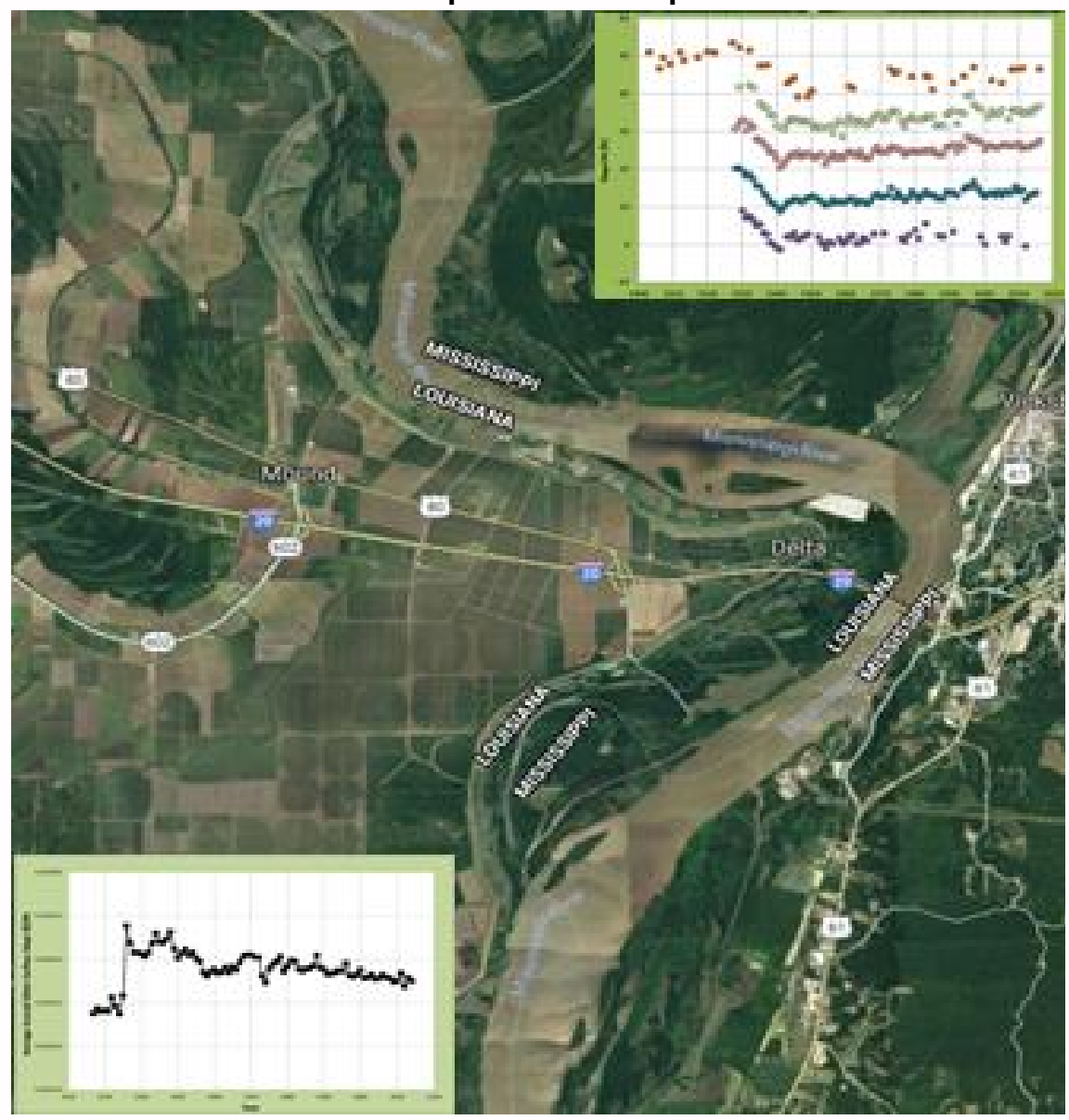





\section{Lake Providence to Old River Geomorphology Assessment}

Waleska Echevarria-Doyle and David S. Biedenharn

Coastal and Hydraulics Laboratory

U.S. Army Engineer Research and Development Center

3909 Halls Ferry Road

Vicksburg, MS 39180-6199

Charlie D. Little Jr.

Mendrop Engineering Resources, LLC

3530 Manor Drive, Suite 2

Vicksburg, MS 39180

Final report

Approved for public release; distribution is unlimited.

Prepared for U.S. Army Corps of Engineers, Mississippi Valley Division Mississippi River Geomorphology \& Potamology Program 1400 Walnut Street

Vicksburg, MS 39180

Under Project No. 470711 


\section{Abstract}

This report integrates information from previous geomorphic studies coupled with new analysis to provide a comprehensive geomorphic characterization of the Lake Providence (River Mile [RM] 487.2 Above Head of Passes [AHP]) to Old River Control Complex, (RM 317 AHP) reach from the early-180os to present. Individual components of this study included the following: historical geomorphic studies, development of an events timeline, specific gage records, stage and flow duration trends, trends in water surface slopes, bed material studies, suspended sediment data, channel geometry data, and effects of channel improvement features (cutoffs, dikes, revetment, and dredging). These individual assessments were consolidated to develop an overall assessment of how the study reach has evolved since the early-180os.

DISCLAIMER: The contents of this report are not to be used for advertising, publication, or promotional purposes. Citation of trade names does not constitute an official endorsement or approval of the use of such commercial products. All product names and trademarks cited are the property of their respective owners. The findings of this report are not to be construed as an official Department of the Army position unless so designated by other authorized documents. 


\section{Contents}

Abstract....................................................................................................................................... if

Figures and Tables.................................................................................................................................. iv

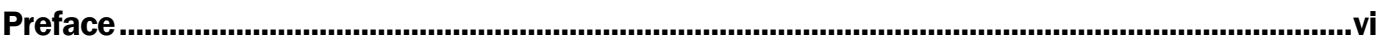

1 Introduction....................................................................................................................... 1

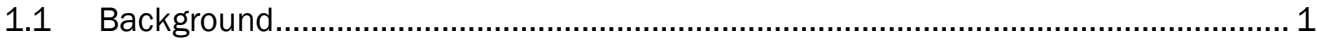

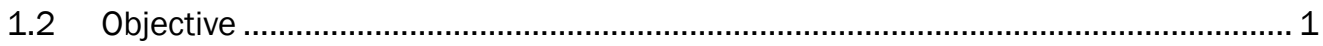

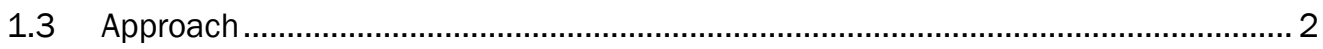

2 Geomorphic Changes Early-1800s to Present....................................................................... 3

$2.1 \quad$ Event timeline ................................................................................................ 3

2.2 Pre-cutoff Period (early-1800s to 1929) ............................................................... 4

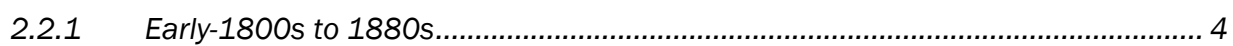

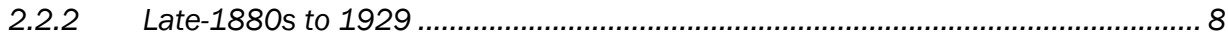

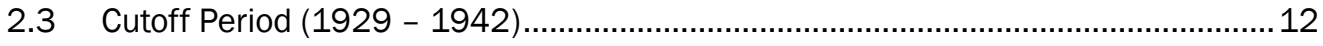

2.4 Post-cutoff Period (1943 - present) ................................................................. 14

2.4.1 Channel improvements (revetments, dikes, and dredging)....................................15

2.4.2 Flow regime in the Post-cutoff Period ................................................................. 18

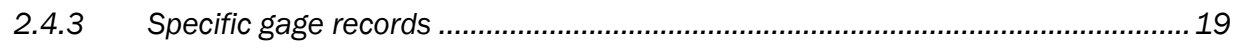

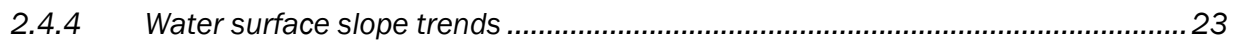

2.4.5 Stage duration changes...................................................................................... 31

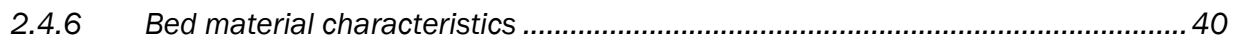

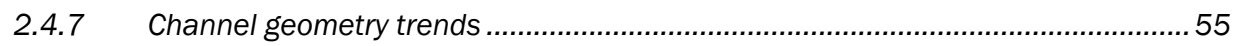

2.4.8 Suspended sediment trends ....................................................................... 57

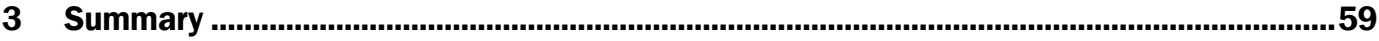

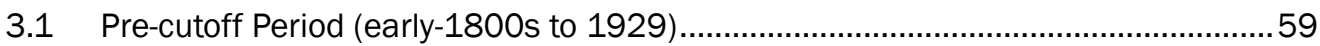

3.2 Cutoff Period (1929-1942) ...................................................................................60

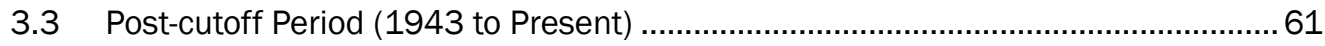

3.3.1 Channel improvements features...................................................................... 61

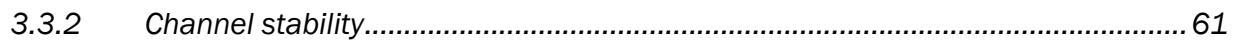

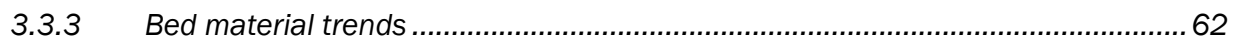

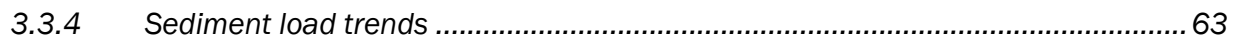

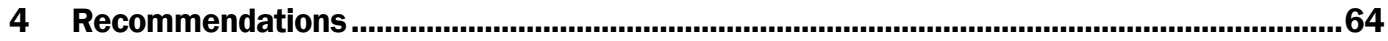

References....................................................................................................................................6

Unit Conversion Factors................................................................................................................ 70

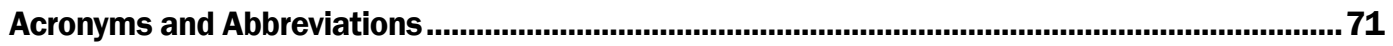

\section{Report Documentation Page}




\section{Figures and Tables}

\section{Figures}

Figure 2-1. Change in Mississippi River top bank width between 1820 and 1973 (adapted

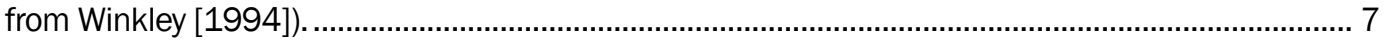

Figure 2-2. LMR valley flows before levees (Winkley 1977) ............................................................ 8

Figure 2-3. Average levee heights and peaks stages at Natchez, MS (Winkley 1977)................... 11

Figure 2-4. Specific gage records at Lake Providence and Vicksburg in the Pre-cutoff

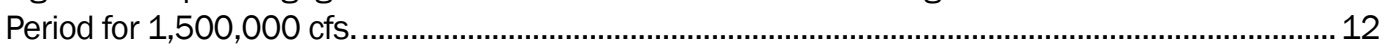

Figure 2-5. Specific gage records along the LMR (Winkley 1977) .................................................. 14

Figure 2-6. Revetment and dike construction timeline in the study reach..................................... 15

Figure 2-7. Total linear feet of revetments and dikes in study reach (by 10-mile increments).

Figure 2-8. Accumulated annual average bank caving volumes from the Arkansas River to the ORCC (Winkley 1973).

Figure 2-9. Relationship between total linear feet of dikes and maintenance dredging in the New Orleans, Vicksburg, and Memphis Districts..

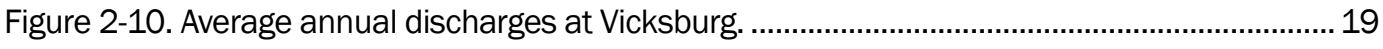

Figure 2-11. Specific gage record at Lake Providence, LA ............................................................... 21

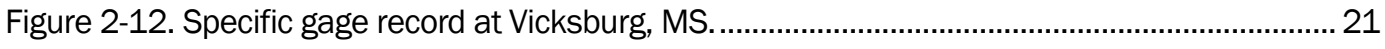

Figure 2-13. Specific gage record at St. Joseph, LA......................................................................... 22

Figure 2-14. Specific gage record at Natchez, MS...................................................................... 23

Figure 2-15. Average annual water surface slopes for the Lake Providence to Vicksburg

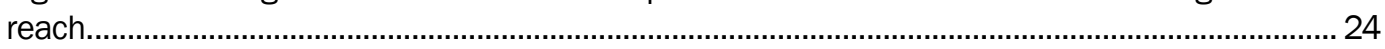

Figure 2-16. Water surface slope trends in the Vicksburg to St. Joseph reach. .............................26

Figure 2-17. Water surface slope trends in the St. Joseph reach to Natchez....................................28

Figure 2-18. Water surface slope trends in the Vicksburg to Natchez Reach.................................. 29

Figure 2-19. Lake Providence stage duration curve using time periods in Table 2-14....................33

Figure 2-20. Flow-adjusted stage duration curves at Lake Providence............................................3 34

Figure 2-21. Vicksburg stage duration curve using time periods in Table 2-14..............................35

Figure 2-22. Flow-adjusted duration curves at Vicksburg................................................................. 35

Figure 2-23. St. Joseph Stage duration curve using time periods in Table 2-14............................ 36

Figure 2-24. Flow-adjusted duration curve at St. Joseph. ................................................................ 37

Figure 2-25. Natchez stage duration curve using time periods in Table 2-14...............................38

Figure 2-26. Flow-adjusted duration curves at Natchez. ................................................................. 38

Figure 2-27. Bed Material trends at the Vicksburg gaging station. ................................................... 42

Figure 2-28. Box and whisker plot for the Vicksburg bed material data........................................ 42

Figure 2-29. Bed material trends at the Natchez gaging station. .....................................................43

Figure 2-30. Box and whisker plot for the Natchez bed material data. ........................................... 43

Figure 2-31. Downstream trends in $D_{50}$ in November 2013 - Study reach outlined in red (Gaines and Priestas 2016). 
Figure 2-32. Downstream trends in bed material grain size distributions in the LMR in (a) 1932, (b) 1989, and (c) 2013 - Study reach outlined in red (Gaines and Priestas 2016).

Figure 2-33. Selected bed material gradation curve in the research study.

Figure 2-34. Box and whisker plots of $D_{50}, D_{16}$, and $D_{84}$ for the 14 potamology reaches.

Figure 2-35. Cumulative volume change curves for the Vicksburg District. Study reach outlined in red.

\section{Tables}

Table 2-1. List of natural meander cutoffs in study reach between 1776 and 1884

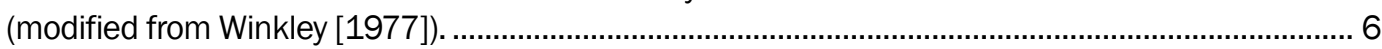

Table 2-2. Geomorphic reach characteristics (adapted from Schumm et al. [1994])...................... 9

Table 2-3. Man-made meander cutoffs, 1929 - 1942 (adapted from Winkley [1977]). ................ 13

Table 2-4. Average annual bank caving volumes in the Lake Providence to Old River reach for the Pre- and Post-revetment Periods. ...................................................................................... 17

Table 2-5. Specific gage locations within the study reach. .............................................................. 20

Table 2-6. Period of record and reach length data for the Lake Providence to Vicksburg reach.

Table 2-7. Average annual water surface slopes for three time periods in the Lake Providence to Vicksburg reach.

Table 2-8. Period of record and reach length data for the Vicksburg to St. Joseph reach.

Table 2-9. Average annual water surface slopes for three time periods in the Vicksburg to St. Joseph reach.

Table 2-10. Period of record and reach length data for the St. Joseph to Natchez reach.

Table 2-11. Average annual water surface slopes for three time periods in the St. Joseph to Natchez reach.

Table 2-12. Period of record and reach length data for the Vicksburg to Natchez reach

Table 2-13. Average annual water surface slopes for three time periods in the Vicksburg to Natchez reach. 30

Table 2-14. Time periods used in the development of the stage duration curves. 31

Table 2-15. Selected years with similar average daily discharges. 32

Table 2-16. Stage duration changes for a range of flow conditions. 40

Table 2-17. Fourteen potamology reaches used in the bed material analysis. 48

Table 2-18. Bed classification from 2005 and 2007 geo-referenced videos. 51 


\section{Preface}

This study was performed for the U.S. Army Corps of Engineers, Mississippi Valley Division, Mississippi River Geomorphology \& Potamology Program, Project No. 470711. The MRG\&P Program is part of the Mississippi River and Tributaries Program and is managed by the U.S. Army Corps of Engineers (USACE) Mississippi Valley Division (MVD) in Vicksburg, MS. The MRG\&P Technical Director was Dr. James W. Lewis. The MVD Commander was MG Richard G. Kaiser. The MVD Director of Programs was Mr. Jim Bodron.

Direct supervision of the U.S. Army Engineer Research and Development Center (ERDC), Coastal and Hydraulics Laboratory (CHL) aspects of this effort were provided by Dr. Cary A. Talbot, Chief of the Flood and Storm Protection Division, and Mr. Keith W. Flowers, Chief of the River and Estuarine Engineering Branch. The Deputy Director of CHL was Mr. Jeffrey R. Eckstein, and the Director was Dr. Ty V. Wamsley.

The Commander of ERDC was COL Teresa A. Schlosser, and the Director of ERDC was Dr. David W. Pittman. 


\section{Introduction}

\subsection{Background}

The Mississippi River has been molded by anthropogenic and natural factors for thousands of years. Early efforts by the U.S. Army Corps of Engineers (USACE) to manage the river for navigation began in the early1800 , with the most comprehensive efforts occurring as a result of the Flood Control Act (FCA) of 1928 following the Flood of 1927. The Mississippi River \& Tributaries (MR\&T) project that was authorized from the FCA of 1928 has produced a massive, comprehensive system for flood control and channel stabilization that includes levees, channel modifications, and floodways, as well as tributary reservoirs and other basin improvements. The first official "Potamology Investigations" were initiated in the mid-1940s. These potamology studies continued as an integral component of the MR\&T Program until the 1980s when the program ended. As a result of this, the USACE realized it had basically lost decades of continued potamology advancement along with a generation of experienced staff with that important knowledge. In response to this need, the Mississippi River Geomorphology and Potamology (MRG\&P) program was created by the USACE Mississippi Valley Division (MVD) in 2014. MRG\&P studies are designed to provide a comprehensive analysis of physical and anthropogenic factors that influence the flood conveyance capacity, navigability, and environmental quality of the Mississippi River. The purpose of the studies is to identify cause-effect and process-response relationships that result in short- and long-term changes in the hydrology, hydraulics, and morphology of the Mississippi River. Additional purposes are to develop improved design approaches and criteria for construction of channel improvement actions that will result in flood damage reductions, enhanced navigation, and environmental sustainability. The report presented herein represents one component of the MRG\&P Program.

\subsection{Objective}

Over the past few years, there have been numerous individual studies that addressed various geomorphic aspects of the river. This report represents an integration of these studies combined with new analyses to weave together a more comprehensive understanding of the geomorphic character for the specific study area between Lake Providence, LA (River 
Mile [RM] 487.2 Above Head of Passes [AHP]), and the Old River Control Complex (ORCC) (RM 317 AHP). The study included the development of a timeline and analysis of specific gage records, stage duration curves, channel geometry trends, bed material data, and meander migration information within this reach.

\subsection{Approach}

The approach used to perform a geomorphic assessment of the study reach include the following elements: (1) event timeline from early-180os to present; (2) general description of the pre-cutoff period (early-18oos to 1929) morphological trends; (3) description of the cutoff period (1932 1942), and post-cutoff period (1943 - present) geomorphic changes; and (4) analysis of specific gage records, stage-duration curves, channel geometry trends, bed and suspended material data, and meander migration information within the reach. 


\section{Geomorphic Changes Early-1800s to Present}

This chapter discusses the geomorphic changes in the study reach from the early-180os to present. The first section is an event timeline that lists some of the major natural and anthropogenic factors that have occurred during the study period. The next three sections describe the major geomorphic characteristics during three broad time periods: (1) Pre-cutoff Period (prior to 1929); (2) the Cutoff Period (1929 - 1942); and (3) Postcutoff Period (1943 - present).

\subsection{Event timeline}

A chronology of the major river engineering, hydrologic, and anthropogenic events within the study reach was developed for the study time period. The timeline is presented to add insight into the interpretation of the results from other analyses presented in this report.

- 1800 - Mid-18oos. Massive clearing of streambanks and riparian areas for wood-burning steamboats and agriculture.

- 1811 - 1812 - New Madrid earthquakes.

- $1849-1850$ - Repeated flooding along the Mississippi River Valley.

- Flood of 1874 - Results in creation of Levee Commission.

- 1879 - Mississippi River Commission (MRC) created.

- 1879 - 1928 - Levees-only policy adopted by MRC.

- $1884-1929$ - MRC adopts policy to prevent natural neck cutoffs from forming. Natural chute cutoffs were allowed to continue during this period. Natural neck or meander cutoffs occur when the river flow breaches between the two bends of a meander creating a new channel alignment. Chute cutoffs occur as a result of recurring large flows across the inside of point bars. Also, chute cutoff can form upstream of a neck cutoff due to head cutting or degradation caused by the neck cutoff and downstream of a neck cutoff due to aggradation forming a middle bar (Winkley 1977).

- 1890 Flood

- Floods of 1913

- 1927 Major Flood. For this timeline, a major flood is defined as an event with a peak discharge of approximately 1.9 million cfs or more recorded at the Vicksburg USGS gage 07289000. 
- 1928 - FCA of 1928 results in creation of Mississippi River \& Tributaries (MR\&T) Project.

- 1929 - MRC allows the Yucatan cutoff to occur, which was the first natural neck cutoff allowed since 1884 .

- 1930 - 1934 - Low-water period. For this timeline, a low-water period is defined as a period with peak discharges of approximately 1.6 million cfs or less recorded at the Vicksburg USGS gage 07289000.

- 1932 - 1942 - Cutoff Period (15 meander cutoffs between just south of Natchez, MS, and just north of Helena, AR).

- 1937 Major Flood

- 1940 - Studies indicate potential of Atchafalaya capturing Mississippi River Flow.

- 1940-1944 - Low-water period.

- 1950 - Mid 1990s - Major bank stabilization period.

- Mid 1960s - early 2000s - Major dike construction period.

- 1952 - 1972 - Low-water period.

- 1963 ORCC Low Sill Structure in operation.

- 1973 - Major flood

- 1975 Flood

- 1984 - 1988 - Low-water period.

- 1986 - ORCC Auxiliary Structure in operation.

- 1990 - ORCC Hydropower Unit in operation.

- 1993 - Major flood on upper Mississippi River.

- Mid 1990s - Dike-notching program begins.

- 1997 - Flood

- 2000 - Extreme low-water year. The published maximum daily average discharge at the Vicksburg USGS gage 07298000 is $787,000 \mathrm{cfs}$.

- 2008 Flood

- 2011 Major flood

- 2012-2014 - Low-water period.

\subsection{Pre-cutoff Period (early-1800s to 1929)}

The Pre-cutoff phase is divided into two general time periods: (1) early1800 s to late-1870s and (2) late-1870s to 1929 . A general description of the morphologic trends in these two time periods is provided below.

\subsubsection{Early-1800s to 1880s}

The early-180os was a period of rapid expansion into the Lower Mississippi River Valley, and navigation along the waterways was the key 
to the growth of this region. Unfortunately, the Mississippi River was experiencing dramatic geomorphic changes as a result of both natural and anthropogenic factors during this initial period of expansion. The first factor was the series of New Madrid earthquakes that occurred for almost 2 years during the 1811 to 1812 period. Winkley (1994) mentions that an increase in meander rates and number of middle bars was observed after the earthquakes when comparing post-1811-1812 New Madrid Earthquakes surveys with the 1765 survey. Additionally, these earthquakes resulted in massive bank instabilities throughout the river and caused excessive sediment supply, bar growth, and navigation problems (Winkley 1977). The system became overloaded with sediment and trees from caving banks, and numerous bars and islands were reported to have disappeared during the earthquakes.

The early-180os saw the introduction of the wood-burning steamboats along the Mississippi River. These steamboats required massive amounts of fuel (wood), which was supplied from the numerous woodyards that sprang up along the river during this period. This resulted in thousands of acres of streambanks being cleared, which, when combined with the land clearing along the natural levees for agriculture, significantly contributed to accelerated bank erosion and sediment supply to the system (Winkley 1977).

Six natural meander cutoffs occurred in the study reach between 1776 and 1884, shortening the river by approximately 78 miles (Table 2-1). Although specific dates are listed in Table 2-1, it should be recognized that these cutoffs typically did not develop instantaneously but rather generally took many years to completely develop. Meanwhile, the river was obtaining additional length elsewhere through meander growth, such that, according to Winkley (1977), the overall river lengths for the entire Lower Mississippi River in 1765 (the first map of the Lower Mississippi River) and 1884 were nearly the same. 
Table 2-1. List of natural meander cutoffs in study reach between 1776 and 1884 (modified from Winkley [1977]).

\begin{tabular}{|l|c|c|c|}
\hline Natural Cutoff & 1962 AHP River Mile & $\begin{array}{c}\text { Year Cutoff } \\
\text { Occurred }\end{array}$ & $\begin{array}{c}\text { River Length Reduction by } \\
\text { Cutoff (miles) }\end{array}$ \\
\hline Terrapin Neck & 462 & 1866 & 16 \\
\hline Yazoo & 442 & 1799 & 12 \\
\hline Centennial Lake & 438 & 1876 & 6 \\
\hline Davis or Palmyra & 422 & 1867 & 19 \\
\hline Waterproof & 377 & 1884 & 12 \\
\hline Homochitto & 322 & 1776 & 13 \\
\hline Total & & & 78 \\
\hline
\end{tabular}

Bank erosion, meander cutoffs, and bar and island changes may, in many instances, simply be part of the natural processes of a river that is in a state of dynamic equilibrium. However, the dramatic changes observed during this time period are indications that these natural processes had been disrupted and the channel was in a period of morphologic adjustment as it attempted to regain dynamic equilibrium. The magnitude of these changes is illustrated in Figure 2-1, which shows changes in the average top bank width for the reach of river between Vicksburg (RM 435) and the Red River (RM 312). Although there is uncertainty in the surveys during these older time periods, they do provide a good approximation of the order of magnitude of the width changes in the river. The survey of 1821 was the first available survey after the $1811-1812$ earthquakes. Comparisons between this 1821 survey with the survey of 1880 showed that the average top bank width in this reach increased from approximately 2,500 feet (ft) to approximately $4,700 \mathrm{ft}$, or approximately $91 \%$. Width increases of this magnitude would not be compatible with the natural meandering processes of a river in dynamic equilibrium but rather would be indicative of a river experiencing severe system instabilities. Identifying all the causes for this systematic instability is difficult, but the New Madrid earthquakes, coupled with the clearing of the streambanks and adjacent riparian areas, appear to be the dominant factors during this period. 
Figure 2-1. Change in Mississippi River top bank width between 1820 and 1973 (adapted from Winkley [1994]).

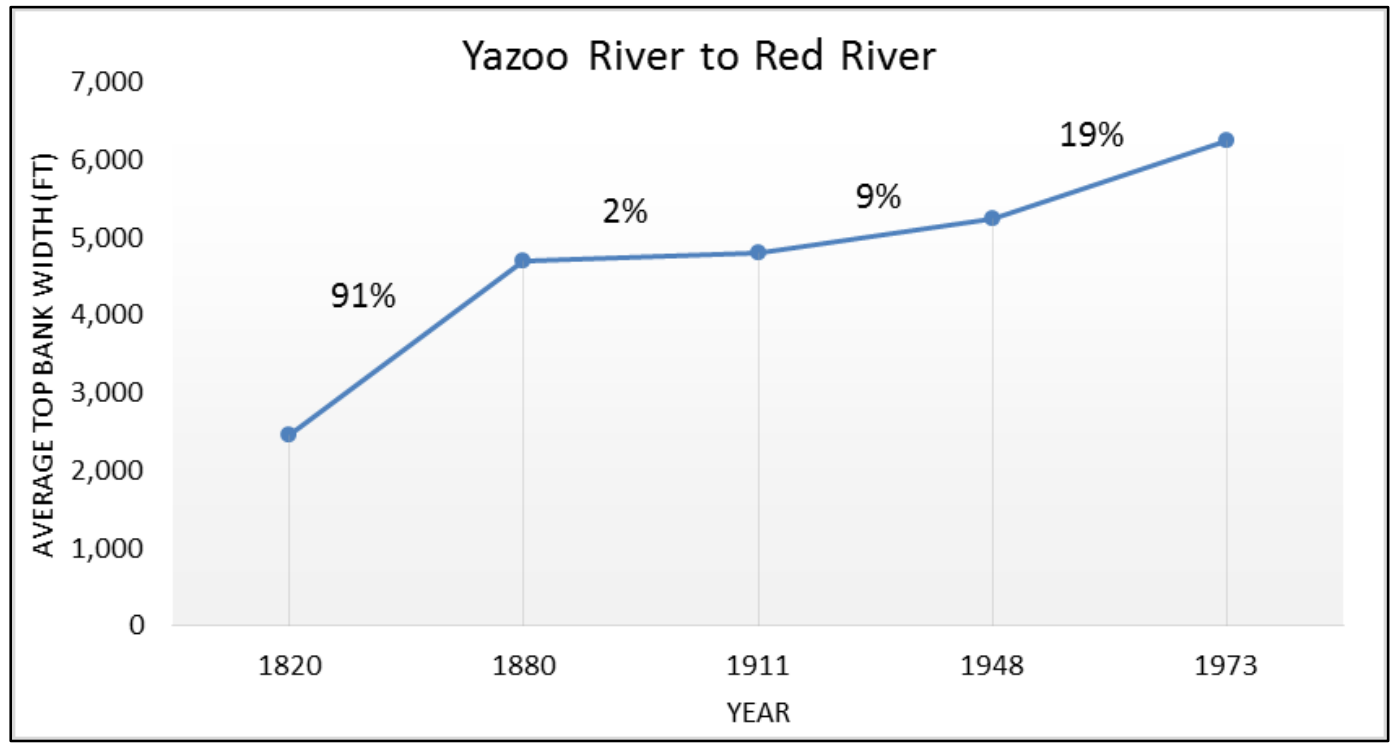

Prior to building levees, the entire Lower Mississippi River (LMR) valley below Cairo, IL, was a delta. Distributary channels carried high as well as some lower flows into various lowland basins. Figure 2-2 illustrates the spatial distribution of flood flows prior to levees. Flood protection began in the LMR valley in the early 1700 , but it was localized and discontinuous. Major floods in the mid- to late-180os caused severe damage to some of these early levees. After the disastrous flood of 1874, a levee commission was created with the intent to evaluate and make recommendations for the levee system (Elliot 1932). However, it was not until the creation of the MRC in 1879 (see next section) that a more comprehensive approach was adopted.

In summary, the LMR was undergoing significant morphological changes during this time period. The instabilities were driven by various factors, most notably the New Madrid earthquakes and clearing of the streambanks for wood-burning steamboats and agriculture. It is unfortunate that the river was undergoing such drastic morphologic changes just as the nation was beginning to use the river and settle into the Mississippi River valley. Many of the early navigation problems on the river were aggravated by the caving streambanks, bar building, and channel widening, which created a negative impression of the river system just as it was becoming the main navigation artery for the country. 
Figure 2-2. LMR valley flows before levees (Winkley 1977).

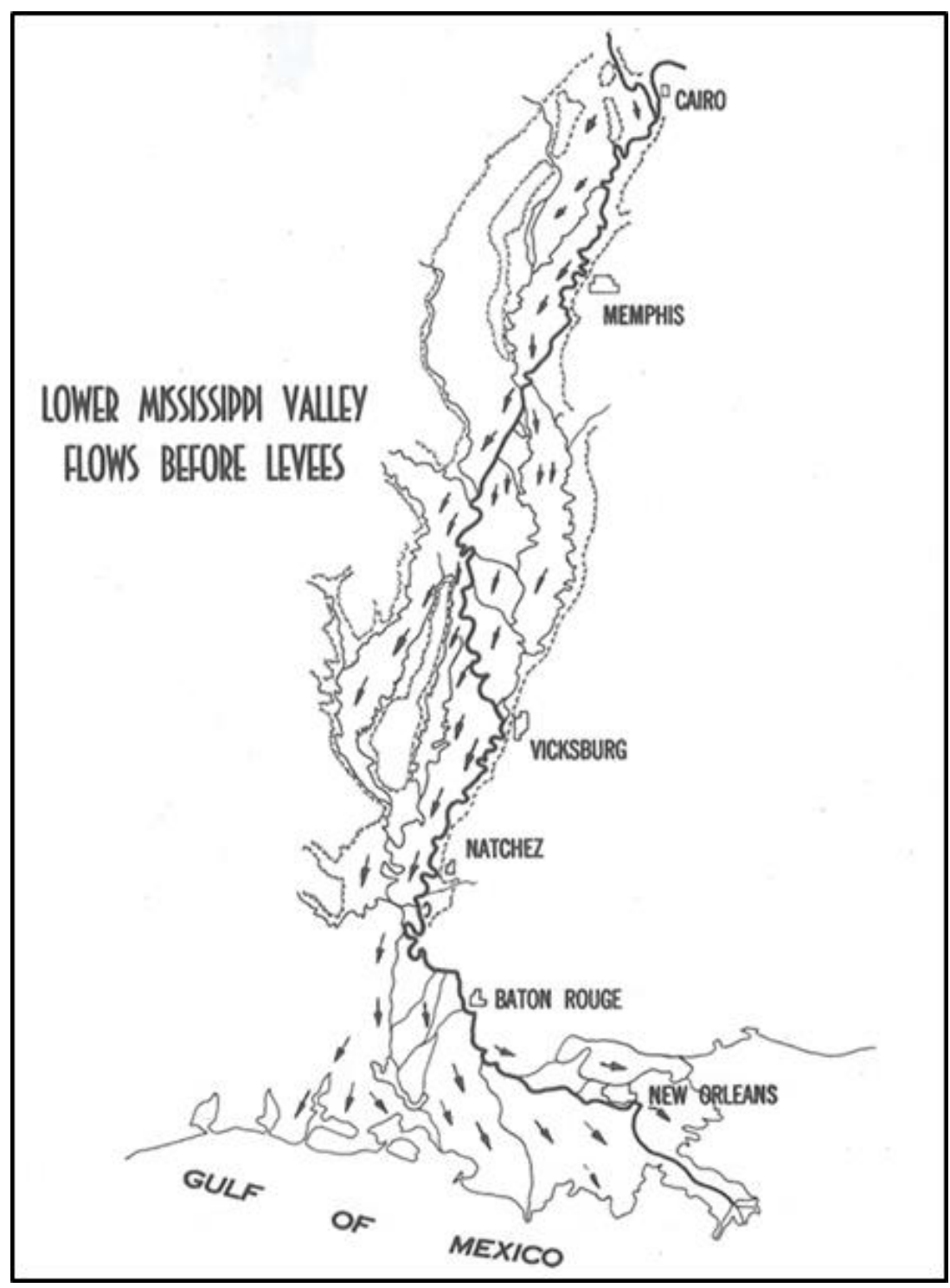

\subsubsection{Late-1880s to 1929}

Schumm et al. (1994) subdivided the LMR in 24 reaches based on morphological characteristics and behavior in the Pre-cutoff time period. Reaches 21 through 24 cover the study reach (Lake Providence to Old River). Table 2-2 shows a summary of the characteristics of the geomorphic reaches 21 through 24 . The reach boundaries are identified by 1962 river miles (RM), but the reach lengths reflect 1880 river mileage. Therefore, the lengths are not directly comparable to the 1962 reach lengths. Reach patterns varied from sinuous (RM 484 to 405) to moderate sinuosity (RM 405 to 304 ). 
Table 2-2. Geomorphic reach characteristics (adapted from Schumm et al. [1994]).

\begin{tabular}{|c|c|c|l|c|l|}
\hline $\begin{array}{c}\text { Schumm } \\
\text { Reach No. }\end{array}$ & $\begin{array}{c}\text { Reach } \\
\text { Boundary }\end{array}$ & $\begin{array}{c}\text { Length in } \\
\text { 1880 RM }\end{array}$ & Reach Pattern & $\begin{array}{c}\text { Projected } \\
\text { Channel } \\
\text { Slope } \times \\
10^{4}\end{array}$ & $\begin{array}{l}\text { Possible } \\
\text { Control }\end{array}$ \\
\hline 21 & $484-437$ & 52 & sinuous & 0.77 & $\begin{array}{l}\text { lithology, } \\
\text { Monroe Uplift }\end{array}$ \\
\hline 22 & $437-405$ & 33.5 & sinuous & 1.30 & lithology \\
\hline 23 & $405-370$ & 50.5 & $\begin{array}{l}\text { moderate } \\
\text { sinuosity }\end{array}$ & 0.62 & lithology \\
\hline 24 & $370-304$ & 87 & $\begin{array}{l}\text { moderate } \\
\text { sinuosity }\end{array}$ & 0.65 & $\begin{array}{l}\text { lithology, } \\
\text { tributary (Red } \\
\text { River) }\end{array}$ \\
\hline
\end{tabular}

The MRC, established in 1879 , was created to plan and execute projects to improve navigation along the LMR. The MRC received federal funds from Congress for the construction of levees under a policy that considered levees part of the navigation improvement program. The MRC considered various options to provide dependable navigation within the LMR. The approaches considered included levees, reservoirs, outlets, and cutoffs. After considerable debate, the MRC settled on a levees-only policy. This approach was based on the assumption that the construction of levees would deepen the channel, thereby providing adequate navigation depths. The MRC recommended the design of levee grades that could contain the most frequent floods. The levee construction started in 1882 to complete the gaps along the existing levee system.

As the average levee height increased and crevasses became less pronounced, peak flood stage height began to increase as the flow between the levees became more confined. This is illustrated in Figure 2-3, which shows the peak annual stages at Natchez, MS, from the early-180os to 1980 (Winkley 1977). As shown in Figure 2-3, the peak stages began to increase in the early-1900s up to the 1930 s when the cutoffs temporarily lowered stages.

The MRC also adopted a no-cutoff program in 1884 with the goal of preventing natural meander cutoffs (aka neck cutoffs) from occurring. This was accomplished by implementing bank stabilization in areas where a natural cutoff was considered likely. As a result of this policy, the Waterproof cutoff (RM 377), which occurred naturally in 1884, was the last meander cutoff allowed until 1929 when the MRC decided to allow 
the Yucatan cutoff just south of Vicksburg to develop. As discussed in Section 2.2.1, six natural cutoffs occurred in the 108-year period prior to 1884. Therefore, it is only reasonable to assume that in the 45-year period between 1884 and 1929, several natural cutoffs would have naturally occurred without the intervention of the MRC policy. With the prevention of neck cutoff development, it is natural to assume that the length of the river would have increased dramatically during this period due to meander migration. However, this meander growth was somewhat offset by the numerous chute cutoffs that were allowed to develop during this period. These chute cutoffs shortened the river by approximately 45 miles in the reach from Cairo, IL, to Vicksburg, MS, and as a consequence, the river only increased in length in this reach by approximately 14 miles between 1884 and 1929 (Winkley 1977). Winkley also noted that the rate of chute cutoffs increased dramatically from only 0.09 chute cutoffs/year prior to 1884 to 0.29 chute cutoffs/year from 1884 to 1929 . This suggests that the river responded to the prevention of neck cutoffs by accelerating the development of chute cutoffs.

As discussed in Section 2.2.1, the LMR was undergoing significant morphologic changes prior to the 188 os. This is supported by the $91 \%$ increases in channel width during this period (Figure 2-1). However, as shown in Figure 2-1, the channel width only increased by approximately 2\% between 1880 and 1911 and approximately 9\% between 1911 and 1948 . The slight increase (9\%) between 1911 and 1948 probably reflects the effects of the man-made cutoffs between 1929 and 1942 (see section 2.3). This seems to indicate that the dramatic channel changes that characterized the pre-1880 period had slowed in the post-1880s.

Winkley (1977) suggested that the LMR prior to 1927 was losing channel capacity (aggradation) at all gages. Specific gage records, developed at Lake Providence, Vicksburg, St. Joseph, and Natchez, were examined to determine if aggradational trends were evident during this period. Unfortunately, historical data prior to the 1930 s were only available at Lake Providence and Vicksburg. As shown in Figure 2-4, the channel does appear to be slightly aggradational at high flows $(1,500,000$ cubic feet per second [cfs]) prior between 1900 and 1930.

For a while, it appeared that the levees-only approach was going to be successful. Numerous floods occurred during this period, and although there were some issues, the overall system seemed to perform satisfactorily. 
This all changed with the devastating flood of 1927 . The 1927 flood was one of the worst natural disasters in U.S. history, and as a result of this flood, the MRC recognized that a more comprehensive approach was going to be needed to provide adequate flood control and navigation on the LMR.

Figure 2-3. Average levee heights and peaks stages at Natchez, MS (Winkley 1977).

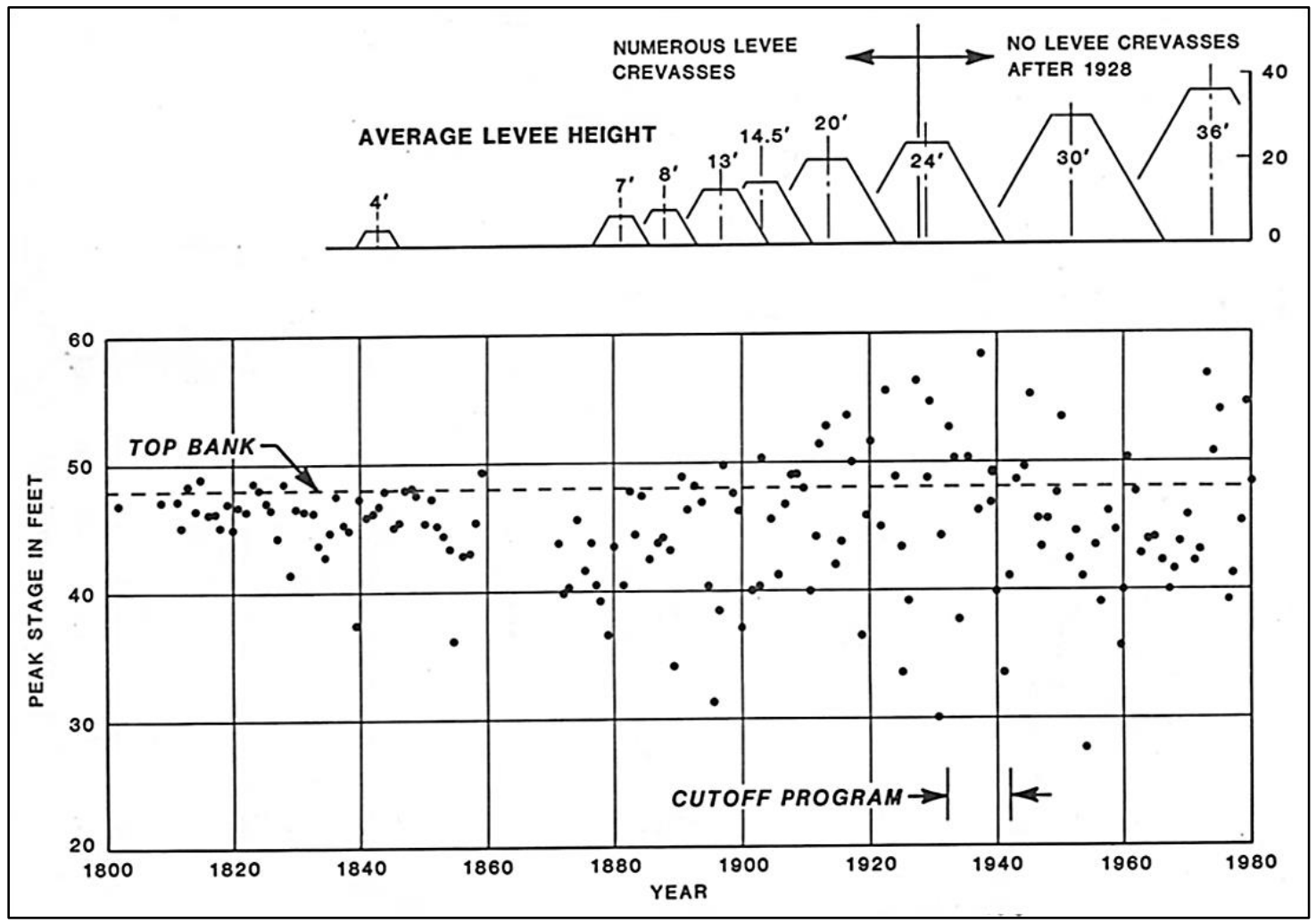


Figure 2-4. Specific gage records at Lake Providence and Vicksburg in the Pre-cutoff Period for 1,500,000 cfs.

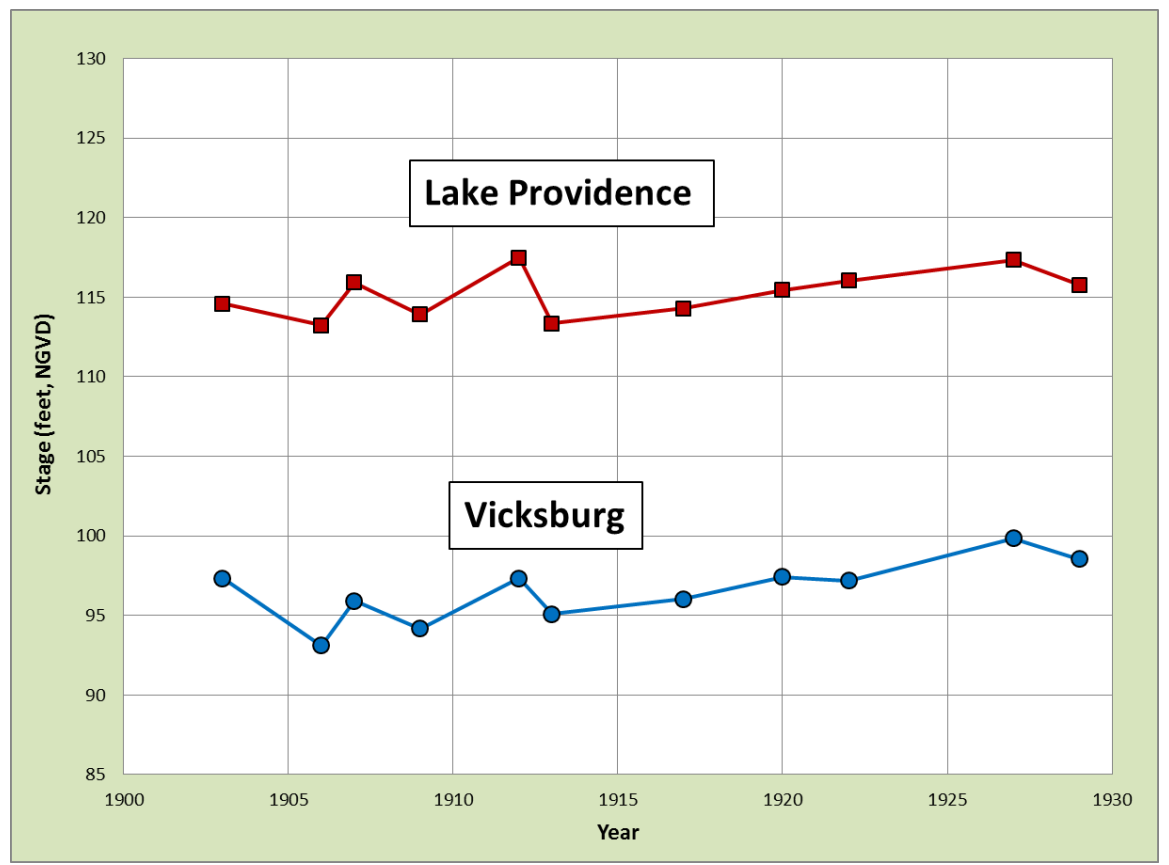

\subsection{Cutoff Period (1929 - 1942)}

This section discusses the geomorphic changes in the study reach that have occurred in the Cutoff Period (1929 - 1942).

The advantages and disadvantages of artificial cutoffs on the Mississippi

River had been debated without consensus by river engineers since the mid1880s. As discussed in Section 2.2, the MRC adopted a cutoff prevention program between 1884 and 1929. However, following the 1927 flood, the MRC again revisited the idea of incorporating artificial cutoffs on the river as one component of the MR\&T Project. In 1929, the first natural meander cutoff since 1884 was allowed to occur at the Yucatan Bend downstream of Vicksburg as part of a study to evaluate the response of the river to a cutoff. After monitoring the Yucatan cutoff for 2 years, the MRC initiated the cutoff program in 1931. Through this program, the USACE constructed 14 artificial cutoffs and allowed 2 natural cutoffs (Yucatan and Leland) to develop between 1929 and 1942 on the LMR. The locations of the cutoffs are shown in Table 2-3. These cutoffs shortened the river between Memphis, TN, and Old River, LA, by approximately 152 miles. Since 1942, no neck cutoffs have been constructed or allowed to develop. However, between 1932 and 1955, chute cutoffs were constructed at 40 locations between Cairo, IL, and Natchez MS, further shortening the river by another 55 miles. Following the cutoffs, meander migration continued as the river attempted to regain some 
of its length. This continued until the 1960 s when further meander migration was essentially terminated by the revetment program. However, according to Winkley (1977), these length increases were offset by the chute cutoffs so that the river is still approximately 150 miles shorter today than prior to the cutoffs.

The study reach included seven cutoffs: Willow, Marshall, Diamond, Yucatan, Rodney, Giles, and Glasscock. These cutoffs shortened the study reach by approximately 62 miles. (For a more detailed description of these cutoffs, the reader is referred to Winkley [1977].) However, during the cutoff period between 1929 and 1942, the dominant response was channel degradation. As shown in Figure 2-5, the stage reductions (degradation) at Vicksburg were in the range of 10 to $12 \mathrm{ft}$, while farther downstream at Natchez, the stage reductions were slightly less, in the 5 to $7 \mathrm{ft}$ range.

Table 2-3. Man-made meander cutoffs, 1929 - 1942 (adapted from Winkley [1977]).

\begin{tabular}{|l|c|c|c|}
\hline Cutoff Name & River Mile* & Year Opened & $\begin{array}{c}\text { Distance River } \\
\text { Shortened (miles) }\end{array}$ \\
\hline Hardin & 678 & 1942 & 16.9 \\
\hline Jackson & 628 & 1941 & 8.7 \\
\hline Sunflower & 625 & 1942 & 10.4 \\
\hline Caulk & 575 & 1937 & 15.2 \\
\hline Ashbrook & 549 & 1935 & 11.4 \\
\hline Tarpley & 541 & 1935 & 8.6 \\
\hline Leland* & 539 & 1933 & 9.8 \\
\hline Worthington & 514 & 1933 & 4.3 \\
\hline Sarah & 504 & 1936 & 5.3 \\
\hline Willow & 463 & 1934 & 7.7 \\
\hline Marshall & 448 & 1934 & 4.2 \\
\hline Diamond & 424 & 1933 & 12 \\
\hline Yucatan* & 408 & 1929 & 9.6 \\
\hline Rodney & 388 & 1936 & 5.9 \\
\hline Giles & 366 & 1933 & 11.1 \\
\hline Glasscock & 343 & 1933 & 10.8 \\
\hline & & Total & 1.9 \\
\hline$*$ Natural & & & \\
\hline
\end{tabular}

* Natural cutoffs. 
Figure 2-5. Specific gage records along the LMR (Winkley 1977).

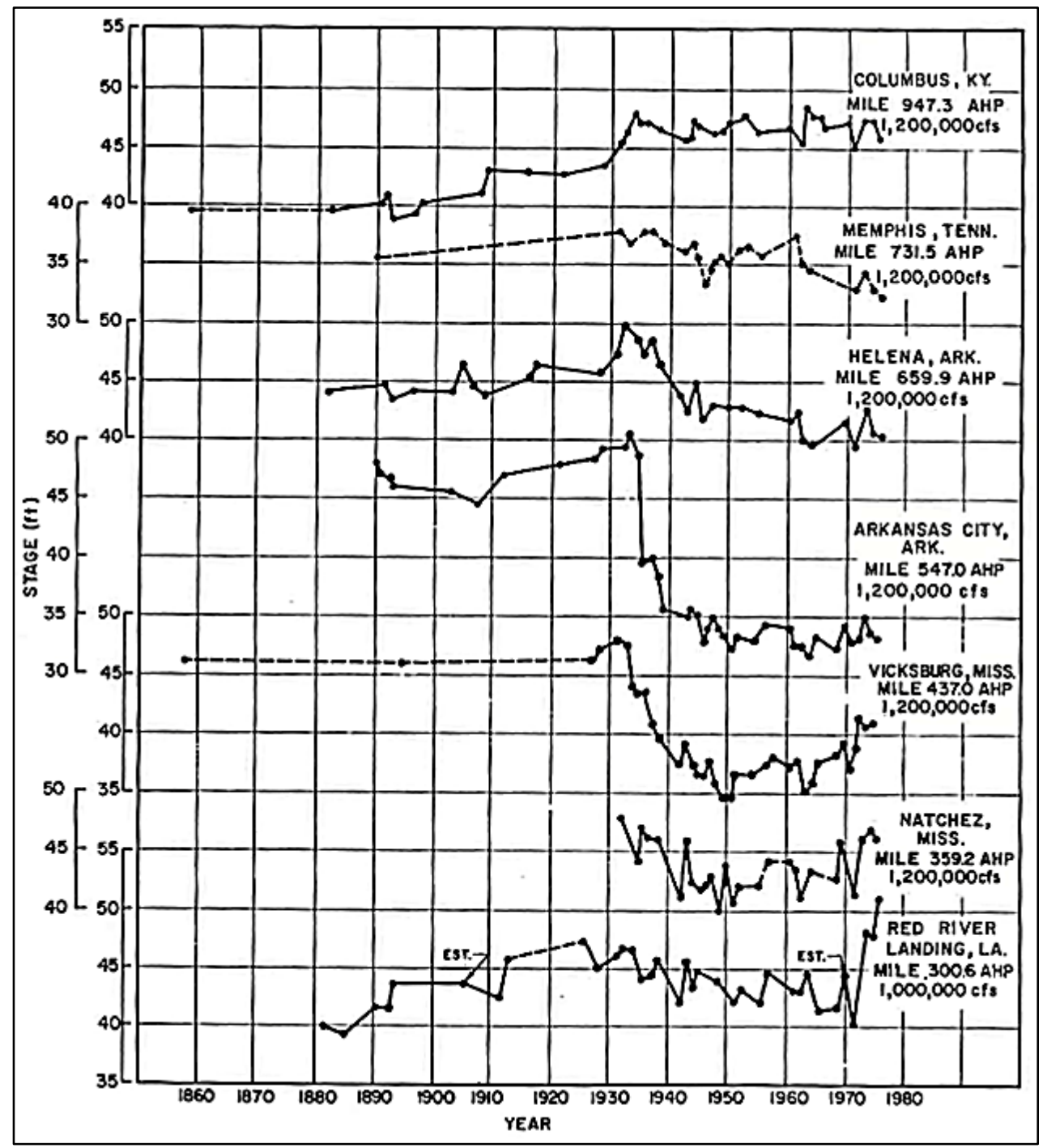

During the Cutoff Period, 40 man-made chute cutoffs were developed by dredging material to improve the river alignment and navigation. From 1932 to 1955, over 500,000 cubic yards (cy) of material were dredged between RM 942 and RM 357 to develop these chute cutoffs (Winkley 1977). Within the study reach (RM 487.2 to RM 317), eight chute cutoffs were developed that shortened the reach approximately 6 miles.

\subsection{Post-cutoff Period (1943 - present)}

This section discusses the geomorphic changes in the study reach that have occurred in the post-cutoff period (1943 - present). 


\subsubsection{Channel improvements (revetments, dikes, and dredging)}

The period from the mid-1940s through the mid-1960s was one of significant adjustments on the LMR as the river responded to the cutoffs. The cutoffs significantly increased the channel slope and stream power in the system. As a consequence of these changes, bank erosion increased as the channel attempted to regain channel length. It was during this initial period following the cutoffs that an aggressive revetment program was initiated in an attempt to stabilize channel alignments. The revetment construction history in the study reach is shown in Figures 2-6 and 2-7. As shown in Figure 3-6, there was an increase in revetment construction beginning in the 1940 s, reaching a peak in the 1950 s and 1960s. By the mid1960s, most of the major meander bends had been stabilized, thereby fixing the alignments in place. Subsequent construction was mostly associated with upstream and downstream extensions of existing revetments.

Figure 2-6. Revetment and dike construction timeline in the study reach.

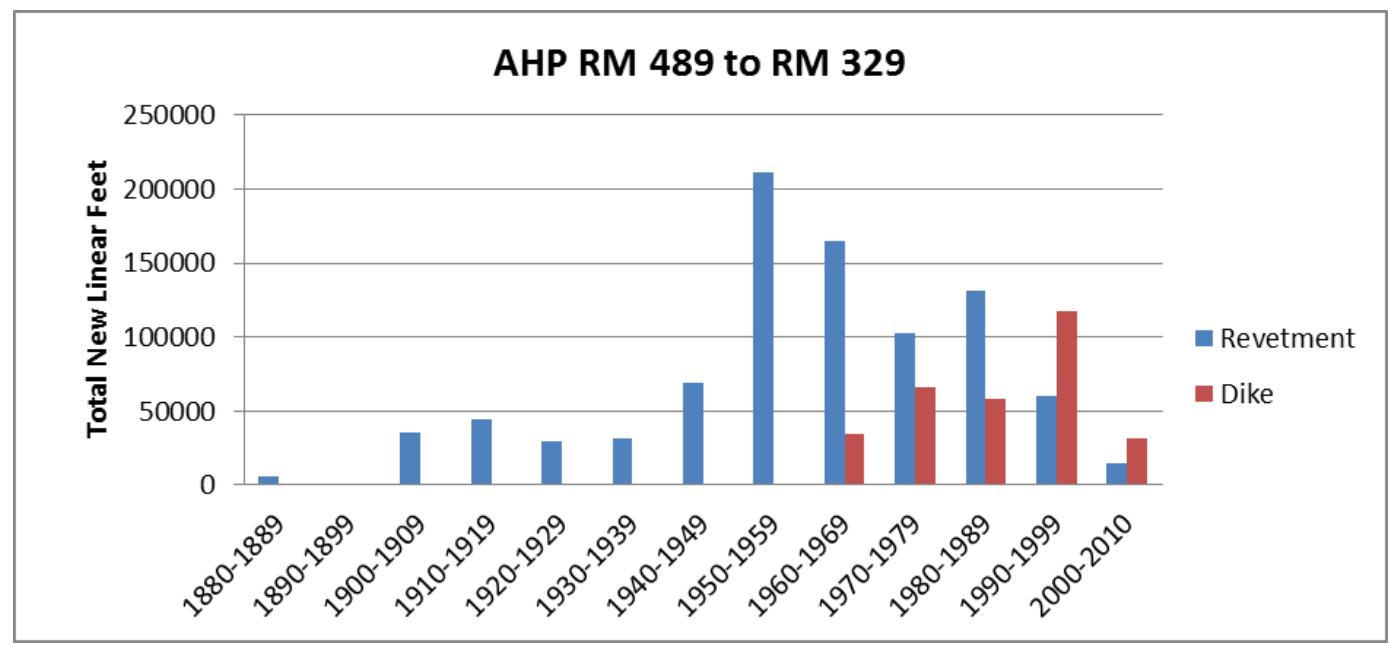


Figure 2-7. Total linear feet of revetments and dikes in study reach (by 10-mile increments).

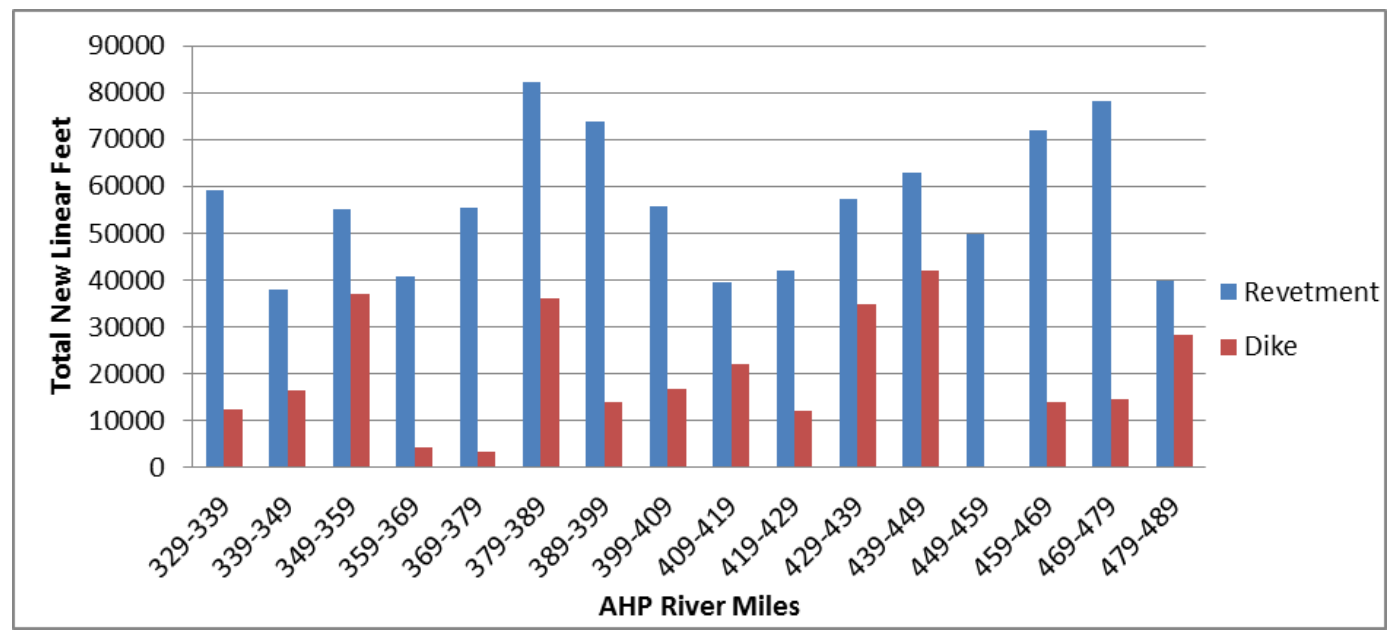

The revetment program has stabilized alignments in the river and significantly reduced bank caving in the river. Figure 2-8 shows the accumulated annual average bank caving volumes for the reach of river extending from just upstream of the Arkansas River to the ORCC during three time periods (Winkley 1973): 1877 - 1892, 1931 - 1942, and 1965 1972. These curves were developed by calculating the area associated with the bankline movement between surveys. An average bank height of $40 \mathrm{ft}$ was assumed for the volumetric computations. Using these curves, an estimate of the average annual bank caving volumes in the reach from Lake Providence to the ORCC was developed and is shown in Table 2-4. In Table 2-4, the data are presented for two time periods: (1) Pre-revetment Period, which represents the average of the two time periods $1877-1892$ and 1931 - 1942, and (2) Post-revetment Period. As shown in Table 2-4, the average annual bank caving volumes were reduced from approximately $350,000,000 \mathrm{cy} / \mathrm{year}$ in the pre-revetment period to approximately $30,000,000 \mathrm{cy} /$ year in the post-revetment period. This is a reduction in sediment delivery from the channel banks to the system of approximately $90 \%$. However, because the size distribution of these sediments was not reported, the significance of these sediment reductions on the morphological changes in the river system is not clear. Note that with the continuation of the revetment program since the 1970s, the volume of sediment delivered from bank caving has essentially been eliminated. 
Figure 2-8. Accumulated annual average bank caving volumes from the Arkansas River to the ORCC (Winkley 1973).

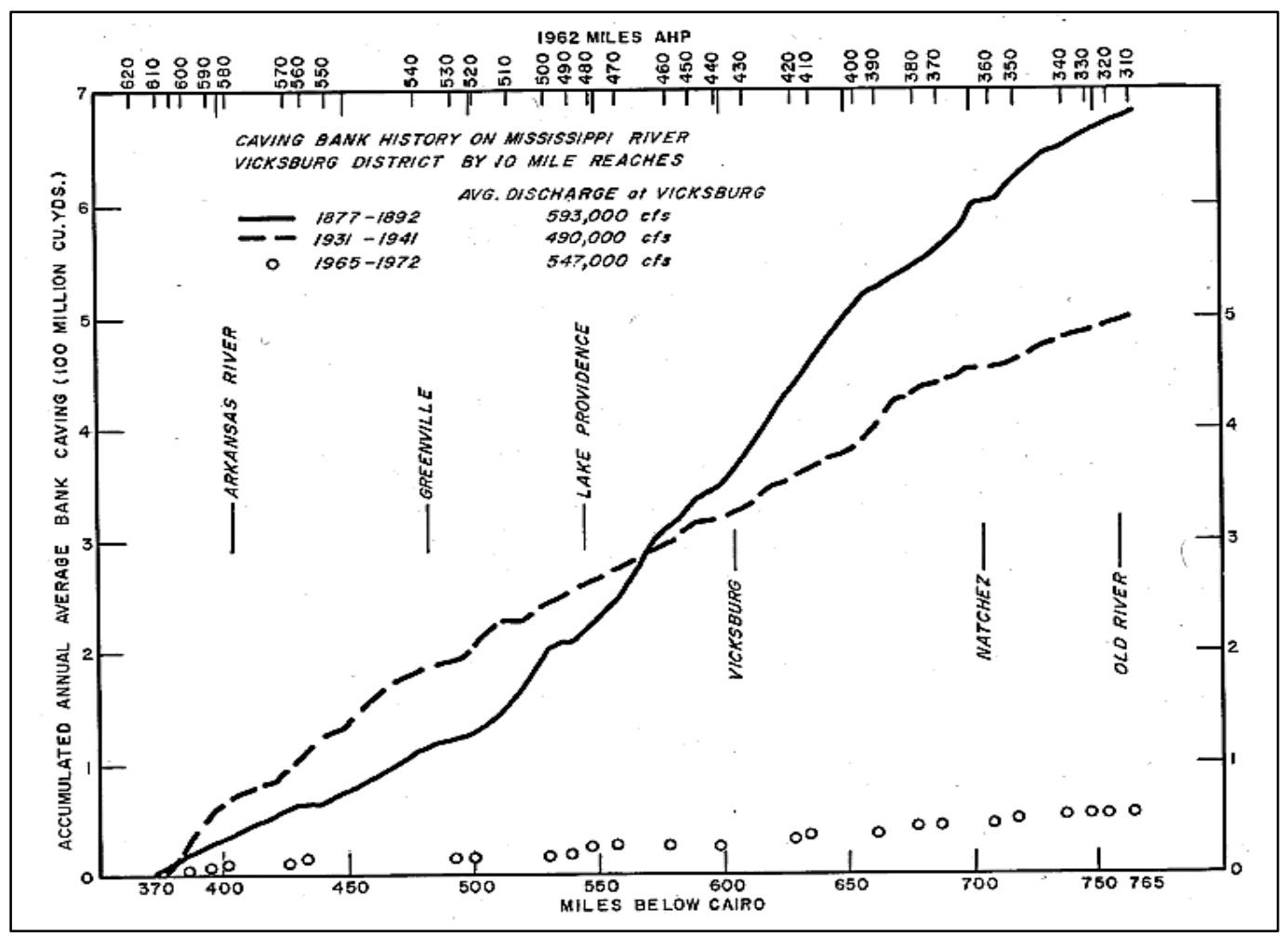

Table 2-4. Average annual bank caving volumes in the Lake Providence to Old River reach for the Pre- and Post-revetment Periods.

\begin{tabular}{|l|c|}
\hline Time Period & $\begin{array}{c}\text { Average Annual Bank Caving Volume } \\
\text { (cy/year) }\end{array}$ \\
\hline $\begin{array}{l}\text { Pre-revetment Period (average of } \\
\text { 1877-1892 and 1931-1942) }\end{array}$ & $350,000,000$ \\
\hline Post-revetment Period (1965-1972) & $30,000,000$ \\
\hline
\end{tabular}

The cutoffs also imposed a new alignment on the channel system that altered the historic crossing patterns in the river. These alignment changes combined with the increased sediment delivery from bed material upstream resulted in increased maintenance dredging throughout the system. Figure 2-9 shows the dramatic increases in maintenance dredging in the Memphis, Vicksburg, and New Orleans Districts from the late-1940s through the late-1960s. After 1970, the amount of maintenance dredging began a long-term decreasing trend. The reduced maintenance dredging was a result of two interrelated factors. The first was the revetment program, which imposed much better planform alignments with more orderly pool-crossing patterns. The next, and arguably the most important factor, was the construction of training structures (dikes). The purpose of 
these dike structures is to provide adequate navigation depths by constricting the channel width, closing off secondary channels and chutes to reduce divided flow, and adjusting channel alignment. The effectiveness of the dike systems in reducing the need for maintenance dredging is supported by the inverse relation between the amount of dredging and the cumulative length of constructed dikes (Figure 2-9).

Figure 2-9. Relationship between total linear feet of dikes and maintenance dredging in the Vicksburg, and Memphis Districts.

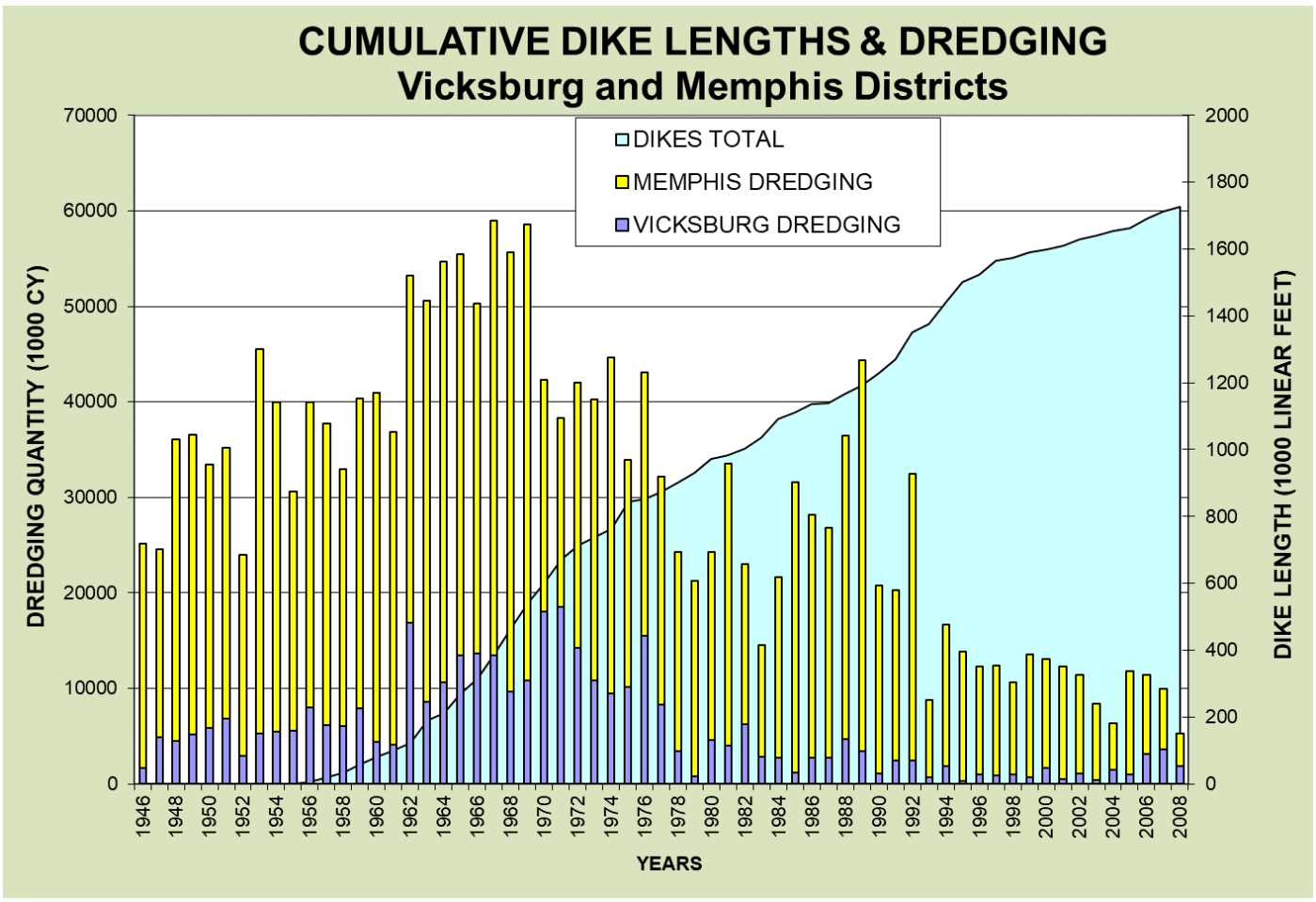

\subsubsection{Flow regime in the Post-cutoff Period}

The Post-cutoff Period covers a span of over 70 years, and as would be expected with such a long time period, there is considerable variability in the annual flow regimes as well as periodic cycles of low and high flows. Figure 2-10 shows how the average annual flow, based on computed daily discharge data, varied from 1901 through 2014. The daily discharge values from 1943 to 2014 were obtained from the Vicksburg District. However, daily discharge data were not available for the pre-1943 period. Therefore, the measured discharge data were used to develop discharge-stage relationships that were then coupled with the daily stage data to produce the daily discharge values prior to 1943. Note that there were time spans in the pre-1943 period where measurements were sparse or nonexistent, and, therefore there is more uncertainty in these data than in the post-1943 
data. However, the data were sufficient to produce a reasonable approximation of the average annual discharges during this period.

Of particular note in Figure 2-10 is the extreme low-water period between 1952 and 1972. This 20-year low-flow period ended abruptly with the 1973 flood. The average annual flow for this period $(1952-1972)$ was only approximately 526,000 cfs, which is considerably less than the pre-1952 or post-1972 periods, which had average annual flows of approximately $686,000 \mathrm{cfs}$ and $662,000 \mathrm{cfs}$, respectively. Alluvial streams adjust to the flow regime imposed upon them. Therefore, the extreme flows of the 1973 flood were forced upon a system that had adjusted to a 20-year low flow period. This may be a partial explanation for why the stage-discharge relationships shifted upward so abruptly during the 1973 flood.

Figure 2-10. Average annual discharges at Vicksburg.

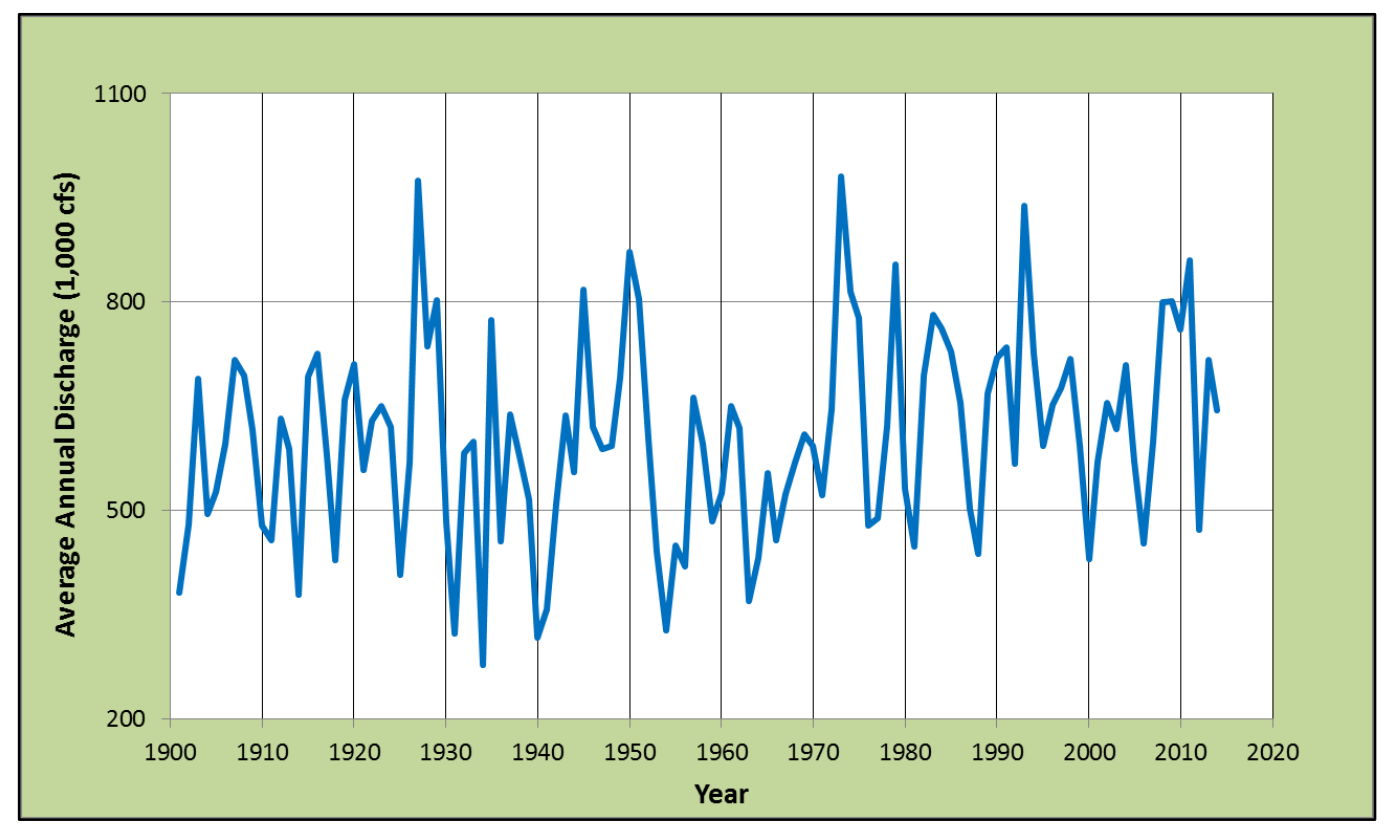

\subsubsection{Specific gage records}

Specific gage analysis is an effective tool used by river engineers and scientists to assess the historical behavior of rivers. Watson et al. (2013) provides a detailed description of the specific gage analysis. Fundamentally, a specific gage record is simply a plot of river stage versus time for a specific discharge. A specific gage record can be developed by one or two methods. The first is referred to as the rating curve method and the second as the direct step method. For this study, the rating curve method was selected. 
Specific gage records were developed at four stations in the study reach. Table 2-5 lists the location, station type, and period of record. The following is a brief discussion of the observed trends at each of the stations.

Table 2-5. Specific gage locations within the study reach.

\begin{tabular}{|l|c|l|l|c|}
\hline Station Name & $\begin{array}{c}\text { Location } \\
\text { (RM) }\end{array}$ & Station Type* & $\begin{array}{l}\text { Discharge } \\
\text { Station }\end{array}$ & $\begin{array}{c}\text { Period of } \\
\text { Record }\end{array}$ \\
\hline Lake Providence & 487.2 & Secondary & Vicksburg & $1906-2014$ \\
\hline Vicksburg & 435.7 & Primary & Vicksburg & $1903-2016$ \\
\hline St. Joseph & 396.4 & Secondary & Natchez & $1935-1996$ \\
\hline Natchez & 363.3 & Primary & Natchez & $1935-2016$ \\
\hline
\end{tabular}

* Primary stations collect flow and stage data, and secondary stations collect stage data only.

Lake Providence

The Lake Providence gage is a secondary station located at RM 487.2 AHP. Observed stages at Lake Providence were combined with discharges measured at Vicksburg (using a 1-day lag time) to generate the specific gage record. The period of record for the specific gage analysis extends from 1903 to 2014 (Figure 2-11). Bankfull stage is $37 \mathrm{ft}$ on the Lake Providence gage. The channel degradation, which began in the early-1930s as a result of the cutoff, continued through the late-1940s to early-1950s. Since the 1950s, there have been some fluctuations in stage, but overall stages have remained relatively stable.

\section{Vicksburg}

Vicksburg is a primary station located at RM 435.7 AHP. The period of record for the specific gage analysis extends from 1903 to 2016 (Figure 2-12). Bankfull stage is $43 \mathrm{ft}$ on the Vicksburg gage. An abrupt decrease in stages for all flows occurred during the early-1930s, and this decreasing trend continued throughout the 1940 s and early-1950s. Since then, stages for all flows greater than 200,000 cfs have fluctuated around what appears to be a generally increasing trend. In contrast, stages for a discharge of 200,000 cfs have been relatively stable since the $1950 \mathrm{Os}$. 
Figure 2-11. Specific gage record at Lake Providence, LA.

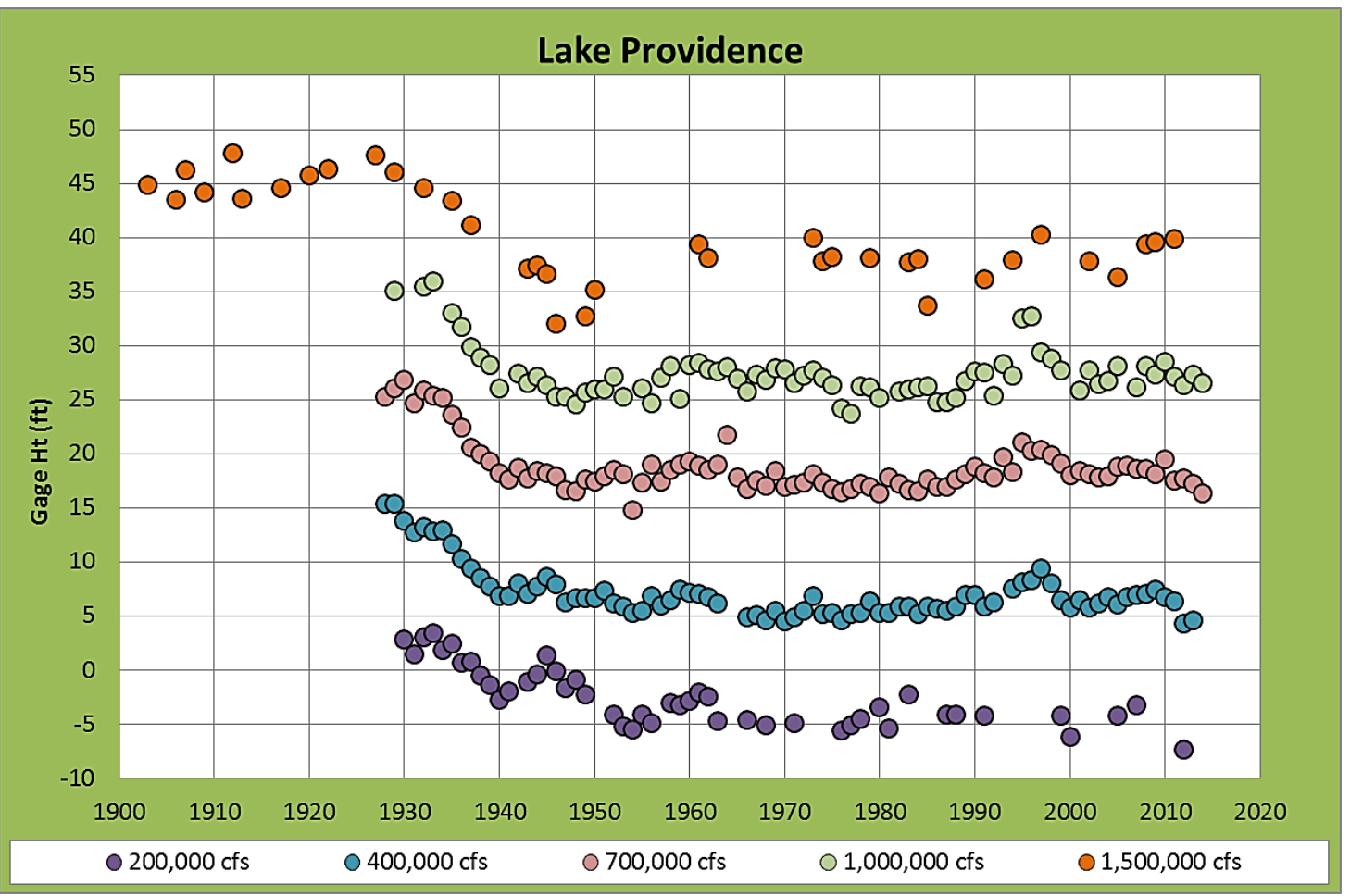

Figure 2-12. Specific gage record at Vicksburg, MS.

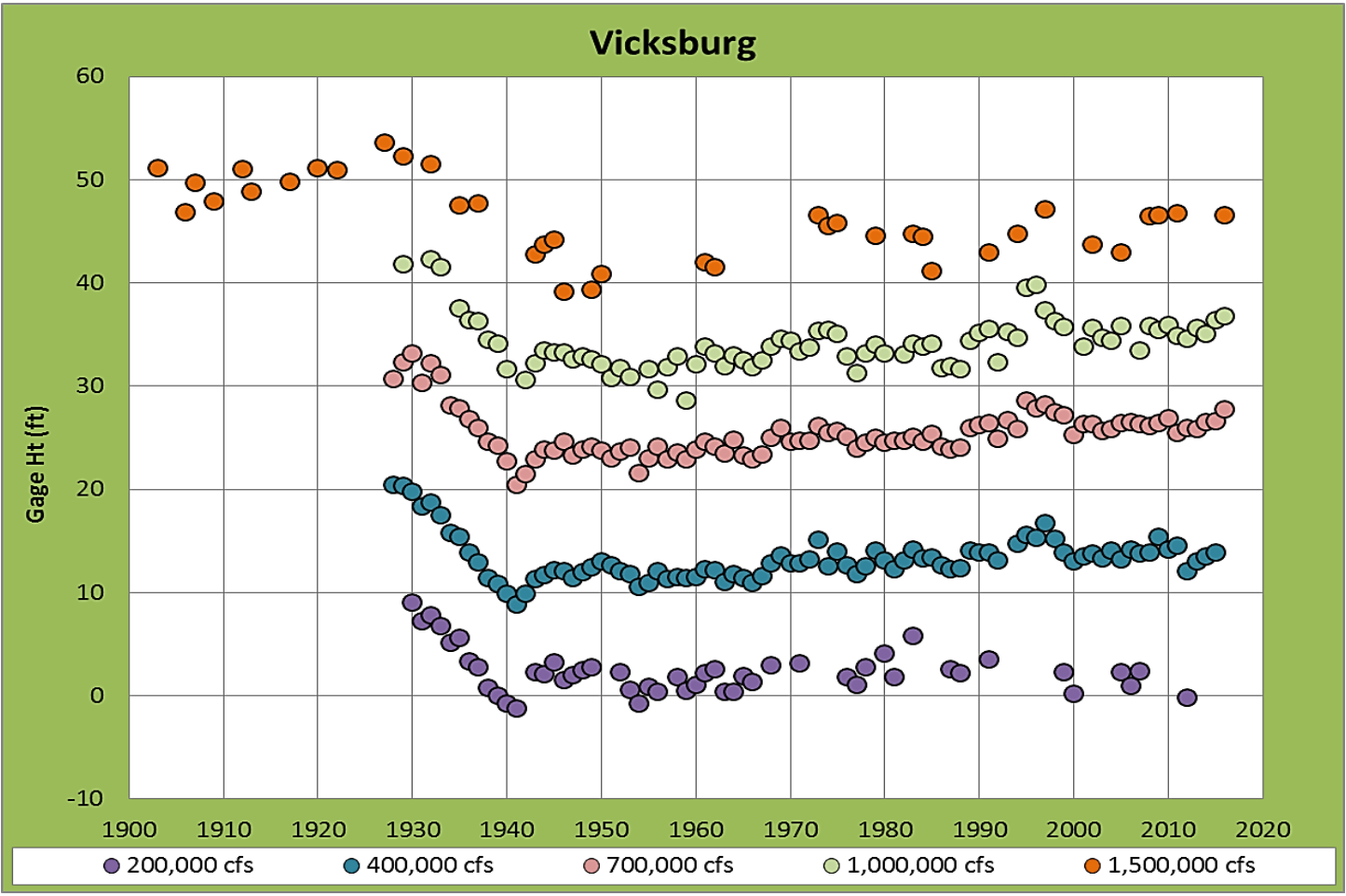




\section{St. Joseph}

St. Joseph is a secondary station located at RM 396.4 AHP. The specific gage record was developed by coupling daily stages observed at St.

Joseph with discharges measured at Natchez using a 1-day time lag. The period of record for the specific gage analysis extends from 1935 to 1996 (Figure 2-13). Bankfull stage is $40 \mathrm{ft}$ on the St. Joseph gage. As shown in Figure 2-13, a decreasing trend in stages began in the mid-1930s and persisted into the early-1940s. Between the mid-1940s and the end of the period of record in the mid-1990s, stages for all but the lowest discharge exhibited an increasing trend. Stages for $200,000 \mathrm{cfs}$ remained relatively stable.

Figure 2-13. Specific gage record at St. Joseph, LA.

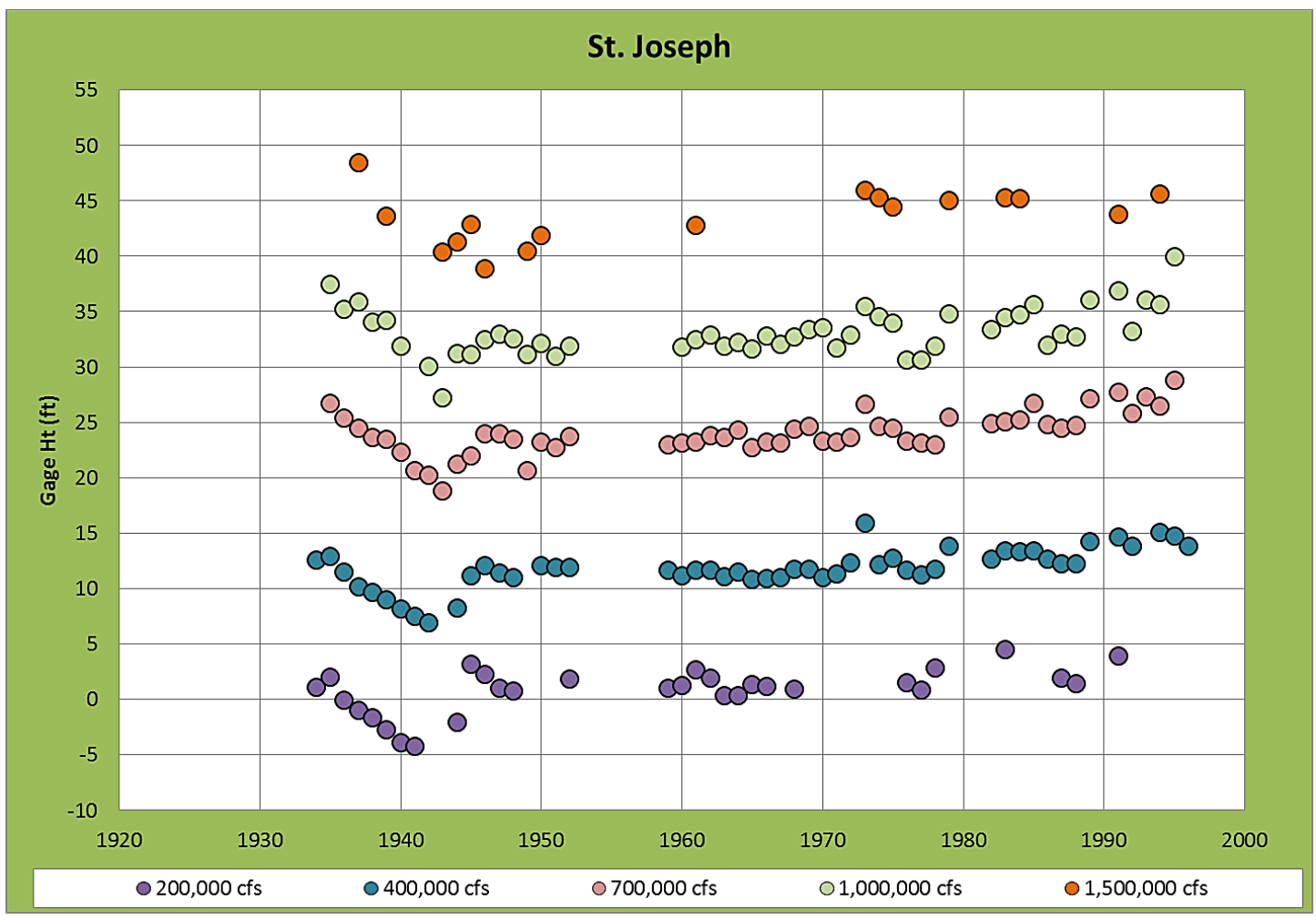

Natchez

Natchez is a primary station located at RM 363.3 AHP. The period of record for the specific gage analysis extends from 1935 to 2016 (Figure 2-14). Bankfull stage is $48 \mathrm{ft}$ on the Natchez gage. As shown in Figure 2-14, stages for all flows decreased abruptly in the late-1930s and continued to display a downward trend during the early-1940s. Since the 
mid-1940s, a general, increasing trend is evident in the stages associated with all selected flows.

Figure 2-14. Specific gage record at Natchez, MS.

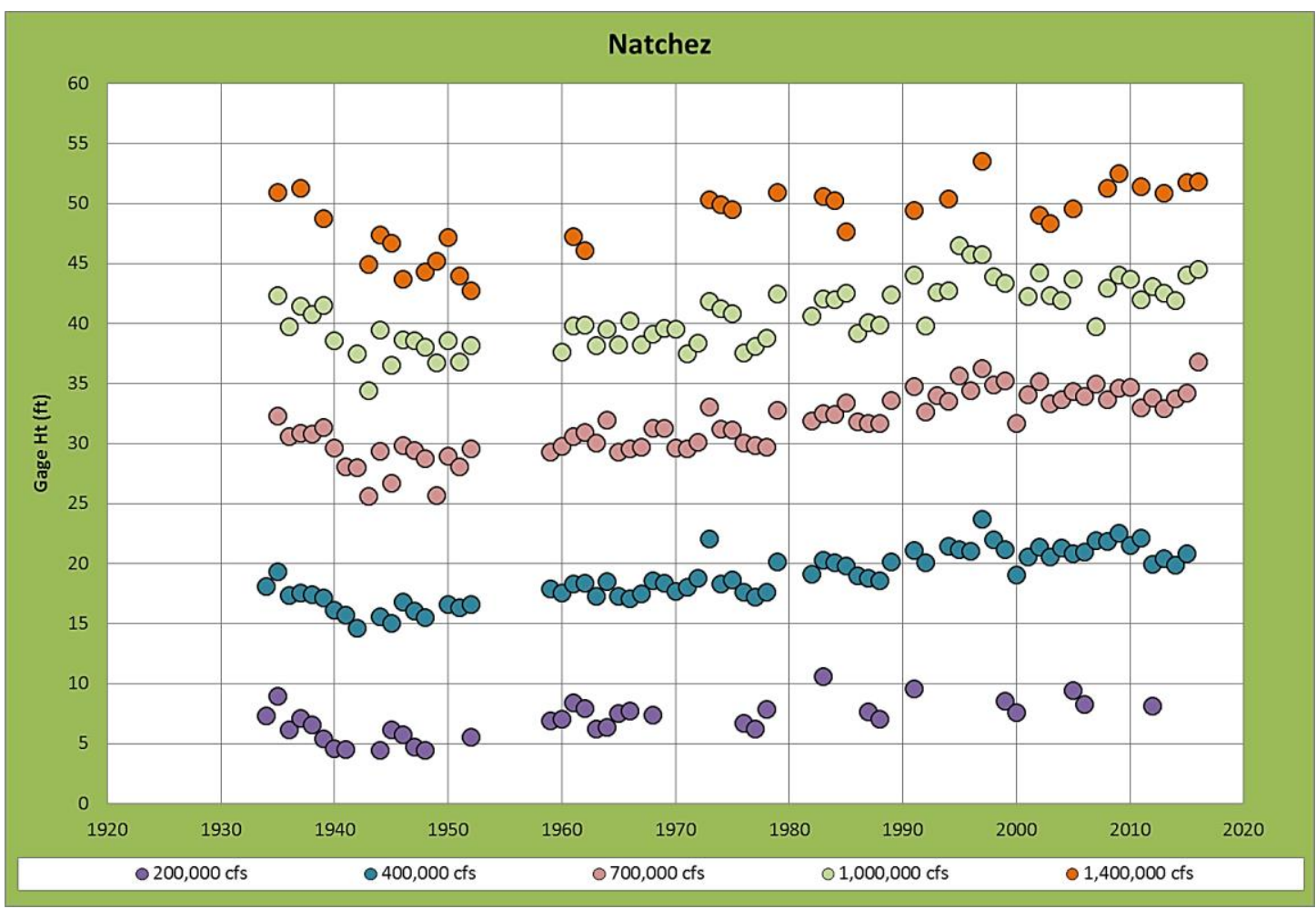

Specific gage summary

The study reach is responding in an expected manner following a series of meander cutoffs. At the upstream end of the reach, represented by the Lake Providence gage, the stages have been relatively stable since the early-1950s. Moving farther downstream, the gages (Vicksburg, St. Joseph, and Natchez) become progressively more aggradational. This suggests that the reach from Lake Providence to Vicksburg may be a transition reach between dynamic equilibrium and the aggradational trends that exist farther downstream.

\subsubsection{Water surface slope trends}

Water surface slope is an important parameter that provides a representation of the energy in a channel system. Slope is closely associated with the sediment transport capacity, and therefore any changes in channel slope can be used to infer morphologic changes in a channel system. Slope trends on the LMR are extremely important 
because of the dramatic increases that occurred immediately after the meander cutoffs. Tracking these slope changes in the Pre- and Post-cutoff Periods provides valuable insight into the morphology of the study reach.

Water surface slopes were calculated between the following sub-reaches:

(1) Lake Providence to Vicksburg; (2) Vicksburg to St. Joseph;

(3) St. Joseph to Natchez; and (4) Vicksburg to Natchez. Daily water surface slopes were calculated using daily stage data and the distance (in miles) between the gaging stations. Average annual slope values were then calculated for each year.

\section{Lake Providence to Vicksburg}

Figure 2-15 shows the trends in average annual water surface slopes for the Lake Providence to Vicksburg reach. Table 2-6 presents the time periods, distances between the gages, and description of events that caused the distance change (cutoffs, meander activity, gage location change, etc.) in the Lake Providence to Vicksburg Reach. Table 2-7 shows the average slope values at various time periods in the reach.

Figure 2-15. Average annual water surface slopes for the Lake Providence to Vicksburg reach.

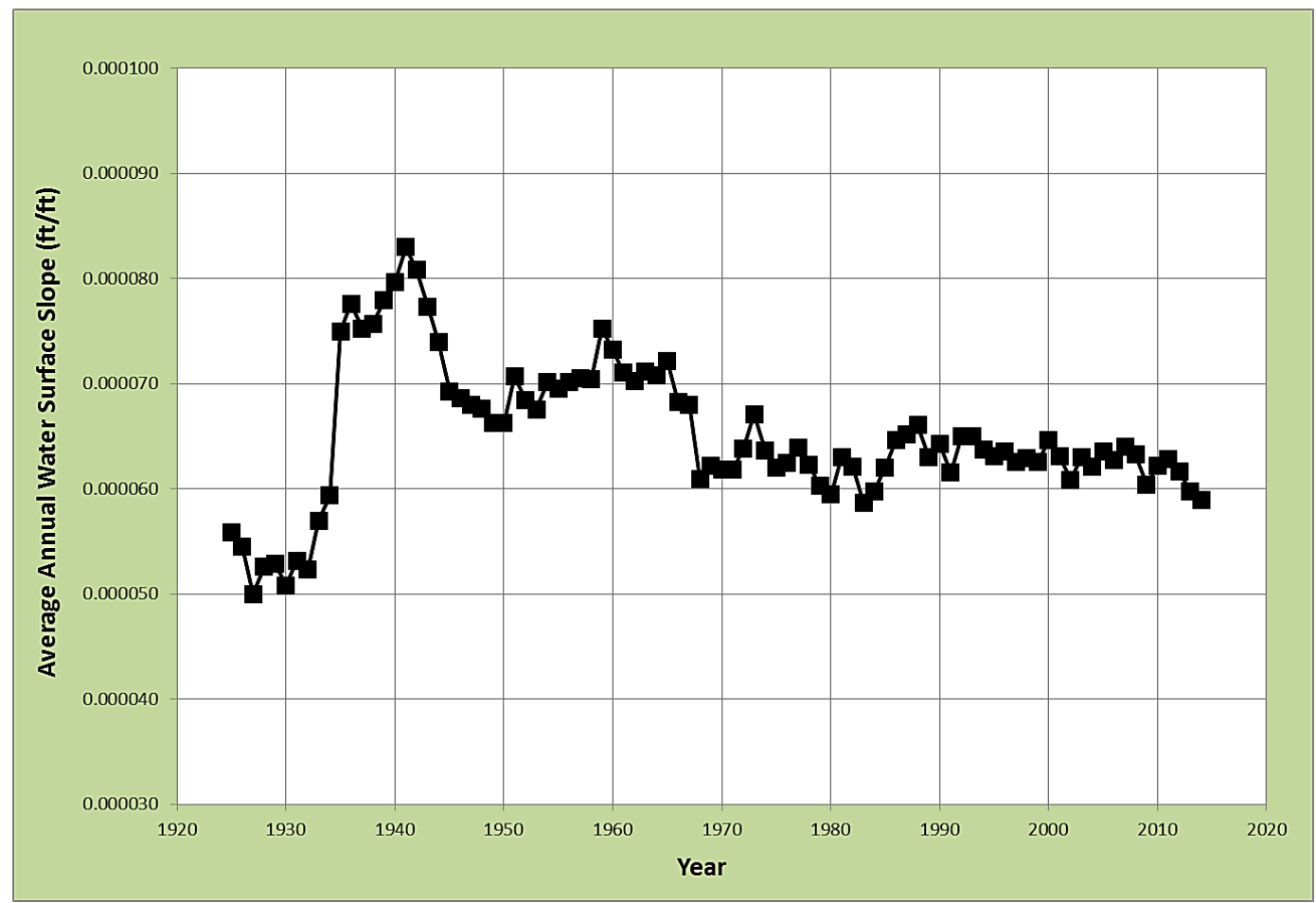


Table 2-6. Period of record and reach length data for the Lake Providence to Vicksburg reach.

\begin{tabular}{|l|c|l|}
\hline Period & $\begin{array}{c}\text { Reach Length } \\
\text { (miles) }\end{array}$ & Description \\
\hline Pre-1935 & 63.2 & This period reflects the Pre-cutoff conditions. \\
\hline 1935-1964 & 49.5 & This period reflects the Marshall and Willow cutoffs in 1935. \\
\hline 1965-1976 & 48.4 & $\begin{array}{l}\text { This period reflects the gage change at Lake Providence, which } \\
\text { shifted the gage downstream approximately 3.8 miles. It also } \\
\text { reflects the growth along the outside of Cottonwood Bar. } \\
\text { Therefore, the reduction in length is only slightly less than 1 mile. }\end{array}$ \\
\hline 1977-1984 & 49.7 & $\begin{array}{l}\text { This period reflects the gage location change at Vicksburg } \\
\text { downstream approximately 1.3 miles. }\end{array}$ \\
\hline 1985-2014 & 48.2 & This period reflects the realignment at Cottonwood Bar in 1985. \\
\hline
\end{tabular}

Table 2-7. Average annual water surface slopes for three time periods in the Lake Providence to Vicksburg reach.

\begin{tabular}{|c|c|c|c|c|}
\hline \multicolumn{5}{|c|}{ Average Annual Water Surface Slope } \\
\hline $\begin{array}{l}\text { Time Period No. } \\
1 \\
\text { Pre-cutoff } \\
\text { Period (prior to } \\
\text { mid-1930s) }\end{array}$ & $\begin{array}{l}\text { Time Period } \\
\text { No.2 } \\
\text { (mid-1930s to } \\
\text { mid-1940s) }\end{array}$ & $\begin{array}{l}\text { Time Period No. } 3 \\
\text { Post-cutoff Period } \\
\text { (mid 1980s to } \\
\text { present) }\end{array}$ & $\begin{array}{l}\text { Percent } \\
\text { Increase } \\
\text { between } \\
\text { Periods No. } \\
1 \text { and No. } 2\end{array}$ & $\begin{array}{l}\text { Percent } \\
\text { Increase } \\
\text { between } \\
\text { Periods No. } 1 \\
\text { and No. } 3\end{array}$ \\
\hline 0.000054 & 0.000078 & 0.000063 & $44 \%$ & $16 \%$ \\
\hline
\end{tabular}

Beginning in the mid-1930s and continuing through the mid-1940s, there was a dramatic increase in slope in the Lake Providence to Vicksburg reach as a result of the cutoffs (Figure 2-15). During this period, slopes increased from approximately 0.000054 to 0.000078 , an increase of approximately 44\% (Table 2-7). From the mid-1940s through the mid-1970s to early1980 , the slopes fluctuated but generally exhibited a decreasing trend. Since the early-1980s, the slopes have been relative stable, with an average slope of approximately 0.000063. As shown in Table 2-7, the present-day slopes (early-1980s to present) are approximately $16 \%$ higher than the Pre-cutoff slopes.

\section{Vicksburg to St. Joseph}

The changes in the average annual water surface slopes for the Vicksburg to St. Joseph reach are shown in Figure 2-16. Reach characteristics are shown in Table 2-8 and average Pre- and Post-cutoff slopes are shown in Table 2-9. Note that there are no data after 1996 due to the discontinuance of the St. Joseph gage. 
Figure 2-16. Water surface slope trends in the Vicksburg to St. Joseph reach.

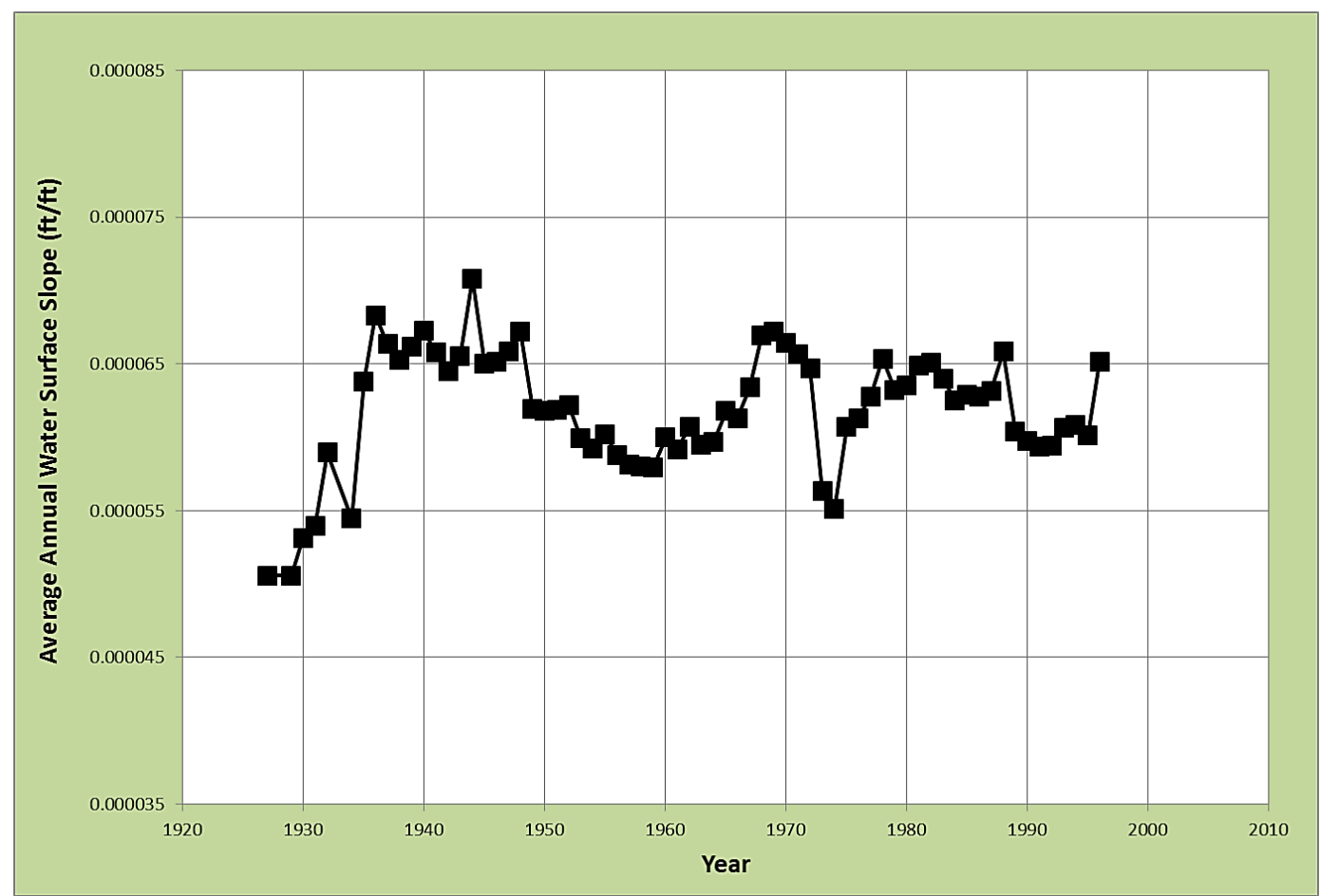

Table 2-8. Period of record and reach length data for the Vicksburg to St. Joseph reach.

\begin{tabular}{|l|c|l|}
\hline Period & Length (miles) & Description \\
\hline Pre-1932 & 68.4 & This period reflects the Pre-cutoff reach length. \\
\hline 1932-1934 & 57 & $\begin{array}{l}\text { This period reflects the Yucatan cutoff in 1929, } \\
\text { which became effective around 1932. }\end{array}$ \\
\hline 1935-1944 & 43.5 & $\begin{array}{l}\text { This period reflects the Diamond cutoff, which } \\
\text { became effective in 1935. }\end{array}$ \\
\hline 1945-1974 & 39.5 to 43.3 & $\begin{array}{l}\text { The initial length in 1945 was 39.5 miles, which } \\
\text { reflected the movement of the St. Joseph gage 3 } \\
\text { miles upstream. By 1974, the reach had increased in } \\
\text { length to 43.3 miles due to meander migration. A } \\
\text { linear interpolation was used for the intervening } \\
\text { years between 1945 and 1974. }\end{array}$ \\
\hline 1975-1976 & 40.8 & $\begin{array}{l}\text { The Togo chute developed approximately 1975, } \\
\text { which shortened the reach about 2.5 miles. }\end{array}$ \\
\hline 1977-1996 & 39.5 & $\begin{array}{l}\text { This period reflects a reduction in length of 1.3 miles } \\
\text { due to the movement of the Vicksburg gage. }\end{array}$ \\
\hline
\end{tabular}


Table 2-9. Average annual water surface slopes for three time periods in the Vicksburg to St. Joseph reach.

\begin{tabular}{|c|c|c|c|c|}
\hline \multicolumn{5}{|c|}{ Average Annual Water Surface Slope } \\
\hline $\begin{array}{l}\text { Time Period No. } 1 \\
\text { Pre-cutoff Period } \\
\text { (prior to mid- } \\
\text { 1930s) }\end{array}$ & $\begin{array}{l}\text { Time Period } \\
\text { No.2 } \\
\text { (mid-1930s } \\
\text { to mid- } \\
\text { 1940s) }\end{array}$ & $\begin{array}{l}\text { Time Period No. } 3 \\
\text { Post-cutoff Period } \\
\text { (mid-1980s to } \\
\text { 1995) }\end{array}$ & $\begin{array}{l}\text { Percent } \\
\text { Increase } \\
\text { between } \\
\text { Periods No.1 } \\
\text { and No.2 }\end{array}$ & $\begin{array}{l}\text { Percent } \\
\text { Increase } \\
\text { between } \\
\text { Periods No.1 } \\
\text { and No.3 }\end{array}$ \\
\hline 0.000054 & 0.000066 & 0.000063 & $24 \%$ & $17 \%$ \\
\hline
\end{tabular}

Water surface slopes increased dramatically between the mid-1930s and the mid-1940s immediately after the artificial cutoffs. As shown in Table 2-9, channel slopes were approximately $24 \%$ higher immediately after the cutoffs (mid-1930s to mid-1940s) compared to the Pre-cutoff slopes. After the mid-1940s, the slopes began a decreasing trend, which generally continued until the early 1960s. From the early-1960s to 1995, channel slope exhibited alternating periods of increasing and decreasing trends but remained within an approximate range between 0.00006 and 0.000067 with an average slope of approximately 0.000063. Comparison of the Precutoff and Post-cutoff (mid-1980s to 1995) data shows that the Post-cutoff slopes are still approximately $17 \%$ higher than the Pre-cutoff slopes (Table 2.9).

\section{St. Joseph to Natchez}

The trends in water surface slope for the St. Joseph to Natchez reach are shown in Figure 2-17. The period of record and reach length data for this reach are shown in Table 2-10. Table 2-11 provides the slope changes in the Pre- and Post-cutoff Periods. Again, the period of record only extends to 1996 due to the discontinuance of the St. Joseph gage.

Following the cutoffs in the mid-1930s, the slopes in the study reach increased abruptly reaching a peak in approximately 1936. After this, the slopes decreased until approximately 1940 when the slope began to increase again. The slopes remained elevated until the mid-1950s when they decreased again. These initial slope increases, which persisted through the mid-1950s, were approximately $45 \%$ higher than the Precutoff slopes (Table 2-10). Since the mid-1960s up to 1996, the slopes have remained relatively stable with an average slope of approximately 0.000053 , which is approximately $29 \%$ higher than the Pre-cutoff slopes. 
Figure 2-17. Water surface slope trends in the St. Joseph reach to Natchez.

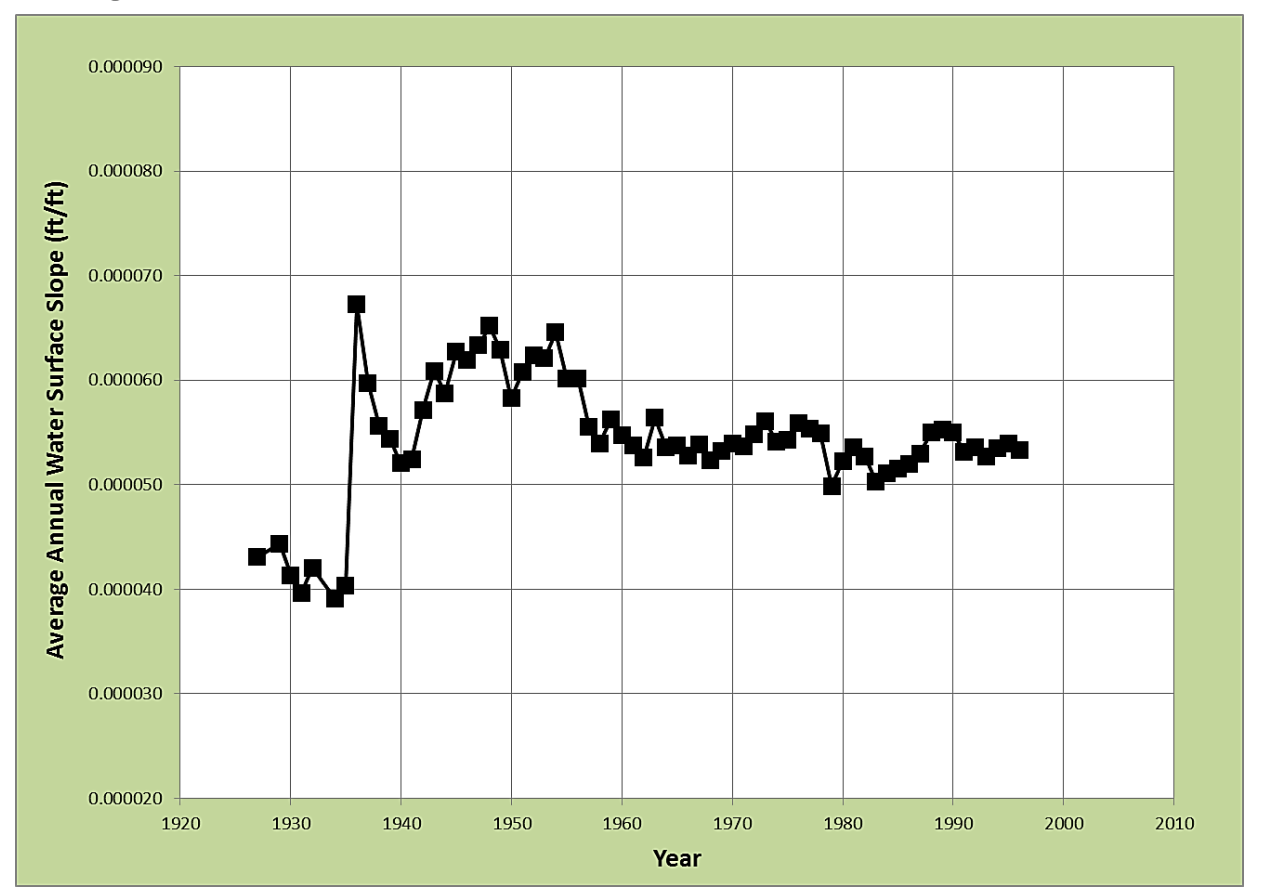

Table 2-10. Period of record and reach length data for the St. Joseph to Natchez reach.

\begin{tabular}{|c|c|l|}
\hline Period & Length (miles) & Description \\
\hline $1927-1935$ & 47.8 & This period reflects the Pre-cutoff reach length. \\
\hline $1936-1940$ & 28.4 & $\begin{array}{l}\text { This period reflects the Giles and Rodney cutoffs, } \\
\text { which became effective in 1935 and 1936, } \\
\text { respectively. The year 1936 was used to represent } \\
\text { both for these calculations. }\end{array}$ \\
\hline $1941-1944$ & 28.7 & $\begin{array}{l}\text { The Natchez gage was moved approximately 0.3 mile } \\
\text { downstream in 1941 }\end{array}$ \\
\hline $1945-1996$ & 33 & $\begin{array}{l}\text { In 1945, the gage at St. Joseph was moved upstream } \\
\text { approximately 4.3 miles. }\end{array}$ \\
\hline
\end{tabular}

Table 2-11. Average annual water surface slopes for three time periods in the St. Joseph to Natchez reach.

\begin{tabular}{|c|c|c|c|c|}
\hline \multicolumn{5}{|c|}{ Average Annual Water Surface Slope } \\
\hline $\begin{array}{l}\text { Time Period } \\
\text { No. } 1 \\
\text { Pre-cutoff } \\
\text { Period (prior to } \\
\text { mid-1930s) }\end{array}$ & $\begin{array}{l}\text { Time Period } \\
\text { No.2 } \\
\text { (mid-1930s to } \\
\text { mid-1940s) }\end{array}$ & $\begin{array}{l}\text { Time Period } \\
\text { No. } 3 \\
\text { Post-cutoff } \\
\text { Period } \\
\text { (mid-1960s to } \\
\text { 1995) }\end{array}$ & $\begin{array}{l}\text { Percent } \\
\text { Increase } \\
\text { between } \\
\text { Periods No.1 } \\
\text { and No.2 }\end{array}$ & $\begin{array}{l}\text { Percent } \\
\text { Increase } \\
\text { between } \\
\text { Periods No.1 } \\
\text { and No.3 }\end{array}$ \\
\hline 0.000041 & 0.000060 & 0.000053 & $45 \%$ & $29 \%$ \\
\hline
\end{tabular}




\section{Vicksburg to Natchez}

The previous two sections discussed the slope trends for the Vicksburg to St. Joseph and St. Joseph to Natchez reaches. However, as discussed, the period of record in these two reaches only extended through 1996 due to the discontinuance of the St. Joseph gage. The advantage of considering the Vicksburg to Natchez reach is that is has a much longer period of record. However, it must be recognized that the slope calculations cover a much longer reach and therefore represent a somewhat more broad-scale view of the system.

Figure 2-18 shows the slope trends for the Vicksburg to Natchez reach. Table 2-12 describes the time periods, distances between the gages, and description of events that caused the distance change (cutoffs, meander activity, gage location change, etc.) in the Vicksburg to Natchez Reach. Table 2-13 shows the average slope values at various time periods in the reach.

Figure 2-18. Water surface slope trends in the Vicksburg to Natchez Reach.

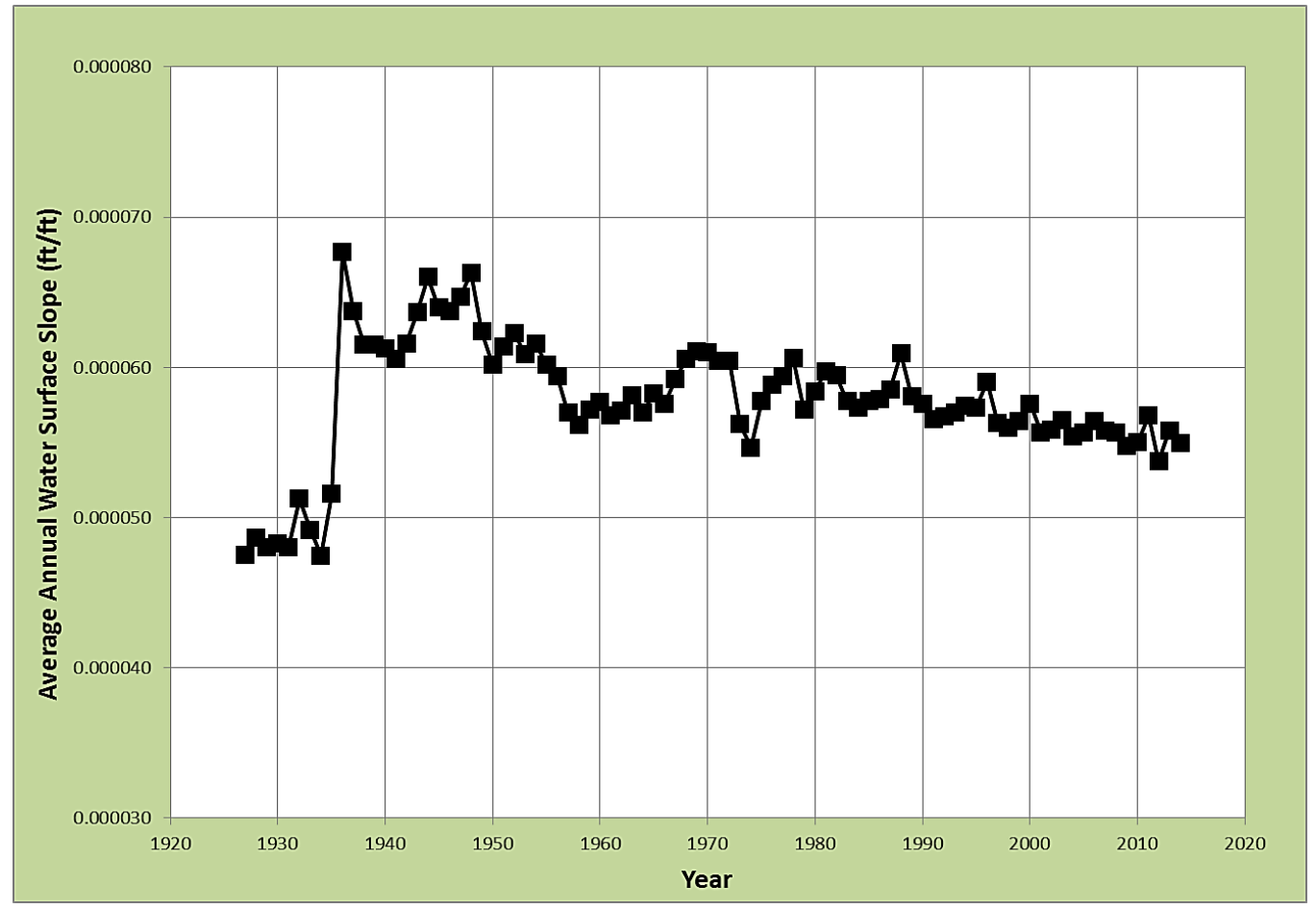


Table 2-12. Period of record and reach length data for the Vicksburg to Natchez reach.

\begin{tabular}{|l|c|l|}
\hline Period & $\begin{array}{c}\text { Length } \\
\text { (miles) }\end{array}$ & Description \\
\hline Pre-1932 & 116.2 & This period reflects the Pre-cutoff conditions. \\
\hline $1932-1934$ & 104 & $\begin{array}{l}\text { This period reflects the Yucatan cutoff in 1929, which } \\
\text { became effective approximately 1932. }\end{array}$ \\
\hline 1935 & 91.3 & This period reflects the Diamond cutoff. \\
\hline $1936-1940$ & 71.9 & $\begin{array}{l}\text { This period reflects the Giles and Rodney cutoffs which } \\
\text { became effective in 1935 and 1936, respectively. The year }\end{array}$ \\
\hline $1941-1944$ & 72.2 & $\begin{array}{l}\text { The Natchez gage was moved approximately 0.3 mile } \\
\text { downstream in 1941. }\end{array}$ \\
\hline 1945-1976 & 73.8 & $\begin{array}{l}\text { In 1945, the gage at St. Joseph was moved upstream } \\
\text { approximately 4.3 miles. Also, between 1945 and 1976, the } \\
\text { channel length increased from 39.5 miles to 43.5 miles } \\
\text { through meandering between Vicksburg and St. Joseph. }\end{array}$ \\
\hline 1977-2014 & 72.5 & $\begin{array}{l}\text { The Vicksburg gage was moved downstream approximately } \\
\text { 1.3 miles in 1977. }\end{array}$ \\
\hline
\end{tabular}

Table 2-13. Average annual water surface slopes for three time periods in the Vicksburg to Natchez reach.

\begin{tabular}{|l|l|l|l|l|}
\hline \multicolumn{5}{|c|}{ Average Annual Water Surface Slope } \\
\hline $\begin{array}{l}\text { Time Period No. 1 } \\
\begin{array}{l}\text { Pre-cutoff Period } \\
\text { (prior to mid- } \\
\text { 1930s) }\end{array}\end{array}$ & $\begin{array}{l}\text { Time Period No.2 } \\
\text { (mid-1930s to } \\
\text { late-1940s) }\end{array}$ & $\begin{array}{l}\text { Time Period No. 3 } \\
\text { Post-cutoff Period } \\
\text { (Late 1980s - } \\
\text { present) }\end{array}$ & $\begin{array}{l}\text { Percent } \\
\text { Increase } \\
\text { between } \\
\text { Periods No.1 } \\
\text { and No.2 }\end{array}$ & $\begin{array}{l}\text { Percent } \\
\text { Increase } \\
\text { between } \\
\text { Periods No.1 } \\
\text { and No.3 }\end{array}$ \\
\hline 0.000049 & 0.000064 & 0.000056 & $31 \%$ & $16 \%$ \\
\hline
\end{tabular}

The Pre-cutoff slopes in this reach averaged approximately 0.000049. In the mid-1930s, the slopes increased and remained elevated through the late-1940s with an average slope of approximately 0.000064 (Figure 2-18). This was an increase of approximately $31 \%$ relative to the Pre-cutoff slopes (Table 2-13). Between the late-1940s and late-1960s, there was a decreasing trend in the slopes. From the late-1950s through the late-1980s, the slopes exhibited some fluctuations but were overall relatively stable. Since the late1980 s, the slopes appear to have been on a slightly decreasing trend with an average slope of approximately 0.000056. This decreasing slope trend likely reflects the higher aggradation rates at Natchez as compared to Vicksburg. As shown in Table 2-13, the present-day slopes (late-1980s to present) are approximately $16 \%$ higher than the slopes in the Pre-cutoff Period. 


\section{Slope summary}

The artificial cutoffs in the 1930 s and early-1940s triggered substantial geomorphic change in the study reach. Initial increases in water surface slopes ranged from approximately $24 \%$ to $45 \%$. These increases in slope increased sediment transport capacity significantly, resulting in channel degradation throughout the reach. Although the slopes have decreased from their initial peak conditions immediately after the cutoffs, the present-day slopes in the study reach are still higher (generally approximately $17 \%$ ) than in the Pre-cutoff Period.

\subsubsection{Stage duration changes}

Stage duration curves were developed at the four major gaging stations in the study reach: Lake Providence, Vicksburg, St. Joseph, and Natchez. Although this section is primarily focused on the Post-cutoff Period, it is necessary to include some Pre-cutoff data as well, to place the present-day stage duration regime in a historical context. Stage duration data were developed for the five time periods shown in Table 2-14. Table 2-14 also lists the number of years of record in each time period and the average daily discharge for that period. The average daily discharge data were developed from the daily discharge data at the Vicksburg gage.

Table 2-14. Time periods used in the development of the stage duration curves.

\begin{tabular}{|c|c|c|}
\hline Period & Number of years & Average Daily flow (cfs) \\
\hline $1901-1921$ & 20 & $575,800 \mathrm{cfs}$ \\
\hline $1922-1944$ & 22 & $565,200 \mathrm{cfs}$ \\
\hline $1945-1972$ & 27 & $573,000 \mathrm{cfs}$ \\
\hline $1973-1993$ & 20 & $676,000 \mathrm{cfs}$ \\
\hline $1994-2014$ & 20 & $648,000 \mathrm{cfs}$ \\
\hline
\end{tabular}

Note that the two post-1973 time periods in Table 2-14 have similar average daily discharges. However, the flows in the pre-1973 periods are much smaller. This introduces some uncertainty when making comparisons between time periods. For this reason, the stage duration data were developed using two different approaches. The first was a straight calculation using all the data within the time period. This method uses all the data in the time period and therefore is a good representation of the actual flow regime that was experienced during that period. However, as noted there may be problems when trying to make relative 
comparisons to other time periods due to the variability in flows. The second approach is a flow-adjusted stage duration curve that selects specific years within each time period that produce approximately equal average daily flows for all time periods. Table 2-15 lists the selected years in each time period. As shown in Table 2-15, the average daily flows for the time periods are all within a few percent of each other. Using this approach reduces the number of years in each time period. However, it removes the uncertainty associated with varying flow regimes between the time periods and therefore allows for an unbiased comparison of stage duration changes through time.

Table 2-15. Selected years with similar average daily discharges.

\begin{tabular}{|c|c|c|c|c|c|c|c|c|c|}
\hline \multicolumn{10}{|c|}{ Average Daily Discharge (cfs) } \\
\hline $1901-1921$ & $1922-1944$ & $1945-1972$ & $1973-1993$ & $1994-2014$ \\
\hline 1911 & 456,705 & 1936 & 455,442 & 1953 & 439,710 & 1988 & 439,128 & 2000 & 432,139 \\
\hline 1902 & 480,372 & 1930 & 482,734 & 1959 & 484,323 & 1976 & 479,923 & 2012 & 474,121 \\
\hline 1906 & 596,341 & 1926 & 568,322 & 1968 & 570,279 & 1992 & 569,330 & 2005 & 569,863 \\
\hline 1909 & 615,778 & 1924 & 620,727 & 1946 & 620,178 & 1978 & 620,901 & 2003 & 616,513 \\
\hline 1919 & 659,742 & 1923 & 650,196 & 1957 & 661,795 & 1989 & 668,202 & 1997 & 672,815 \\
\hline 1920 & 710,853 & 1928 & 736,228 & 1949 & 690,756 & 1982 & 694,636 & 1998 & 707,875 \\
\hline 1907 & 716,989 & 1935 & 773,945 & 1945 & 817,137 & 1974 & 814,748 & 2008 & 801,290 \\
\hline 1916 & 725,102 & 1929 & 802,415 & 1950 & 872,071 & 1979 & 853,455 & 2011 & 857,621 \\
\hline Average & 620,235 & Average & 636,251 & Average & 644,531 & Average & 642,540 & Average & 641,530 \\
\hline
\end{tabular}

Lake Providence

The stage duration curve at Lake Providence is shown in Figure 2-19. Examination of these curves indicates that stages prior to 1944 were generally higher than in the post-1945 period, particularly at the higher stages (above approximately $95 \mathrm{ft}$ ). The stage duration curve for the 1945 1972 period is much lower than in the post-1973 periods. This is likely a result of the lower discharges during this period. The flow-adjusted stage duration curve for Lake Providence is shown in Figure 2-20. Removing the influence of flow variability produces a slightly different view of the stage duration trends. As shown in Figure 2-20, both pre-1944 curves are consistently higher than the post-1945 curves. For example, a stage of 107, which is approximately the flood stage at the gage, was equaled or exceeded approximately $13 \%$ of the time prior to 1944 compared to 
approximately $3 \%$ for the $1944-1972$ and the $1973-1993$ periods and approximately 6\% in the $1994-2014$ period. Also, the $1944-1972$ curve is now almost coincident with the $1973-1993$ curve. Note that above a stage of approximately $90 \mathrm{ft}$, the $1994-2014$ curve begins to deviate slightly from the other post-1944 curves, suggesting continued stage increases (aggradation) at the higher flows during this period.

Figure 2-19. Lake Providence stage duration curve using time periods in Table 2-14.

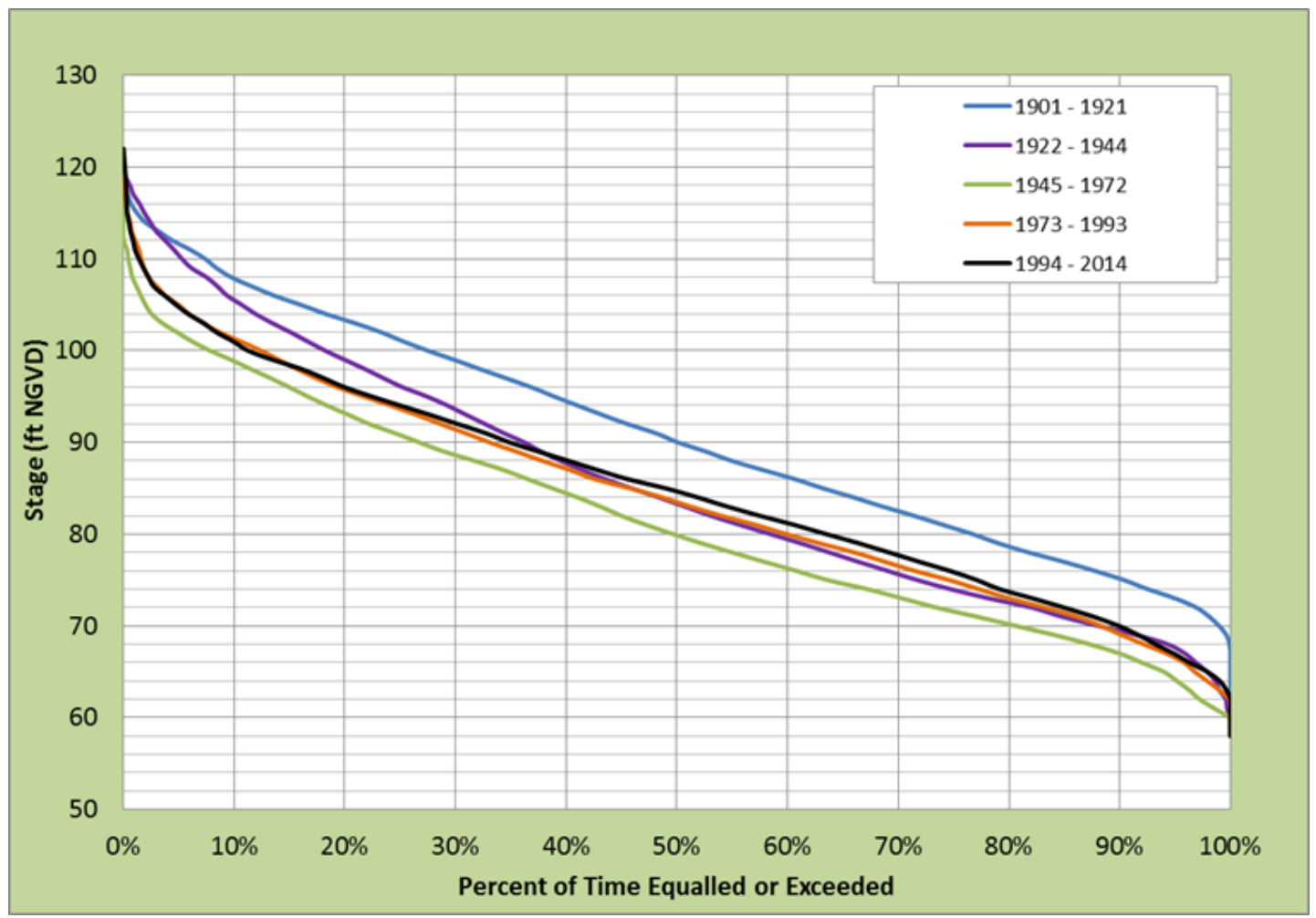


Figure 2-20. Flow-adjusted stage duration curves at Lake Providence.

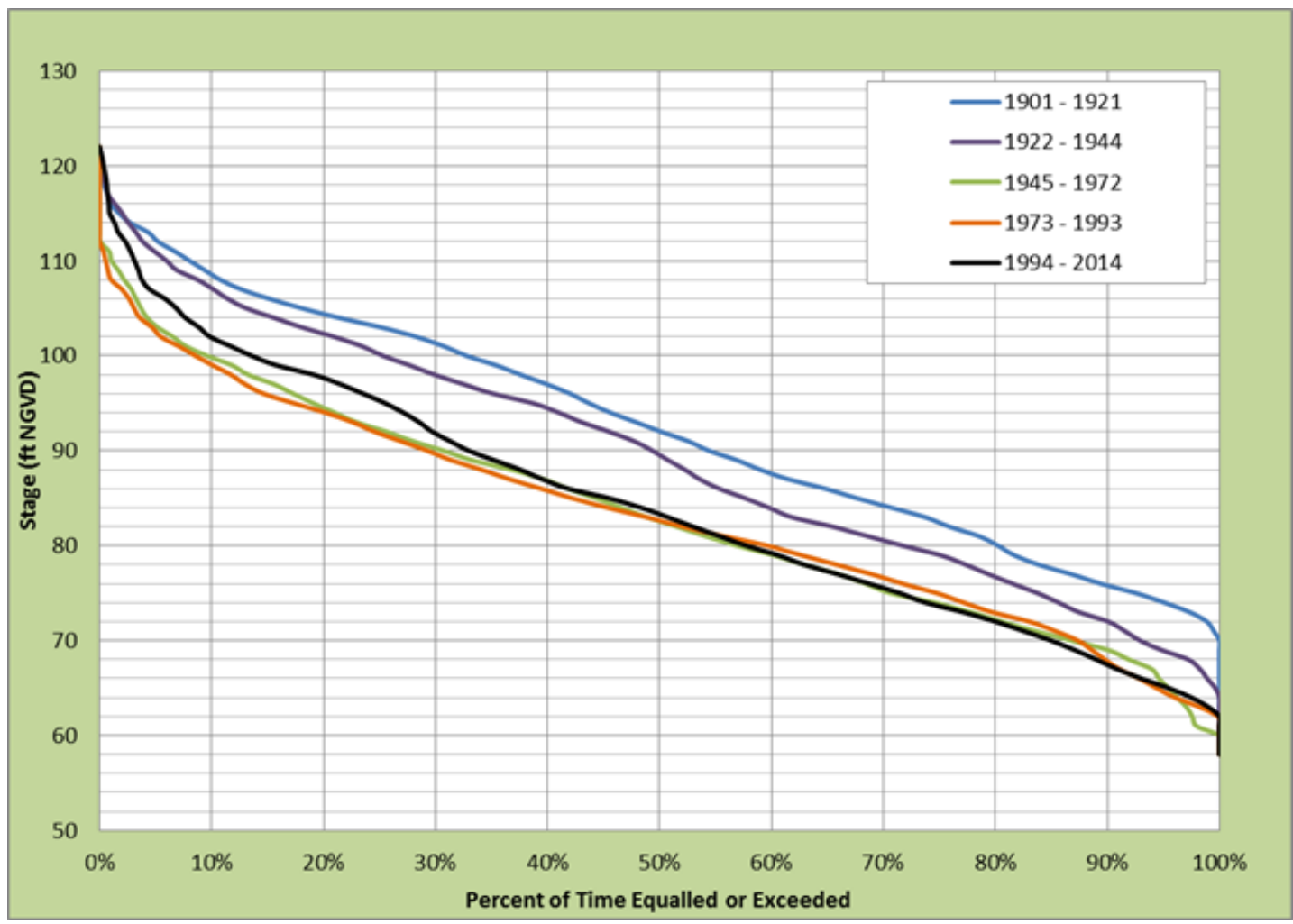

\section{Vicksburg}

The stage duration curves for Vicksburg (Figure 2-21) show that at the higher stages, the pre-1944 curves were generally higher than the post1945 curves. The 1945 - 1972 stage duration curve was generally lower than the post-1973 curves, which again probably reflects the lower discharges during this period. The flow-adjusted duration curves (Figure 2-22) show that the pre-1944 curves were consistently higher than the post-1944 curves at the higher stages (above a stage of approximately $65 \mathrm{ft}$ ). As shown in Figure 2-22, an elevation of $89 \mathrm{ft}$ (approximate flood stage elevation) in the pre-1944 period was equaled or exceeded approximately $12 \%$ of the time while in the post-1944 periods it was only equaled or exceeded between approximately $4 \%$ and $6 \%$ of the time. Below a stage of approximately $65 \mathrm{ft}$, the pre-1944 curves are still slightly higher than the post-1944 curves, but they are beginning to coalesce into approximately the same range. 
Figure 2-21. Vicksburg stage duration curve using time periods in Table 2-14.

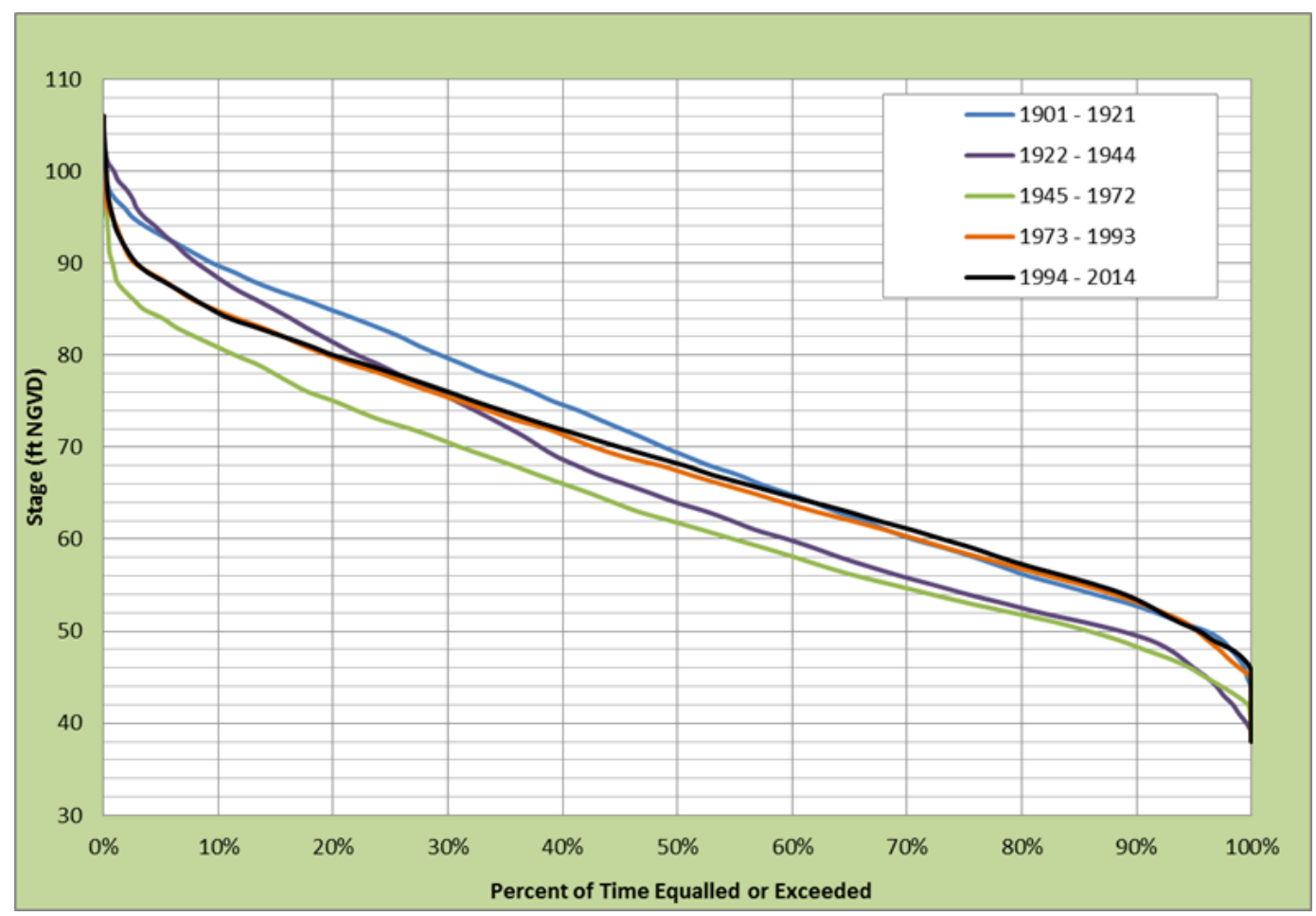

Figure 2-22. Flow-adjusted duration curves at Vicksburg.

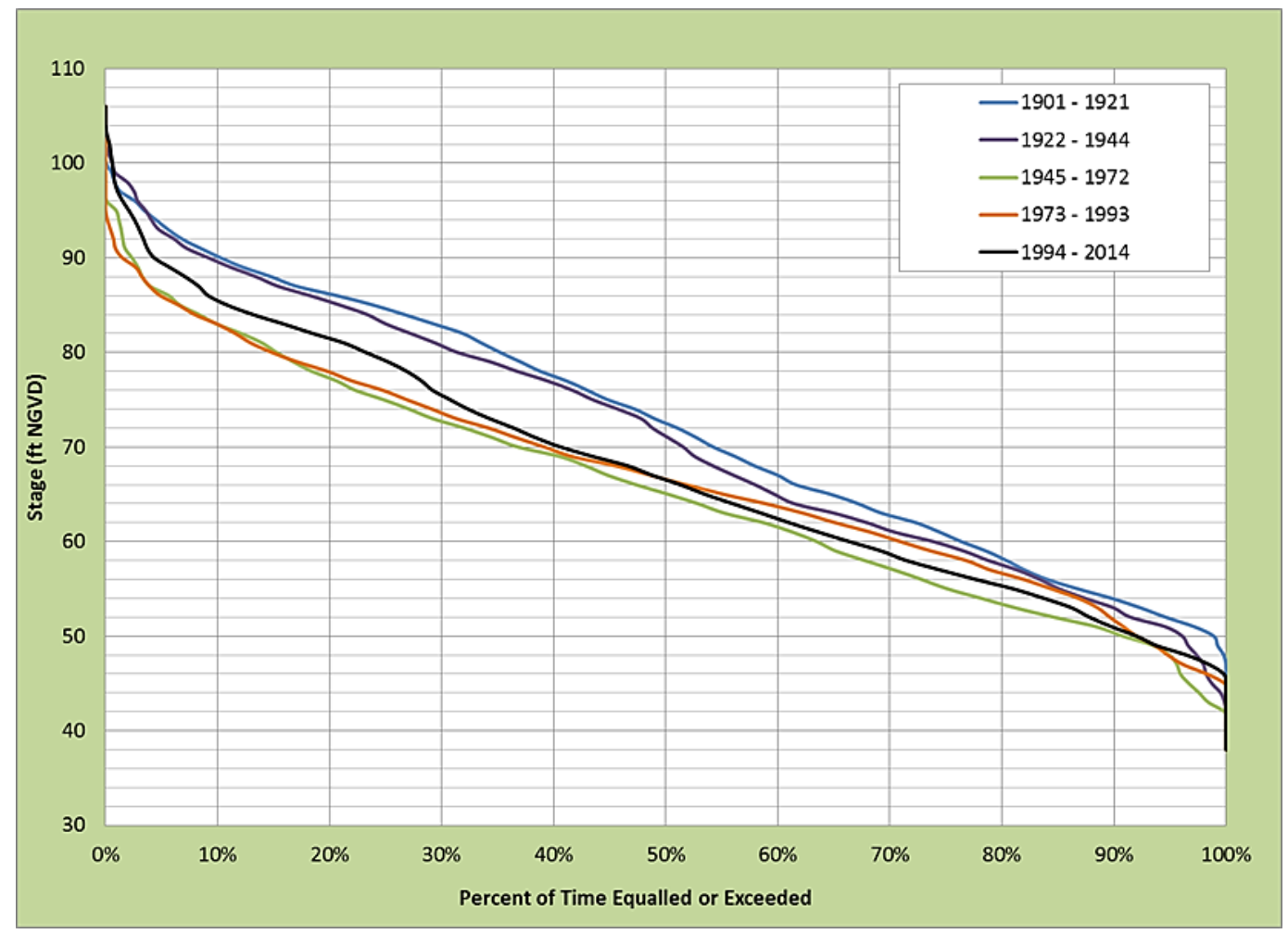




\section{St. Joseph}

The St. Joseph stage duration curves are shown in Figure 2-23. As shown in Figure 2-23, the most recent time period is the 1973 - 1993 period due to the discontinuance of the St. Joseph gage. As shown in Figure 2-23, there is considerable variability among the curves, making it difficult to identify any consistent temporal trends. However, when the flow-adjusted duration curves in Figure 2-24 are examined, a clearer picture emerges. As shown in Figure 2-24, the pre-1944 curves are somewhat higher than the post-1944 curves above a stage of approximately $55 \mathrm{ft}$. However, the stage variation range between the curves is much smaller than in the two upstream stations. In the pre-1944 period, the approximate flood stage elevation of $73 \mathrm{ft}$ was equaled or exceeded approximately $10 \%$ of time while in the post-1944 periods, this stage was only equaled or exceeded approximately $5 \%$ of the time. At the lower stages, below approximately $55 \mathrm{ft}$, there is considerable variability in the curves making it difficult to identify any significant trends.

Figure 2-23. St. Joseph Stage duration curve using time periods in Table 2-14.

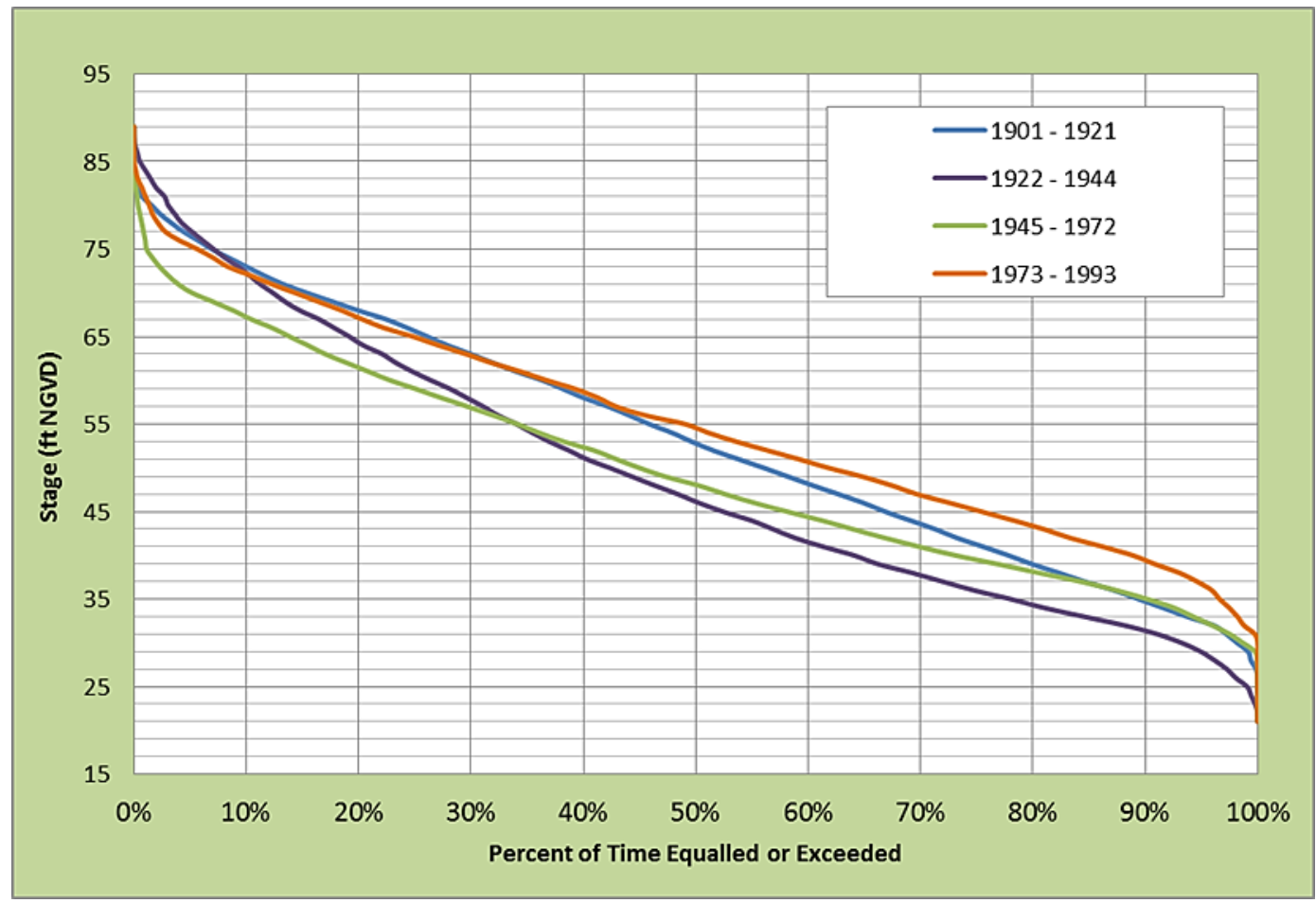


Figure 2-24. Flow-adjusted duration curve at St. Joseph.

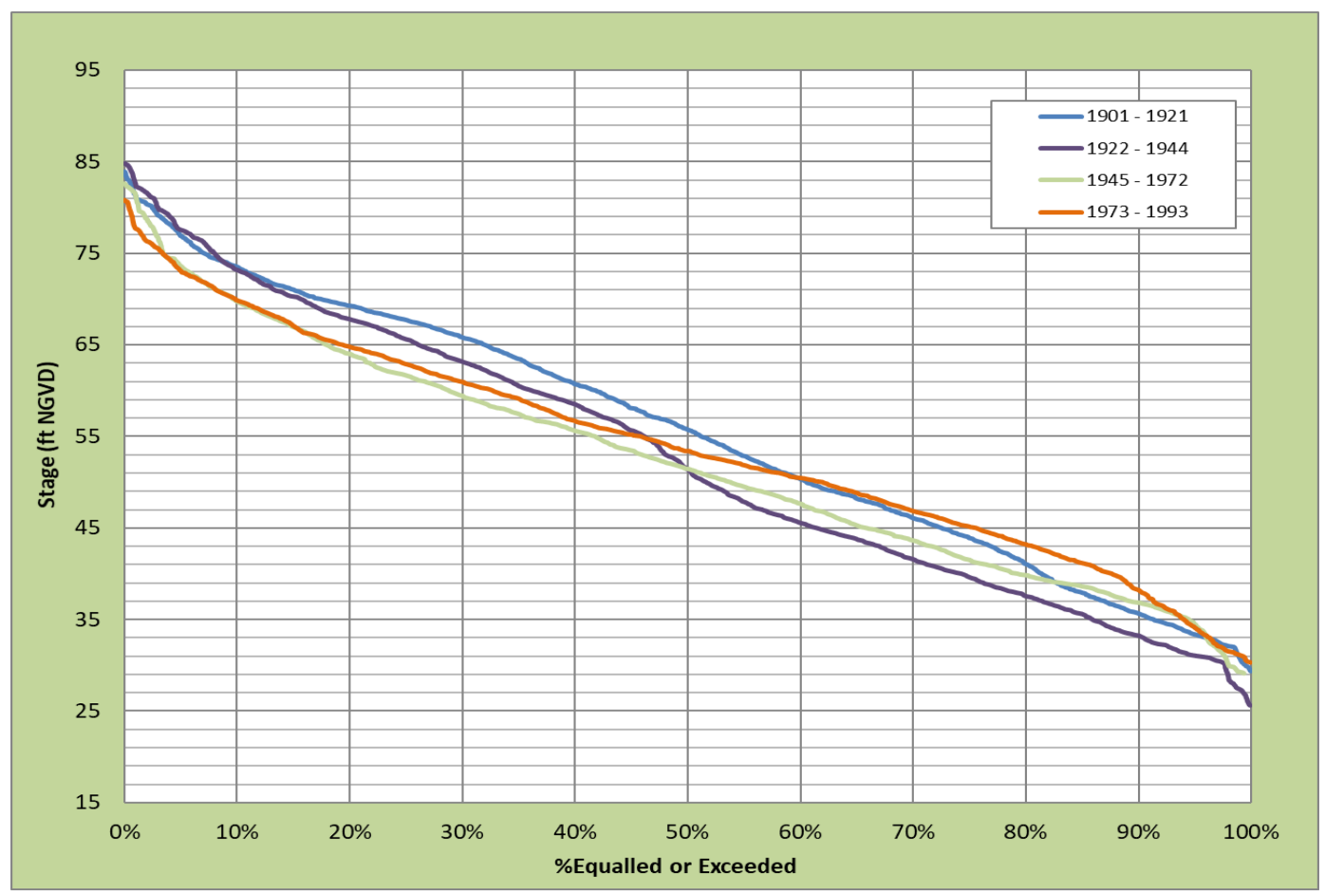

\section{Natchez}

The stage duration curves for Natchez (Figure 2-25) indicate that the post1973 stages are higher than all previous time periods throughout the entire stage range. However, examination of the flow-adjusted duration curves in Figure 2-26 provides a more insightful understanding of the trends. As shown in Figure 2-26, the curves have coalesced considerably particularly at the higher stages. Above a stage of approximately $55 \mathrm{ft}$, the curves for all time periods except $1993-2014$ are tightly packed. Prior to 1993, a flood stage elevation of approximately $65 \mathrm{ft}$ was equaled or exceeded approximately $5 \%$ of the time. However, this same stage in the $1993-$ 2014 time period was equaled or exceeded approximately $9 \%$ of the time. 
Figure 2-25. Natchez stage duration curve using time periods in Table 2-14.

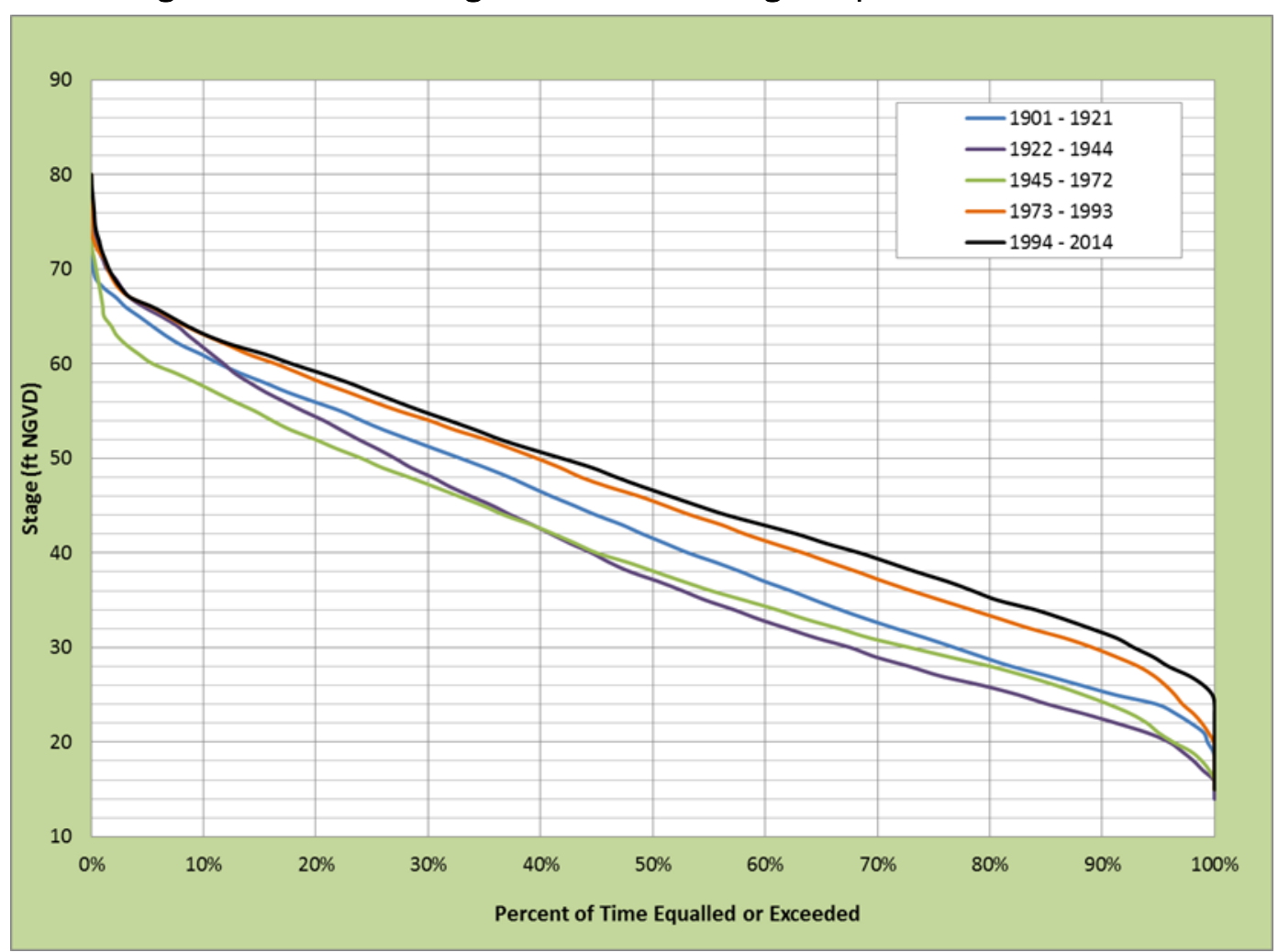

Figure 2-26. Flow-adjusted duration curves at Natchez.

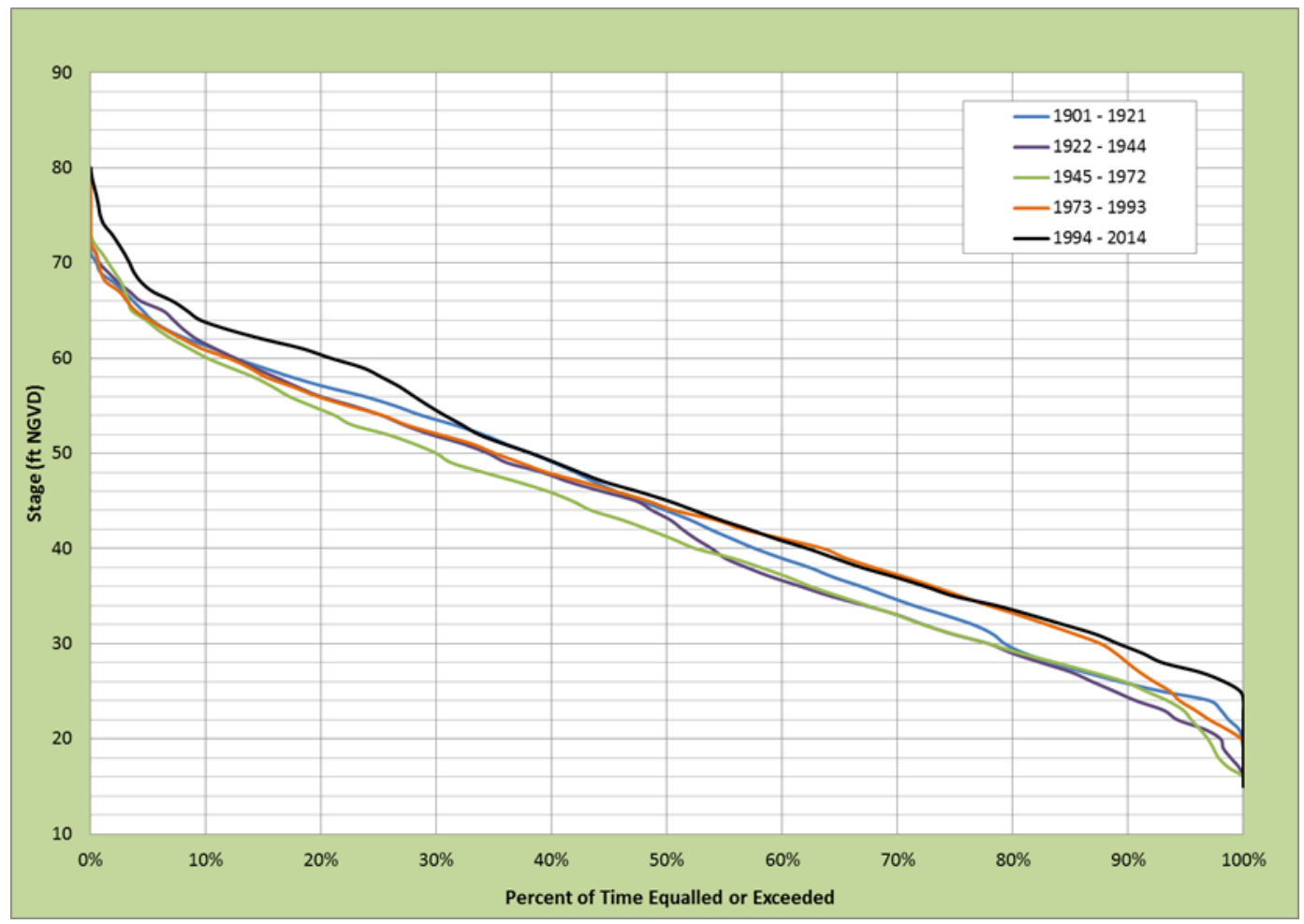




\section{Stage duration summary}

The study reach has been subjected to significant geomorphic changes since the early-1900s, with the meander cutoffs in the 1930s being the primary driver of change. The specific gage discussion (Section 2.4.3) highlighted the degradational and aggradational changes of the river. The stage duration curves provide supplementary information that is critically important to ecological and geomorphic assessments (particularly sediment transport capacity) but also assists in developing a better understanding of flooding potential.

Table 2-16 shows the stage duration changes for low water stages (approximately +5 on the gage), mid-bank stages (approximately +20 on the gage), and flood stages for the Pre-cutoff and 1993-2014 time periods. Also shown in Table 2-16 are the percent changes in duration between the time periods for each stage. Negative values indicate that the particular stage is equaled or exceeded less frequently in the present-day river compared to the pre-cutoff period. Positive values (shown in red) indicate that the stages are equaled or exceeded more frequently. As shown in Table 2-16, there is a general trend in duration changes from upstream to downstream.

Lake Providence, located at the upstream end of the study reach, shows the largest stage duration changes, with reductions of approximately $24 \%$ at the low- to mid-range stages and $9 \%$ at the flood stages. Moving downstream, the percent changes become less and less, eventually showing increases in stage duration at Natchez. Of particular interest in Table 2-16 are the stage duration changes at the flood stage elevation. The flood stage elevation is the elevation where flooding begins to impact floodplain areas. This is also often associated with the bankfull stage, which is important for geomorphic studies. As shown in Table 2-16, the percentage of time that the flood stage is equaled or exceeded at Lake Providence and Vicksburg is approximately $6 \%$ to $9 \%$ less frequent than it was in the Pre-cutoff Period. The percent change at St. Joseph is also approximately $6 \%$, but it must be remembered that this value reflects the changes only through 1993. It is likely that if data existed through 2014, this value would be much smaller and possibly even positive. At Natchez, the flood stage elevation is presently equaled or exceeded approximately $9 \%$ of the time as compared to approximately only $5 \%$ of the time in the Pre-cutoff Period. Thus, these areas are being inundated for longer durations than previously. 
Table 2-16. Stage duration changes for a range of flow conditions.

\begin{tabular}{|l|c|c|c|c|c|c|c|c|c|}
\hline \multirow{2}{*}{\begin{tabular}{|} 
Gage \\
Location*
\end{tabular}} & \multicolumn{6}{|c|}{ Percentage of Time Stage Is Equaled or Exceeded } \\
\cline { 2 - 10 } & $\begin{array}{c}\text { Pre- } \\
\text { cutoff }\end{array}$ & $\begin{array}{c}1993- \\
2014\end{array}$ & $\begin{array}{c}\% \\
\text { Change }\end{array}$ & $\begin{array}{c}\text { Pre- } \\
\text { cutoff }\end{array}$ & $\begin{array}{c}1993- \\
\mathbf{2 0 1 4}\end{array}$ & $\begin{array}{c}\% \\
\text { Change }\end{array}$ & $\begin{array}{c}\text { Pre- } \\
\text { cutoff }\end{array}$ & $\begin{array}{c}\text { 1993- } \\
\mathbf{2 0 1 4}\end{array}$ & $\begin{array}{c}\% \\
\text { Change }\end{array}$ \\
\hline $\begin{array}{l}\text { Lake } \\
\text { Providence } \\
\text { (69.71 ft) }\end{array}$ & $95 \%$ & $71 \%$ & $-24 \%$ & $57 \%$ & $33 \%$ & $-24 \%$ & $15 \%$ & $6 \%$ & $-9 \%$ \\
\hline $\begin{array}{l}\text { Vicksburg } \\
\text { (46.23 ft) }\end{array}$ & $98 \%$ & $90 \%$ & $-8 \%$ & $64 \%$ & $51 \%$ & $-13 \%$ & $12 \%$ & $6 \%$ & $-6 \%$ \\
\hline $\begin{array}{l}\text { St. Joseph** } \\
\text { (33.12 ft) }\end{array}$ & $85 \%$ & $90 \%$ & $5 \%$ & $55 \%$ & $51 \%$ & $-4 \%$ & $11 \%$ & $5 \%$ & $-6 \%$ \\
\hline $\begin{array}{l}\text { Natchez } \\
\text { (17.23 ft) }\end{array}$ & $98 \%$ & $100 \%$ & $2 \%$ & $65 \%$ & $70 \%$ & $5 \%$ & $5 \%$ & $9 \%$ & $4 \%$ \\
\hline
\end{tabular}

* Gage zero is shown parentheses.

** The present-day time period for St. Joseph is 1973-1993.

\subsubsection{Bed material characteristics}

This section describes the bed material characteristic in the study reach. The data in this section come from three sources: (1) bed material samples collected at the permanent gaging stations at Vicksburg and Natchez; (2) the bed material trends based on the 1932, 1989, and 2013 sampling (Gaines and Priestas 2016); and (3) the Robbins (1977) bed material data collected as part of the Potamology Program in the 1960s and 1970s.

\section{Bed material trends at permanent gaging stations (Vicksburg to Natchez)}

Bed material samples are available for the sediment stations at Vicksburg and Natchez for the period from 1985 to 2004 (Thorne et al. 2008). These samples are collected in association with the measured suspended sediment data. Figure 2-27 shows the bed material trends at the Vicksburg station. Although there is considerable scatter in the data, there are no sustained long-term trends that are evident. It is interesting that the gravel component of the $\mathrm{D}_{84}$ plot disappears completely after 1992. The reason for this loss of gravel is not clear. It may be a real physical phenomenon or some artifact of the sampling procedures. Further investigation of this is warranted.

Box and whisker plots were developed to display the variability in the bed material data. The bottom of the box (referred to as the lower hinge) 
represents the 25th percentile of the data, and the top (upper hinge) represents the 75th percentile, with the band near the middle of the box representing the median particle size $\left(\mathrm{D}_{50}\right)$. Note that this is not the same as the mean particle size unless the scatter is normally distributed, which is not the usual case for these samples. Fifty percent of the data is within the box (i.e., between 25th and 75th percentiles). The whiskers are related to the height of the box, which is referred to as the interquartile range (IQR). For this investigation, the extent of the whiskers was defined as the lowest data point within $1.5 \times$ IQR of the lower quartile and the highest data point within $1.5 \times$ IQR of the upper quartile. Data outside the whisker limits that are depicted as crosses are referred to as outliers.

The box and whisker plots for the Vicksburg data are shown Figure 2-28. As shown in Figure 2-28, the median value (50th percentile) for D50 is approximately 0.41 millimeter $(\mathrm{mm})$ while the $25^{\text {th }}$ and $75^{\text {th }}$ percentile values range from $0.37 \mathrm{~mm}$ to $0.47 \mathrm{~mm}$, respectively. Also highlighted in Figure 2-28 are the multiple $\mathrm{D}_{84}$ outliers that reflect the occurrence of gravel in the samples.

At Natchez (Figure 2-29), there were no sustained bed material trends that could be observed. However, there was a period between 1998 and 2001 when the bed material apparently became much finer. The $\mathrm{D}_{84}$ plot in Figure 2-29 shows a loss of gravel after 1988. This loss of gravel, as well as the fining of the bed between 1998 and 2001, warrants further investigation to determine whether these are real phenomena or some artifact of the sampling procedures. As shown in the box and whisker plot in Figure 2-30, the D50 for Natchez is approximately $0.36 \mathrm{~mm}$, with an IQR between $0.33 \mathrm{~mm}$ and $0.39 \mathrm{~mm}$.

In summary, there were no sustained temporal trends in the bed material data at either Vicksburg or Natchez. Spatially, there does appear to be a general fining of the bed in the downstream direction. For example, the $\mathrm{D}_{50}$ at Vicksburg is approximately $0.41 \mathrm{~mm}$ as compared to Natchez with a $\mathrm{D}_{50}$ of $0.36 \mathrm{~mm}$. There are also two interesting phenomenon that need to be further investigated. The first is the apparent absence of grain size data larger than gravel in the late 1980 os to early 1990 s, and the second is the apparent fining of the bed at Natchez between 1998 and 2001. 
Figure 2-27. Bed Material trends at the Vicksburg gaging station.

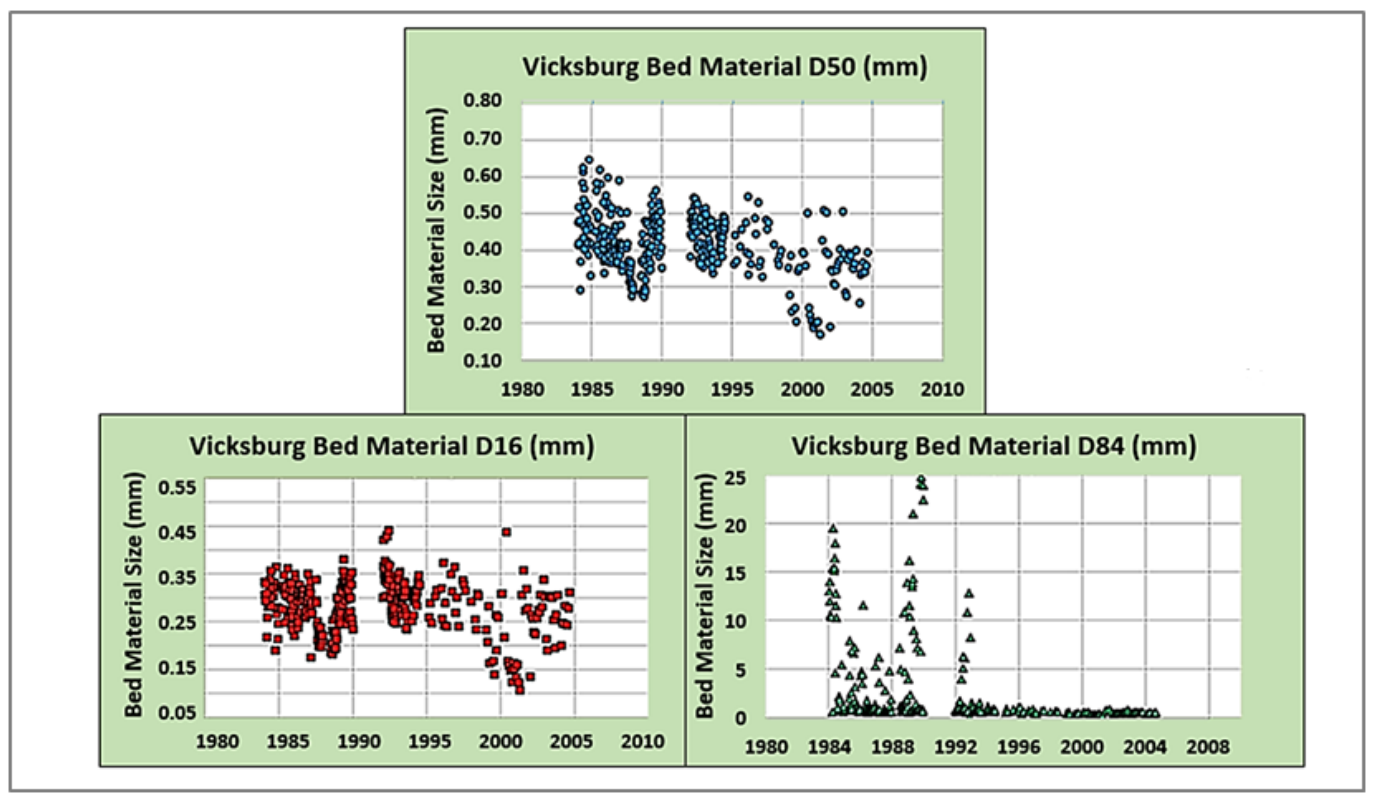

Figure 2-28. Box and whisker plot for the Vicksburg bed material data.

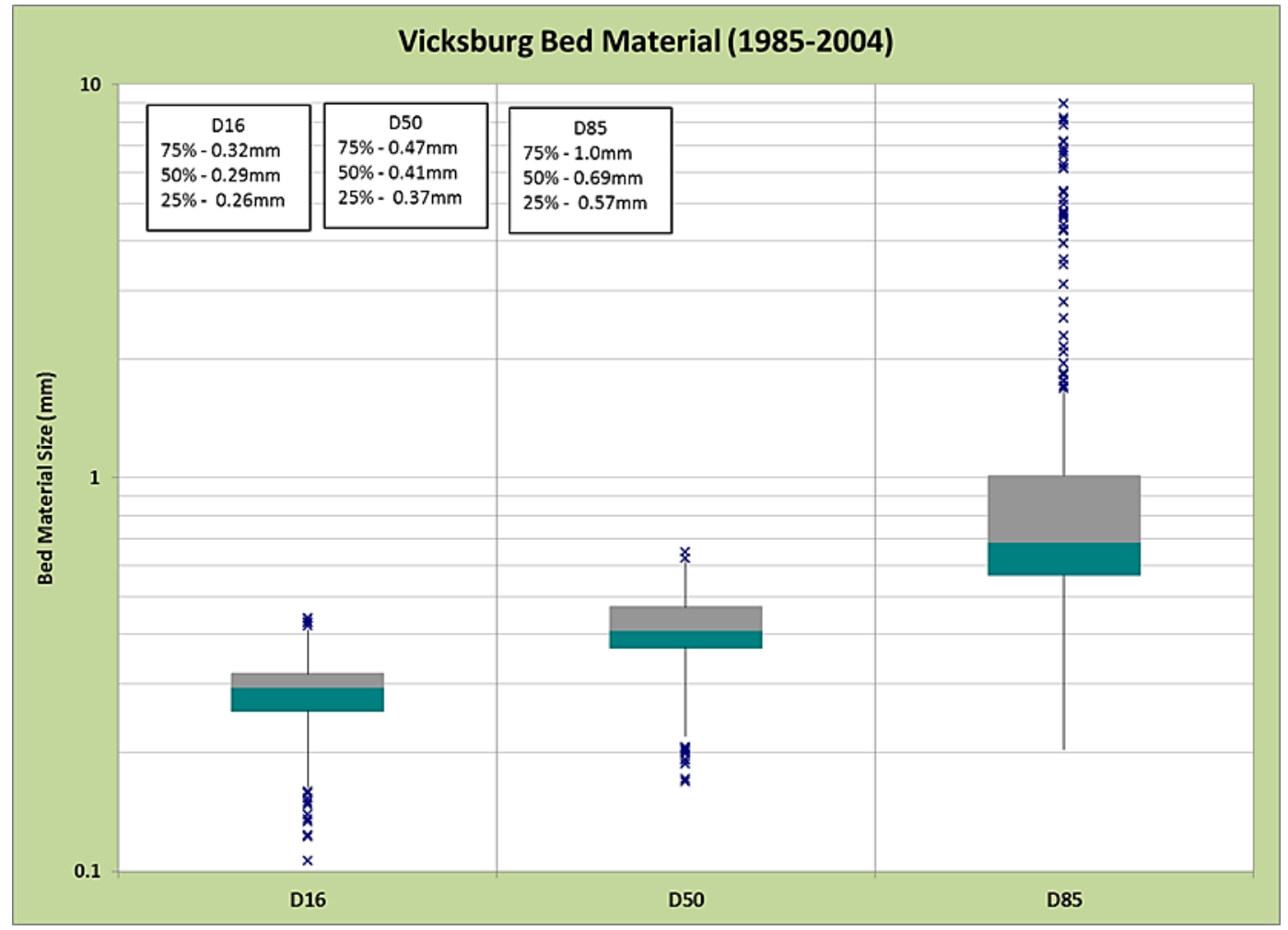


Figure 2-29. Bed material trends at the Natchez gaging station.

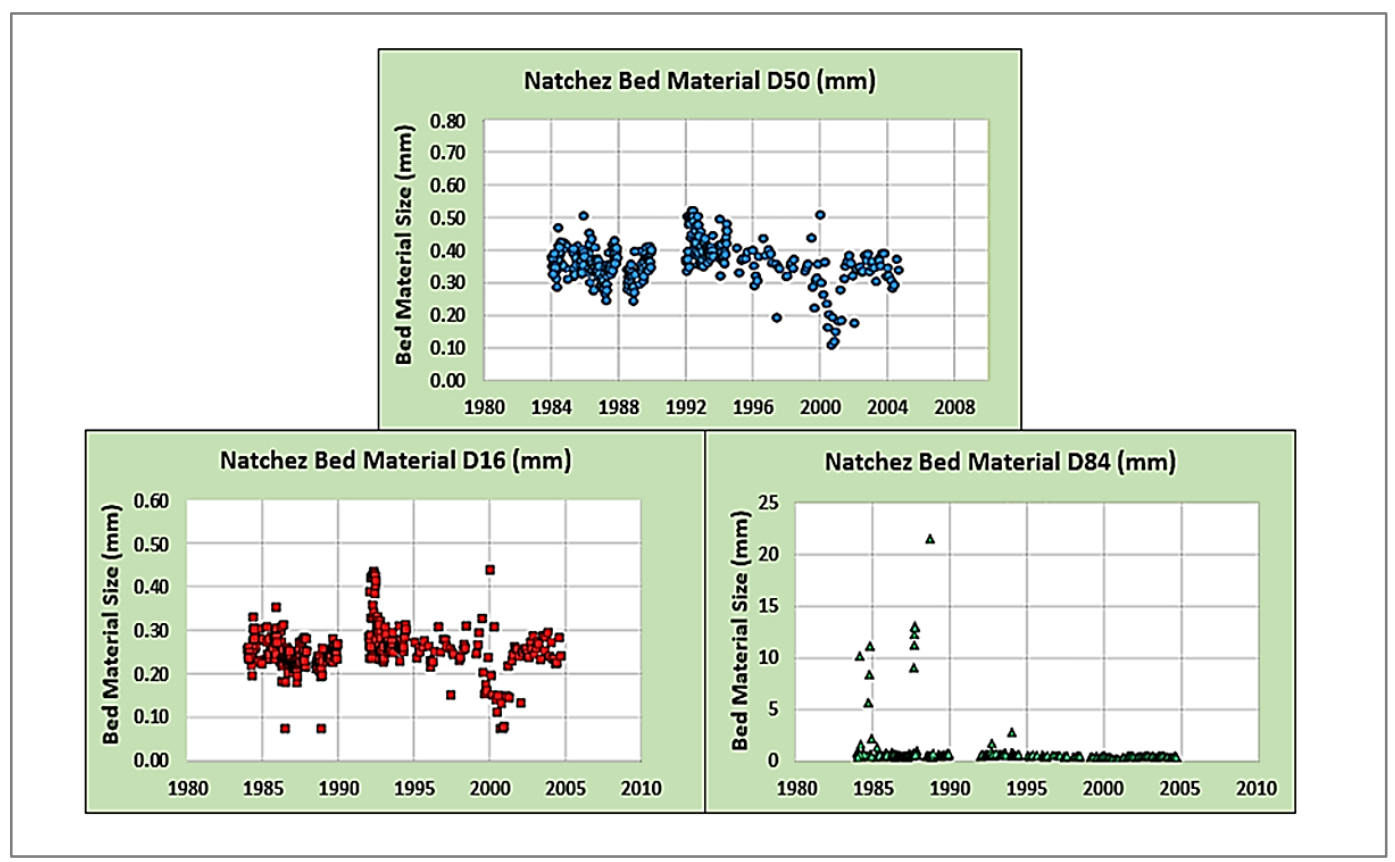

Figure 2-30. Box and whisker plot for the Natchez bed material data.

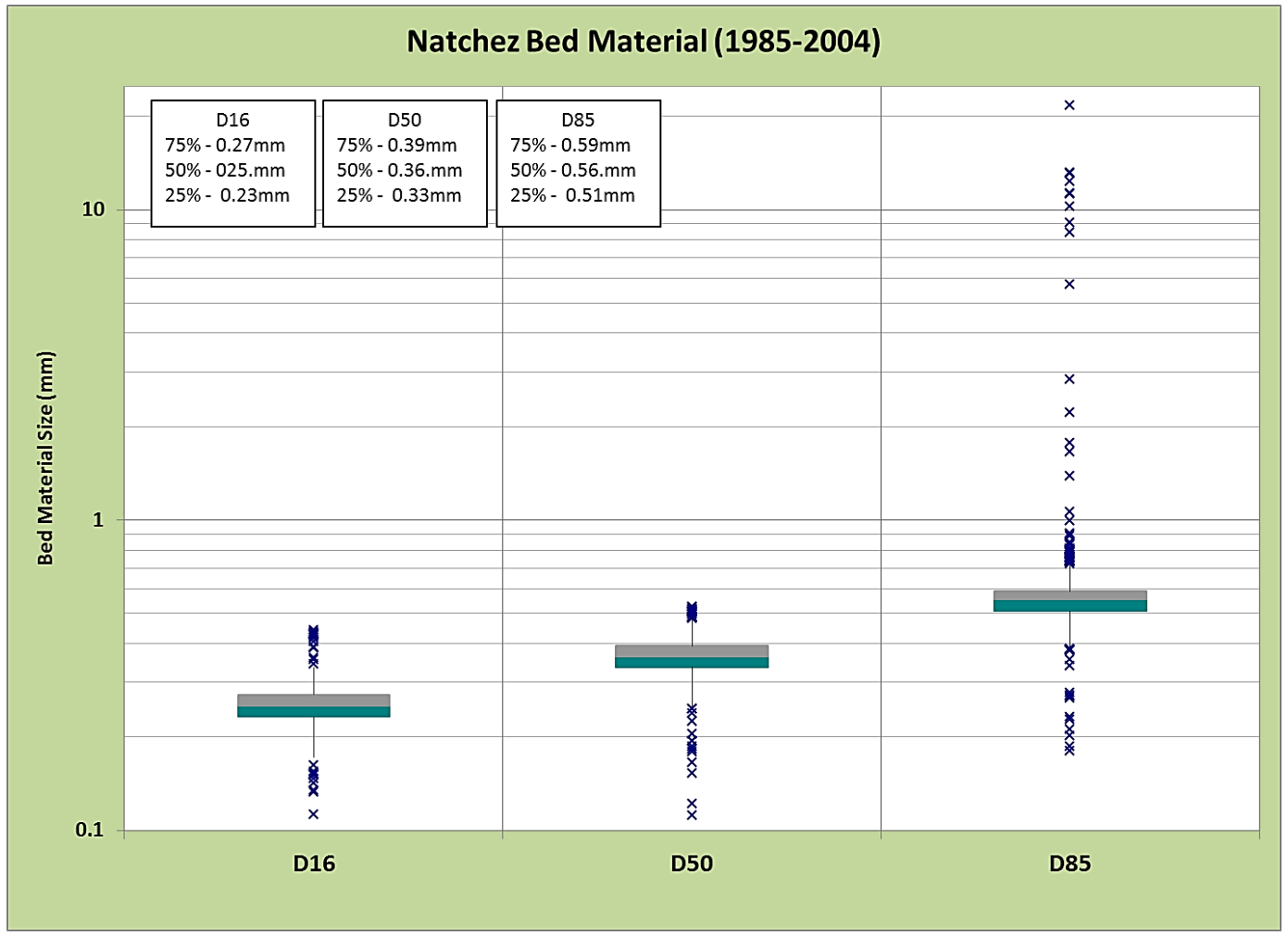


Gaines and Priestas (2016) particle size distributions of bed sediments

Gaines and Priestas (2016) compared bed material gradations collected in 2013 to bed material gradations for 1932 (WES 1935) and 1989 (Nordin and Queen 1992). The findings documented in the report are based on 754 bed material samples collected in November 2013 at 496 locations spaced at intervals of 2 to 3 miles along the Mississippi River between Grafton, IL, and Head of Passes, LA. Data collection procedures in 2013 were matched as closely as possible to the procedures used for the collection of bed material samples in 1932 and 1989. (More detailed information about the sampling protocols and particle size analysis are included in the Gaines and Priestas (2016) report.)

In this section, the bed material data contained in the Gaines and Priestas (2016) report that pertain to the study reach are presented. Figure 2-31 shows the downstream trends in median $\left(\mathrm{D}_{50}\right)$ grain sizes measured in November 2013 in the LMR between Cairo, IL, and Head of Passes, LA. River miles between Lake Providence and Old River are within the red box. According to the regression line in Figure 2-31, the $\mathrm{D}_{50}$ at Vicksburg and Natchez is approximately 0.36 and $0.3 \mathrm{~mm}$, respectively. These values are slightly less than the $\mathrm{D}_{50}$ values reported in the previous section for the permanent gaging stations at Vicksburg and Natchez. A possible explanation for these differences may be that the Gaines and Priestas data were a single collection near the thalweg while at the permanent gaging stations, the data are averaged across the entire cross section.

Figure 2-32 shows downstream trends in the bed material grain size distributions in the Lower Mississippi River in 1932 (a), 1989 (b), and 2013 (c). River miles between Lake Providence and Old River are shown within the red box. The study reach had a higher amount of very coarse sand and gravel (2 mm or larger) in 1932 when the bed material grain size distributions are compared with the 1989 and 2013 gradations. It is also noticed that very fine sand $(0.0625 \mathrm{~mm}-0.125 \mathrm{~mm})$, coarse silt $(0.004 \mathrm{~mm}$ $-0.062 \mathrm{~mm}$ ), and clay $(<0.004 \mathrm{~mm}$ ) have decreased over time. In fact, in 1989 and 2013, there was essentially no bed material finer than very fine sands in the bed, with the exception of a very small amount near the downstream end of the reach in 1989. However, the amount of medium sand within the study reach has increased relative to the 1932 sampling.

In summary, the Gaines and Priestas (2016) data confirm that there is a downstream fining in the bed material size in the study reach, with the 
average D50 at Vicksburg and Natchez being approximately $0.36 \mathrm{~mm}$ and $0.3 \mathrm{~mm}$, respectively. Comparison of the data also revealed a significant reduction in the amount of gravel in the bed relative to the 1932 sampling. Their data also show that there were no appreciable amounts of bed material in the very fine sand, silts, and clay ranges in the 1989 and 2013 data.

Figure 2-31. Downstream trends in $D_{50}$ in November 2013 - Study reach outlined in red (Gaines and Priestas 2016).

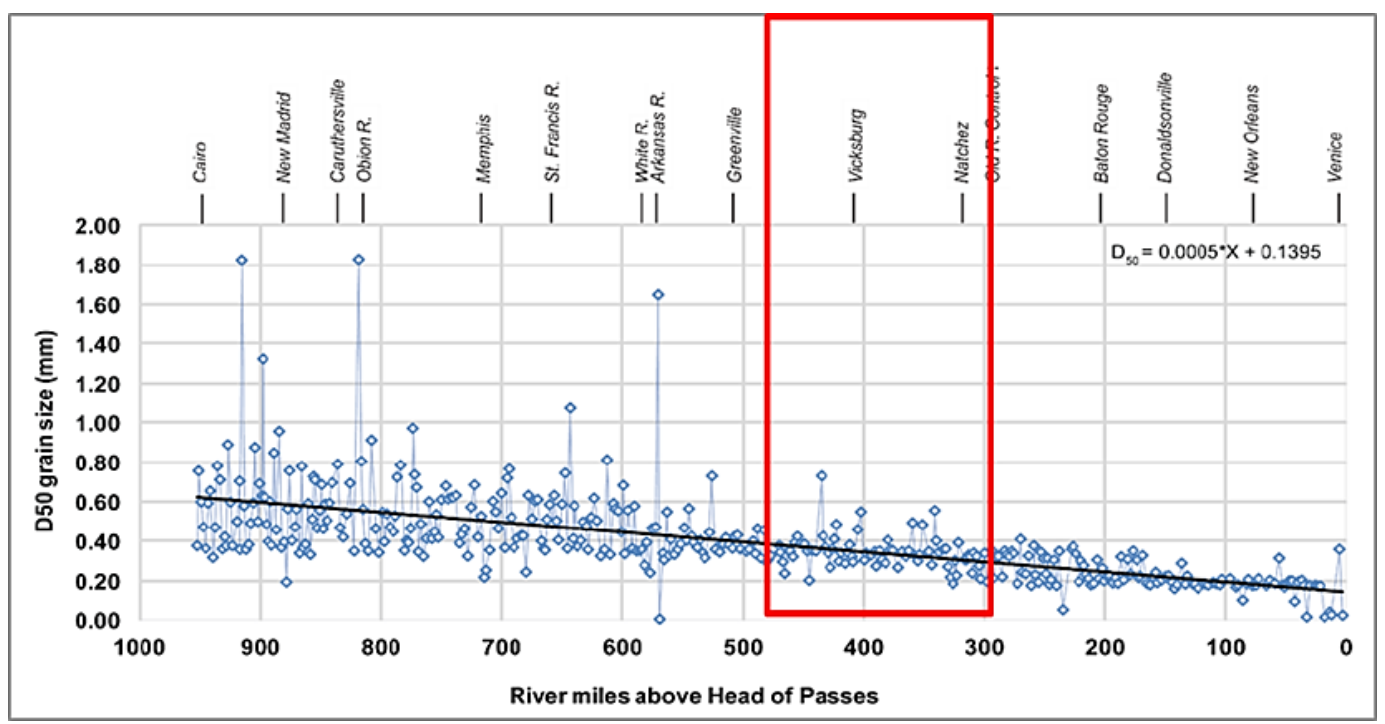


Figure 2-32. Downstream trends in bed material grain size distributions in the LMR in (a) 1932, (b) 1989, and (c) 2013 - Study reach outlined in red (Gaines and Priestas 2016).

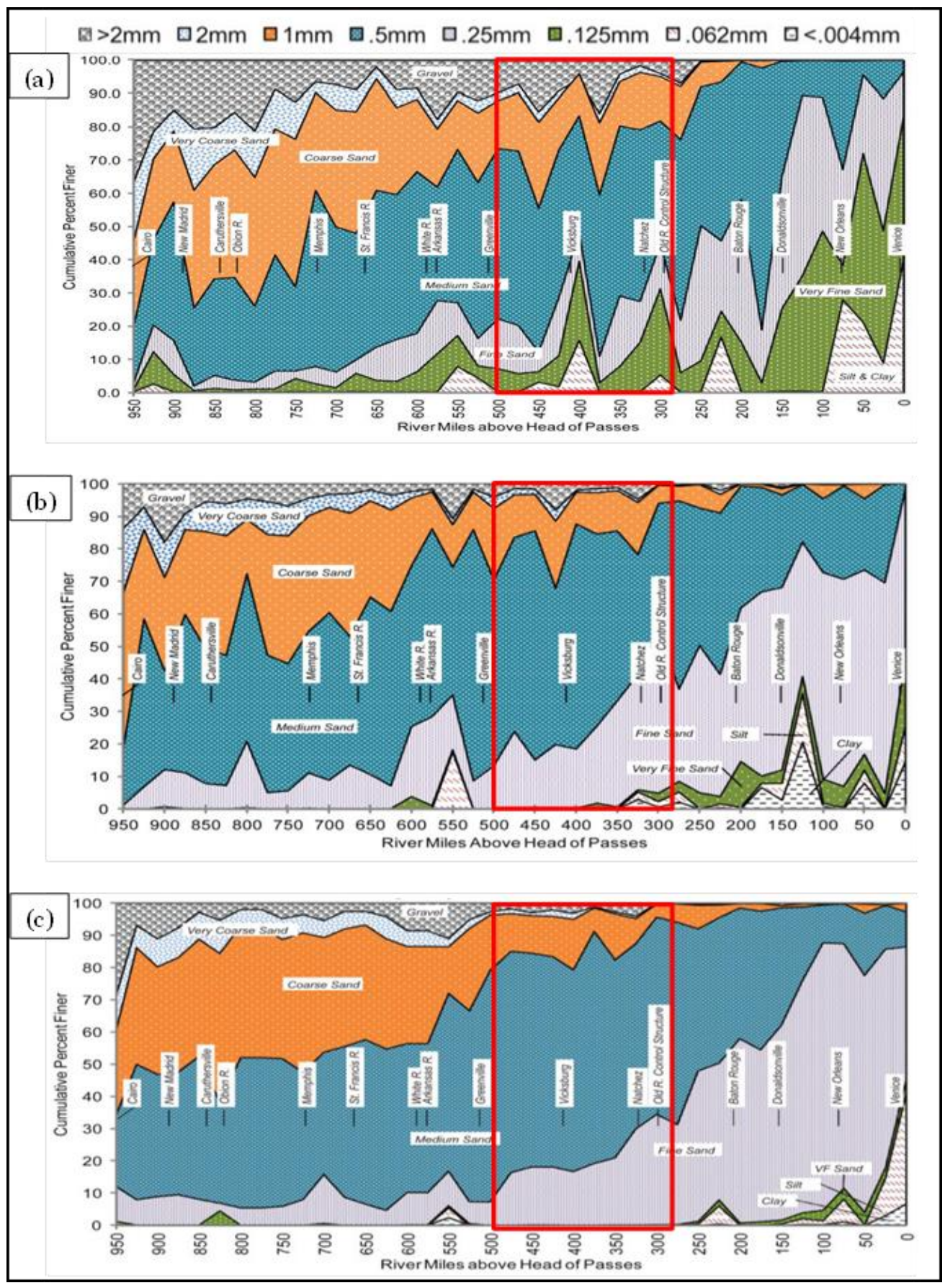

Robbins (1977) bed material trends

Robbins (1977) published a study of the suspended sediment and bed material trends within the USACE Vicksburg District reach to identify possible trends in the datasets that might have relevance for navigation and flood control. Using the Robbins (1977) data, Thorne et al. (2017) 
conducted detailed analysis of the spatial and temporal bed material trends. The data presented herein are summarized from these two reports.

As part of the Vicksburg District's Potamology Program, the Vicksburg District was divided into 25 potamology reaches. Between 1966 and 1974, the district conducted extensive data collection and analyses in these reaches. Typically data that were collected (sometimes several times per year) included hydrographic surveys, suspended sediment samples, bed material samples, slope measurements, and discharge measurements. Fourteen of the 25 reaches were included within the study reach between Lake Providence and Old River (Table 2-17). In each reach, bed sediment samples were collected at specific sediment study ranges. At each range, between 4 and 12 bed material samples were collected, depending on the width of the cross section.

The extensive sampling conducted in the potamology reaches over the 9-year period provides valuable insight into the variability of the bed material composition. Figure 2-33 shows the variability between years in the bed material gradations for four selected reaches. Examination of these plots clearly shows that there is considerable temporal variability in the bed material gradation. For example, for the Cottonwood Bar reach, the D50 is seen to vary from approximately $0.2 \mathrm{~mm}$ to $0.45 \mathrm{~mm}$.

Box and whisker plots were developed to show the trends and variability in the D50, D16, and D84 values in the study reach (Figure 2-34). As shown in Figure 2-34, there are reach-scale fluctuations in the data, but there is no evidence of significant downstream, decreasing trends. However, there does appear to be a coarsening of the bed material in the Belle Island to Vicksburg reach (RM 456.6 - 443.4). The average D5o for the study reach is approximately $0.31 \mathrm{~mm}$.

In summary, the potamology data indicate that there are considerable variability and reach-scale fluctuations in the bed material data between years. However, no downstream, decreasing trends in the data were observed. The Robbins (1977) data indicate that the dominant bed size is sand with an average D50 of approximately $0.31 \mathrm{~mm}$. The D16 fluctuates within the fine sand range while the D84 is typically in the lower end of the coarse sand size classes. However, there are some reaches that do contain significant quantities of gravel size material. 
Table 2-17. Fourteen potamology reaches used in the bed material analysis.

\begin{tabular}{|l|c|c|c|c|}
\hline Potamology Reach & $\begin{array}{c}\text { Extent } \\
\text { (RM AHP) }\end{array}$ & $\begin{array}{c}\text { RM } \\
\text { (Mid-Point) }\end{array}$ & $\begin{array}{c}\text { Reach } \\
\text { Length } \\
\text { (miles) }\end{array}$ & Period of Record \\
\hline Ajax Bar & $485.7-479.7$ & 482.7 & 5.8 & $1966-1974$ \\
\hline Ajax-Cottonwood & $472-479.8$ & 475.9 & 7.8 & $1968-1974$ \\
\hline Cottonwood Bar & $467.8-472$ & 469.9 & 4.2 & $1966-1974$ \\
\hline Cottonwood Belle Island & $461.4-467.8$ & 464.6 & 6.4 & $1967-1974$ \\
\hline Belle Is. - Milliken Bend & $451.8-461.4$ & 456.6 & 9.6 & $1966-1974$ \\
\hline Milliken Bend - Vicksburg & $435-451.8$ & 443.4 & 16.8 & $1968-1974$ \\
\hline Racetrack Towhead & $422.8-435$ & 428.9 & 12.2 & $1966,1968-1974$ \\
\hline Point Pleasant & $407-422.8$ & 415.1 & 15.4 & $1966,1970-1974$ \\
\hline Grand Gulf & $407.3-395.1$ & 401.3 & 12.2 & $1970-1974$ \\
\hline Rodney & $395.1-381.3$ & 388.3 & 13.8 & $1966,1968-1974$ \\
\hline Waterproof & $381.3-368.1$ & 374.8 & 13.2 & $1966,1970-1974$ \\
\hline Natchez & $368.1-355.1$ & 361.7 & 13 & $1970-1974$ \\
\hline St. Catherine & $355.1-338.5$ & 346.9 & 16.6 & $1971-1974$ \\
\hline Bougere & $338.5-320.4$ & 329.5 & 18.2 & $1972-1974$ \\
\hline
\end{tabular}

Figure 2-33. Selected bed material gradation curve in the research study.

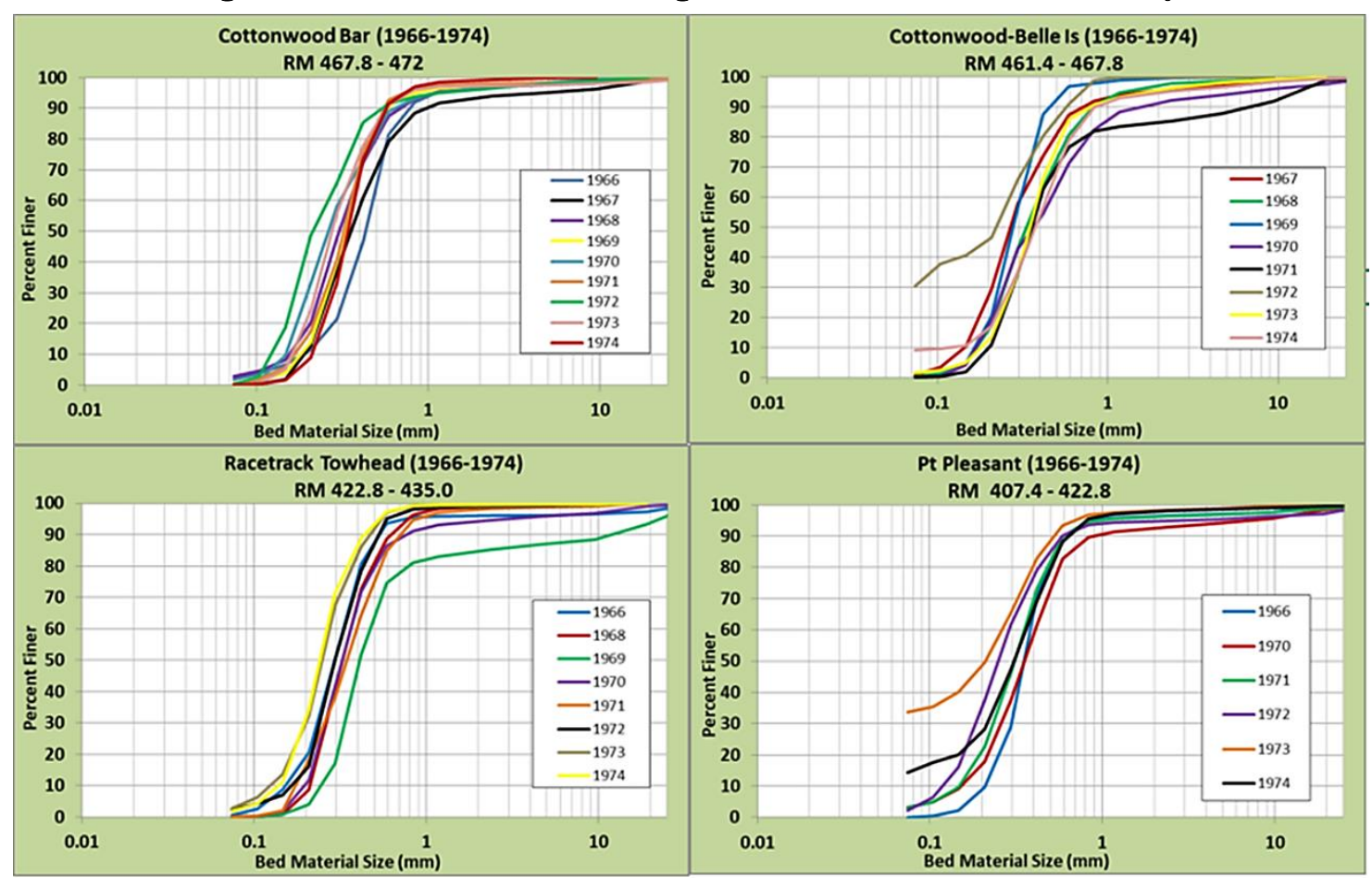


Figure 2-34. Box and whisker plots of $D_{50}, D_{16}$, and $D_{84}$ for the 14 potamology reaches.

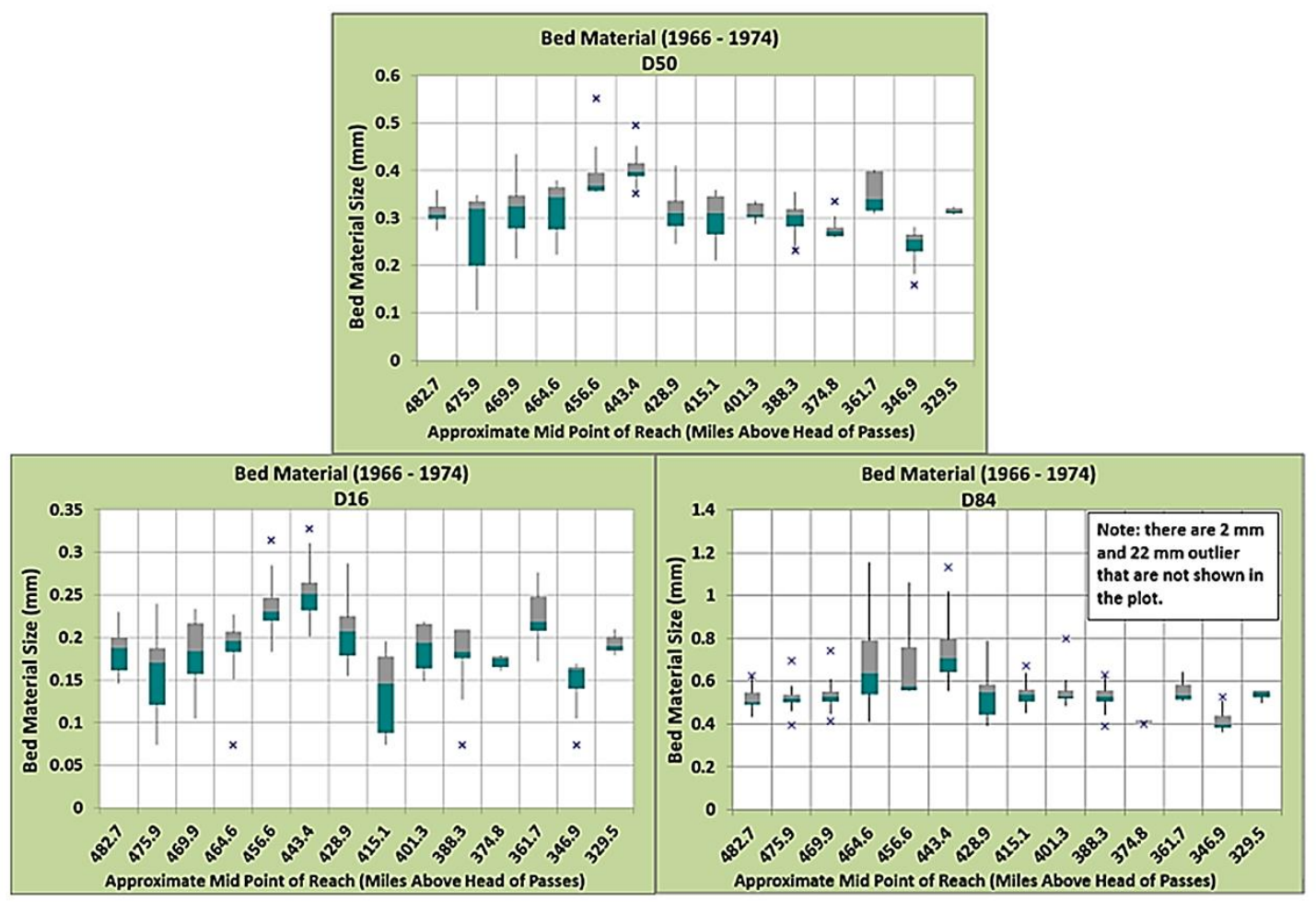

Gravel observations

In addition to his analysis of bed material samples, Robbins (1977) also commented at length on the potential causes of a significant increase in the extent of exposed gravel on middle bars and islands between the upstream limit of the Vicksburg District (at RM 606AHP) and Natchez Island (at RM $357 \mathrm{AHP}$ ), approximately $78 \mathrm{RM}$ downstream from Vicksburg. These observations were based on field investigation between 1973 and 1975. Robbins (1977) concluded that the floods of 1973, 1974, and 1975 were responsible for transporting and depositing gravel material on top of islands and middle bars. These deposits were at relatively high elevations only attained during flood events. Robbins listed a series of important observations that add important supplementary information to the results from the bed material samples. For this reason, his observations are summarized herein.

1. In the Cottonwood Bar potamology reach, gravel formed an extensive, continuous sheet at the head of a middle bar in the left channel ( $\mathrm{RM} 470$ ) comprising particles with long axes typically to 80 to 120 $\mathrm{mm}$ ( 3 to 5 inches [in.]) in size. 
2. At Togo Island Dike No. 2 (RM 416), river-transported gravel had filled the gaps between the quarry-run stone forming the dike $350 \mathrm{ft}$ out into the river. The river gravel ranged in size up to approximately $60 \mathrm{~mm}$ (expressed as 2 in. in the Robbins Report) when measured along the major axis. As the crest of the dike is 10 to $15 \mathrm{ft}$ above the river bed, the presence of gravel in the top of the dike indicates that gravel must have been carried in suspension, possibly due to very intense turbulence around the dike during high water. While this suggests that the LMR is capable of transporting coarse sediment in suspension during flood flows, Robbins noted that coarse sediment is excluded from suspended sediment samples because the nozzle of the $\mathrm{P}-61$ suspended sediment load sampler is only $0.48 \mathrm{~mm}(3 / 16 \mathrm{in}$.) in diameter.

3. Gravel cover was often extensive at the head of Middle Ground Island (RM 409). However, excavation of a trench through the bar head showed the gravel to be an armor layer with a thickness approximately equal to the diameter of the larger particles, which was underlain by sand that had gravel interspersed within it,

4. Gravel cover was observed at the heads of bars and islands as far downstream as RM 388.4, which is between Vicksburg and Natchez.

5. While gravel deposits were found through a substantial proportion of the Vicksburg reach, the proportion of the bed of the LMR that was covered by gravel is small compared to that covered by sand.

Nevertheless, the effect of a gravel armor layer at the head of a bar or islands tends to anchor the features in place, at least at low and intermediate flows and perhaps at all but the highest flows. Hence, the morphological influence and significance of the gravel armor may be considerable despite the relatively small area that it covers.

6. The extent and size of coarse bed sediment found at multiple locations within the Vicksburg District indicates that during high flows, the river transports particles far coarser than those collected during routine sampling. This indicates that while suspended load sampling records provide reliable estimates of the capacity of the Lower Mississippi River to transport sediment, they do not provide a reliable guide to the competence of the river because the largest sizes of material transported are evidently much larger than the orifice size of the samplers routinely used to measure the suspended sediment load.

Although not always captured in the bed material samples, the observations by Robbin (1977) indicate that there are numerous gravel locations throughout the river. He also notes that while they may only 
comprise a small portion of the bed, they can be significant morphologically. Additionally, gravels are extremely important from a habitat perspective. For this reason, a gravel study was conducted in 2011 using visual observations from the 2005 and 2007 geo-referenced Red Hen videos. Using these videos, locations where gravel was present were documented. The following classification system was in the study: GS gravel predominant with some sand present; SG - sand predominant with considerable gravel observed; SPG - mostly sand with possible gravel observed but not definitive, or gravel only observed in a few isolated locations; S - predominantly sand with little to no gravel. The results of this analysis are shown in Table 2-18. The bed classifications for both 2005 and 2007 as well as a composite of the two years are shown in Table 2-18. Also indicated in the Comments column are observations from a 1989 boat trip along the entire river. During this trip, Mr. Robert Rentschler, a geomorphologist with the Vicksburg District, made meticulous notes of all locations where he observed gravel outcrops. His observations are included in Table 2-18. Based on the composite observations, there was one location with a GS classification, 10 with SG, and 18 with SPG. Note locations where gravel may have been observed in one year but not the other. This suggests that the gravel may be exposed under certain flow conditions but buried under sand at others.

Table 2-18. Bed classification from 2005 and 2007 geo-referenced videos.

\begin{tabular}{|l|l|l|l|l|l|}
\hline $\begin{array}{l}\text { River } \\
\text { Mile }\end{array}$ & Location & $\begin{array}{l}2005 \\
\text { Observation }\end{array}$ & $\begin{array}{l}2007 \\
\text { Observation }\end{array}$ & $\begin{array}{l}\text { Composite } \\
\text { 2005-2007 } \\
\text { Observation }\end{array}$ & Comments \\
\hline 486 & LB & SPG & SPG & SPG & $\begin{array}{l}\text { Mostly sand with a few possible } \\
\text { gravel deposits (Baleshed - } \\
\text { Ajax). Gravel seen here in } \\
1989 .\end{array}$ \\
\hline 477 & RB & SG & SG & SG & $\begin{array}{l}\text { Gravel deposits on mostly sand } \\
\text { bar (much more gravel in } \\
\text { 2007). Gravel seen here in } \\
1989 .\end{array}$ \\
\hline $471 a$ & RB & S & SG & SG & $\begin{array}{l}\text { 2005 sand (sand with gravel on } \\
\text { closure side of dike in 2007). }\end{array}$ \\
\hline 471 & LB & GS & GS & GS & $\begin{array}{l}\text { Local gravel deposit at US end } \\
\text { of Arcada Dikes. }\end{array}$ \\
\hline 470 & RB & S & S & S & $\begin{array}{l}\text { Sand on bar in old Cottonwood } \\
\text { channel - no presence of } \\
\text { gravel. }\end{array}$ \\
\hline
\end{tabular}




\begin{tabular}{|c|c|c|c|c|c|}
\hline $\begin{array}{l}\text { River } \\
\text { Mile }\end{array}$ & Location & $\begin{array}{l}2005 \\
\text { Observation }\end{array}$ & $\begin{array}{l}2007 \\
\text { Observation }\end{array}$ & $\begin{array}{l}\text { Composite } \\
\text { 2005-2007 } \\
\text { Observation }\end{array}$ & Comments \\
\hline 469 & LB & SPG & SPG & SPG & $\begin{array}{l}\text { Mostly sand with a few possible } \\
\text { gravel deposits - gravel not } \\
\text { seen here in } 1989 .\end{array}$ \\
\hline 464 & LB & SPG & - & SPG & $\begin{array}{l}\text { Mostly sand with a few possible } \\
\text { gravel deposits (limited visibility } \\
\text { due to stage in 2007). Gravel } \\
\text { not seen here in 1989. }\end{array}$ \\
\hline 461 & RB & $S G$ & SPG & $S G$ & $\begin{array}{l}\text { Gravel on bar, mostly sand } \\
\text { (more sand less gravel in } \\
\text { 2007). Gravel seen here in } \\
\text { 1989. }\end{array}$ \\
\hline 456 & LB & $S G$ & $S G$ & $S G$ & $\begin{array}{l}\text { Mostly sand with some gravel } \\
\text { deposits - gravel seen here in } \\
1989 .\end{array}$ \\
\hline 450 & LB & $S$ & $S$ & $S$ & $\begin{array}{l}\text { Mostly sand in dike fields - } \\
\text { gravel not seen here in } 1989\end{array}$ \\
\hline 447 & RB & $S G$ & $S G$ & $S G$ & $\begin{array}{l}\text { Mostly sand with some deposits } \\
\text { of gravel (also possible gravel } \\
\text { wave).Gravel seen here in } \\
\text { 1989. }\end{array}$ \\
\hline 443 & LB & SPG & $S$ & SPG & $\begin{array}{l}\text { Mostly sand, possibly a little } \\
\text { gravel, but not clear (not much } \\
\text { seen in 2007). Gravel seen } \\
\text { here in 1989. }\end{array}$ \\
\hline 439 & RB & $S G$ & $S G$ & $S G$ & $\begin{array}{l}\text { Mostly sand with local deposits } \\
\text { of gravel (limited visibility due to } \\
\text { stage in 2007). Gravel not seen } \\
\text { here in 1989. }\end{array}$ \\
\hline 435 & RB & $S$ & $S$ & S & Mostly sand on point bar \\
\hline 431 & RB & $S$ & $S$ & S & $\begin{array}{l}\text { Mostly sand observed through } \\
\text { dike field - gravel not seen } \\
\text { here in } 1989 .\end{array}$ \\
\hline 429 & LB & SPG & SPG & SPG & $\begin{array}{l}\text { Mostly sand with possible } \\
\text { gravel - gravel not seen here in } \\
1989 .\end{array}$ \\
\hline 426 & RB & $S$ & SPG & SPG & $\begin{array}{l}\text { Mostly sand on bar (possible } \\
\text { signs of gravel in 2007). Gravel } \\
\text { not seen here in 1989. }\end{array}$ \\
\hline 422 & LB & SPG & SPG & SPG & $\begin{array}{l}\text { Mostly sand with possibly } \\
\text { gravel - gravel not seen here in } \\
1989 .\end{array}$ \\
\hline 420 & RB & $S$ & SPG & SPG & $\begin{array}{l}\text { Mostly sand point bar (possible } \\
\text { signs of gravel in 2007). Gravel } \\
\text { not seen here in 1989. }\end{array}$ \\
\hline
\end{tabular}




\begin{tabular}{|c|c|c|c|c|c|}
\hline $\begin{array}{l}\text { River } \\
\text { Mile }\end{array}$ & Location & $\begin{array}{l}2005 \\
\text { Observation }\end{array}$ & $\begin{array}{l}2007 \\
\text { Observation }\end{array}$ & $\begin{array}{l}\text { Composite } \\
\text { 2005-2007 } \\
\text { Observation }\end{array}$ & Comments \\
\hline 414 & LB & $S G$ & $S G$ & $S G$ & $\begin{array}{l}\text { Mostly sand with some deposits } \\
\text { of gravel - gravel not seen here } \\
\text { in } 1989 .\end{array}$ \\
\hline 409 & RB & SPG & SG & $S G$ & $\begin{array}{l}\text { Mostly sand with some possible } \\
\text { gravel (saw considerable gravel } \\
\text { in 2007). Gravel seen here in } \\
1989 .\end{array}$ \\
\hline 403 & RB & $S$ & $S$ & $S$ & $\begin{array}{l}\text { Mostly sand in dike field - } \\
\text { gravel not seen here in } 1989 .\end{array}$ \\
\hline 398 & LB & SPG & SPG & SPG & $\begin{array}{l}\text { Mostly sand with possible } \\
\text { gravel (poor picture quality). } \\
\text { Gravel not seen here in } 1989 .\end{array}$ \\
\hline 393 & RB & SPG & SPG & SPG & $\begin{array}{l}\text { Mostly sand with possible } \\
\text { gravel - gravel not seen here in } \\
1989 .\end{array}$ \\
\hline 388 & RB & $S$ & $S$ & $S$ & $\begin{array}{l}\text { Mostly sand, no sign of gravel - } \\
\text { gravel seen here in } 1989 \text { at DS } \\
\text { end of island, which is now } \\
\text { tree-lined. }\end{array}$ \\
\hline 384 & LB & $S$ & SPG & SPG & $\begin{array}{l}\text { Mostly sand on large point bar } \\
\text { (2007- mostly sand with } \\
\text { possible gravel). Gravel not } \\
\text { seen here in } 1989 .\end{array}$ \\
\hline 377 & RB & $S$ & SPG & SPG & $\begin{array}{l}\text { Mostly sand on island (possible } \\
\text { signs of gravel in 2007). Gravel } \\
\text { not seen here in 1989. }\end{array}$ \\
\hline 372 & LB & SPG & SPG & SPG & $\begin{array}{l}\text { Mostly sand with possible } \\
\text { gravel in places. }\end{array}$ \\
\hline 369 & LB & SPG & - & SPG & $\begin{array}{l}\text { Mostly sand in dike field but } \\
\text { some possible gravel seen (not } \\
\text { much visible bar in 2007). }\end{array}$ \\
\hline 367 & RB & $S$ & - & $S$ & $\begin{array}{l}\text { Mostly sand in dike field (water } \\
\text { too high in } 2007 \text { to see bars). } \\
\text { Gravel not seen here in } 1989 .\end{array}$ \\
\hline 358 & RB & $S$ & $S$ & $S$ & $\begin{array}{l}\text { Mostly sand in dike field - } \\
\text { gravel not seen here in } 1989 .\end{array}$ \\
\hline 356 & LB & SPG & SPG & SPG & $\begin{array}{l}\text { Mostly sand but possible gravel } \\
\text { locations - gravel seen here in } \\
1989 .\end{array}$ \\
\hline 350 & LB & $S$ & $S$ & $S$ & $\begin{array}{l}\text { Mostly sand - gravel not seen } \\
\text { here in } 1989 .\end{array}$ \\
\hline
\end{tabular}




\begin{tabular}{|l|l|l|l|l|l|}
\hline $\begin{array}{l}\text { River } \\
\text { Mile }\end{array}$ & Location & $\begin{array}{l}2005 \\
\text { Observation }\end{array}$ & $\begin{array}{l}2007 \\
\text { Observation }\end{array}$ & $\begin{array}{l}\text { Composite } \\
\text { 2005-2007 } \\
\text { Observation }\end{array}$ & Comments \\
\hline 346 & RB & SPG & SPG & SPG & $\begin{array}{l}\text { Mostly sand but with possible } \\
\text { gravel observed - gravel seen } \\
\text { here in 1989. }\end{array}$ \\
\hline 341 & LB & S & S & S & $\begin{array}{l}\text { Mostly sand - gravel not seen } \\
\text { here in 1989. }\end{array}$ \\
\hline 337 & RB & SG & SG & SG & $\begin{array}{l}\text { Mostly sand but considerable } \\
\text { gravel also present - gravel not } \\
\text { seen here in 1989. }\end{array}$ \\
\hline 330 & LB & SPG & SPG & SPG & $\begin{array}{l}\text { Mostly sand with possible } \\
\text { gravel in places. }\end{array}$ \\
\hline 326 & RB & SG & SG & SG & $\begin{array}{l}\text { Sand with gravel at head of } \\
\text { island. }\end{array}$ \\
\hline 324 & RB & S & S & S & Sand around island. \\
\hline 321 & RB & SPG & SPG & SPG & $\begin{array}{l}\text { Mostly sand but with possible } \\
\text { gravel observed. }\end{array}$ \\
\hline
\end{tabular}

\section{Bed material summary}

Bed material data routinely collected at the permanent gaging stations (Vicksburg and Natchez) reveal the short- to medium-term variability in bed material properties and downstream trends in sediment characteristics based on repeat data for specific points (gaging ranges) that are widely spaced along the length of the river. These data indicated that there were no sustained temporal trends in the bed material composition at either Vicksburg or Natchez. The average D50 at Vicksburg and Natchez was approximately $0.41 \mathrm{~mm}$ and $0.36 \mathrm{~mm}$, respectively, suggesting that there may be a general downstream, decreasing trend in the bed material.

The Gaines and Priestas (2016) data provide insight into the long-term (decadal) variability and trends in the bed material at the system-scale. Their analysis showed a significant reduction in the amount of gravel in the 1989 and 2013 surveys relative to the 1932 sampling. A downstream fining in the bed material size was also confirmed, with the average $D_{50}$ at Vicksburg and Natchez being approximately $0.36 \mathrm{~mm}$ and $0.3 \mathrm{~mm}$, respectively. These values are slightly less than the data at the permanent gaging stations but are still firmly in the medium sand range.

The Gaines and Priestas (2016) data also show that there were no appreciable amounts of bed material in the very fine sand, silts, and clay 
ranges in the 1989 and 2013 data. As Gaines and Priestas (2016) point out, it is difficult to assign definitive causal links between the observed bed material changes natural and anthropogenic factors. However, one factor that warrants further consideration is the increased slopes that have occurred in the study reach. As discussed in Section 2.4.4, the channel slopes were increased dramatically following the cutoffs in the mid-1930s. Therefore, the bed material samples in 1932 reflect in a much lower energy system than the present-day river, in which the slopes are almost 20\% higher than they were in 1932. With slope increases of this magnitude, it is very conceivable that the finer sediments (very fine sand and finer) are being transported through the reach and are therefore not being found in the bed in appreciable quantities.

The Robbins (1977) data used repeated sampling in 14 potamology reaches between 1966 and 1974 to establish short-term (inter-annual) variabilities, and trends at the reach-scale. Analysis of these data did not reveal any sustained downstream decreasing trends in the bed material composition. The average D5o for the entire reach in the 1966-1974 time period was approximately $0.31 \mathrm{~mm}$.

Taking all these observations together, the results indicate that the bed throughout the Vicksburg District is predominantly formed in sand, with the $\mathrm{D}_{50}$ being squarely in the medium sand range. However, the bed does include significant amounts of gravel at some locations, and this may, evidently, be exposed at the surface periodically.

\subsubsection{Channel geometry trends}

Little et al. (2017) conducted a detailed geometric data analysis for the Mississippi River from ORCC to St. Louis, MO, or approximately RM 325 AHP to RM 180 Above Mouth of the Ohio River. This study documented the long-term trends in the dimension, pattern, and profile of the LMR and Middle Mississippi River. Hydrographic survey data from 1975 to 2013 were used to determine spatial and temporal variations in channel geometry and volume. Trends of geometric change (area, depth, width, conveyance, and channel volume) were identified along defined geomorphic reaches of the river. The following is a brief summarization of the results for the Lake Providence to Old River reach. (For detailed information, the reader is referred to Little et al. [2017].) 
Little et al. (2017) reported a decreasing trend for the period 1975 to 2013 in channel area, hydraulic depth, conveyance, and channel volume for the portion of the study reach from approximate RM 325 to RM 435 in the vicinity of Vicksburg. In this study, they examined the pools and crossings individually and found the patterns of decreasing trends to be similar for both. They attributed these decreases to the general depositional trends in this portion of the river. The absence of significant cross-sectional and volumetric changes in the reach from approximately Vicksburg (RM 435) to Lake Providence (RM 487) led Little et al. (2017) to classify this reach as a transition zone from the depositional trends downstream to more stable conditions (dynamic equilibrium).

The cumulative volume change plots developed by Little et al. (2017) help visualize the observed trends discussed above. These plots allow the spatial extent of the average volumetric change rates over time to be readily determined. The cumulative volume change plots referenced to the Low Water Reference Plane (LWRP) for the entire Vicksburg District reach are shown in Figure 2-35. The study reach is highlighted in the red box. A negative slope of the cumulative volume change curve indicates deposition (negative cumulative volume change) while a positive slope indicates erosion (increasing cumulative volume). If the cumulative volume change curve is neither increasing nor decreasing over some time period, then this is an indication of dynamic equilibrium. As shown in Figure 2-35, the reach from approximately RM 325 to approximately RM 425 near Vicksburg exhibited a consistent rate of channel volume decrease (negative slope) for the 1975 to 2013 time period, indicating that this was a depositional zone during this period. From Vicksburg (RM 435) up to Lake Providence (RM 487), the cumulative channel volume change fluctuated but remained fairly constant in magnitude, indicating that there was no significant net erosion or deposition during this time period.

In summary, the analysis of the channel geometry parameters indicate that the river channel in the lower portion of the study reach (RM 325 to near Vicksburg RM 435) was in a depositional or aggradational state for the 1975 to 2013 time period. The reach upstream of Vicksburg to Lake Providence appears to be a transition reach of little to no change in the channel geometry. This suggests that this reach may be approaching dynamic equilibrium. 
Figure 2-35. Cumulative volume change curves for the Vicksburg District. Study reach outlined in red.

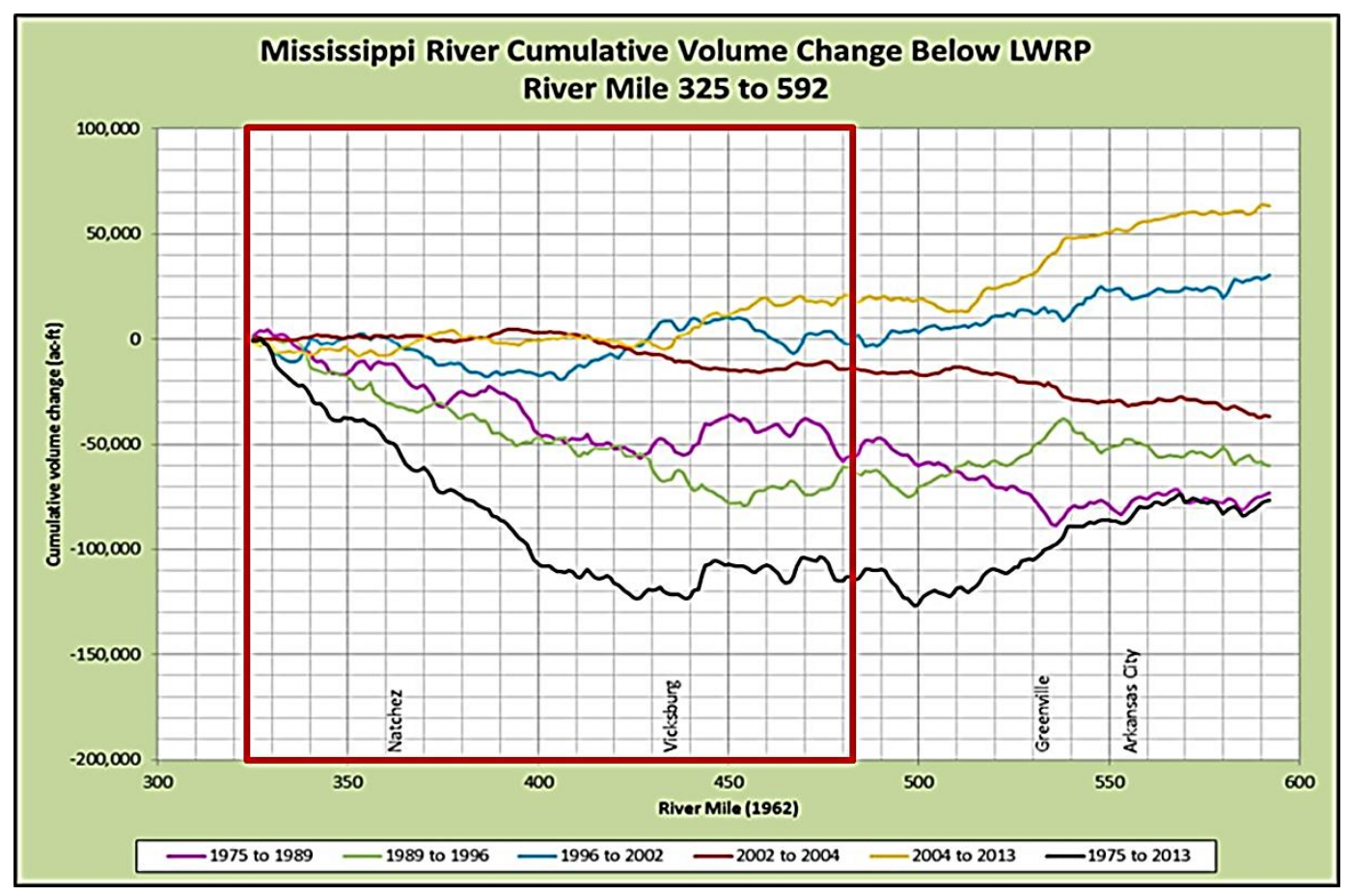

\subsubsection{Suspended sediment trends}

The reductions in the sediment loads on the LMR have been documented by numerous researchers (Keown et al. 1981; Kesel 1988; Horowitz 2010; Meade and Moody 2010; Allison et al. 2012; Little and Biedenharn 2014; Robbins 1977; and Thorne et al. 2008). The reported decreases in the suspended sediment loads typically ranged from approximately $40 \%$ to $85 \%$. A word of caution is warranted here before further discussion of the sediment data. The reported reductions are based on measured suspended sediment loads at various locations along the river, but the benchmark station for most of these studies has been the station at Tarbert Landing, LA. Unfortunately, recent revelations by the U.S. Geological Survey (USGS) have shown that errors in the laboratory analysis have resulted in concentration being significantly higher than they should be. The USGS is currently working to correct this historical database. Within the study reach, there are two long-term sediment stations at Vicksburg and Natchez, which are maintained by the Vicksburg District. Keown et al. (1981) utilized these stations in their analysis. As part of the MRG\&P efforts, these data were recently examined, and numerous problems were identified with the database. Some of these issues were corrected, but there are still numerous issues that need further examination. Unfortunately, these problems do cast a shadow over the reported 
sediment studies. However, even though the study results may have been compromised by the data issues, it is felt that the overall reduction trends that have been reported are reasonable given the magnitude of the changes in the basin resulting from the construction of dams in the upper basin, land conservation programs in the basin, and the comprehensive revetment program along the LMR.

Before progressing further, another cautionary note is needed concerning the interpretation of sediment trends. The reported reductions in sediment loads are typically based on total measured suspended sediment measurements, which are chiefly comprised of fine material (silts and clays). Although a definitive classification of wash load is somewhat controversial, it is generally accepted that silts and clays should be considered to be wash load throughout most portions of the LMR, particularly above Baton Rouge, LA. Therefore, these total suspended sediment measurements are not representative of the bed material loads in the river. Consequently, the reported reductions in sediment load refer to reductions in fine sediment loads and not bed material loads. While most studies have focused on the total suspended sediment trends, Thorne, et al. (2008) and Little and Biedenharn (2014) did segregate the data into fines (silts and clays) and sand loads. Their studies indicated that the fine loads at Tarbert Landing had exhibited a decreasing trend since the 1950 os, but there were no discernible trends in the sand loads.

In summary, it is reasonable to assume that the fine sediment loads in the study reach have decreased significantly over the past 50 to 100 years as a result of upstream dam construction, land conservation efforts in the basin, and the revetment program. These sediments are critically important from an ecological perspective but are less important from a morphological perspective. Although the fine sediment loads have been reduced, there are no data that suggest a reduction in the coarse sediment (bed material loads). In fact, it is more likely that the bed material loads are actually higher today than 50 years ago due to the increased channel slopes through the study reach (see section 2.4.4). 


\section{Summary}

A summary of the geomorphic trends in the study reach is presented here in three sections: (1) Pre-cutoff Period; (2) Cutoff Period; and (3) Postcutoff Period.

\subsection{Pre-cutoff Period (early-1800s to 1929)}

The LMR between the early-180os to the late-1870s was undergoing significant morphological changes as a result of various factors including the New Madrid Earthquakes, clearing of the streambanks for woodburning steamboats and agriculture. These instabilities were evidenced by the extreme width increases (approximately 91\% between 1821 and 1880) and bar and island building. Many of the early navigation problems on the river were aggravated by the caving streambanks, bar building, and channel widening, which created a negative impression of the river system just as it was becoming the main navigation artery for the country.

Levee building in the 1800 s was generally localized and discontinuous. Prior to levees, the LMR valley below Cairo, IL, was characterized by numerous distributary channels that carried high as well as some lower flows into various lowland basins. Major floods in the mid- to late-18oos caused severe damage to some of these early levees, which led to the development of the MRC in 1879. The MRC considered various options to provide dependable navigation within the LMR. The approaches considered included levees, reservoirs, outlets, and cutoffs. After considerable debate, the MRC settled on a levees-only policy. This approach was based on the assumption that the construction of levees would deepen the channel, thereby providing adequate navigation depths.

The MRC also adopted a no-cutoff program in 1884 with the goal of preventing natural cutoffs from occurring. This was accomplished by implementing bank stabilization in areas where a cutoff was considered likely. As a result of this policy, the Waterproof cutoff (RM 377), which occurred naturally in 1884, was the last meander cutoff allowed until 1929 when the MRC decided to allow the Yucatan cutoff just south of Vicksburg to develop.

The river in the post-1880 was still a dynamic river; although compared to the pre-1880s period, the rates of change had slowed considerably. 
Although data are sparse in this period, it does appear, based on specific gage records and historical references (Winkley 1977), that the river in the study reach was slightly aggradational during this period.

The 1927 flood was a galvanizing event for the valley and indeed the entire nation. As a result of the 1927 flood, the MRC recognized that the levees-only approach, which lasted for 50 years, was going to have to be revisited. With the FCA of 1928, the MR\&T was initiated. The MR\&T produced a massive, comprehensive system for flood control and channel stabilization that includes levees, channel modifications, and floodways as well as tributary reservoirs and other basin improvements.

\subsection{Cutoff Period (1929-1942)}

The advantages and disadvantages of artificial cutoffs on the Mississippi River had been debated without consensus by river engineers since the mid-188os. In 1929, the first cutoff since 1884 was allowed to occur at the Yucatan Bend downstream of Vicksburg as part of a study to evaluate the response of the river to a cutoff. After monitoring the Yucatan cutoff for 2 years, the MRC initiated the cutoff program in 1931. Through this program, the USACE constructed 14 artificial cutoffs and allowed 2 natural cutoffs (Yucatan and Leland) to develop between 1929 and 1942 on the LMR. Seven cutoffs were constructed in the study reach between Lake Providence and just south of Natchez. These cutoffs shortened the reach by approximately 62 miles. The cutoffs have had a substantial geomorphic impact on the river compared to any other natural or anthropogenic factor in the past several hundred years.

During the cutoff period between 1929 and 1942, the dominant response in the study reach was channel degradation and slope increase. The stage reductions due to degradation resulting from the cutoffs were in the range of 10 to $12 \mathrm{ft}$ at Lake Providence and Vicksburg. Farther downstream at St. Joseph and Natchez, the stage reductions were slightly less, in the 5 to $7 \mathrm{ft}$ range. The meander cutoffs triggered tremendous slope increases in the study reach. Initial increases in water surface slopes ranged from approximately $25 \%$ to $45 \%$. These increases in slope increased sediment transport capacity significantly, resulting in channel degradation throughout the reach. 


\subsection{Post-cutoff Period (1943 to Present)}

\subsubsection{Channel improvements features}

The period from the mid-1940s through the mid-1960s was one of significant adjustments on the LMR as the river responded to the cutoffs. The cutoffs significantly increased the channel slope and stream power in the system. As a consequence of these changes, bank erosion increased as the channel attempted to regain channel length. It was during this initial period following the cutoffs that an aggressive revetment program was initiated in an attempt to stabilize channel alignments. By the mid-1960s, most of the major meander bends had been stabilized, thereby fixing the alignments in place. The revetment program not only provided for an improved and stable channel alignment but also significantly reduced the sediment loading to the river from streambank erosion. The average annual bank caving volumes were reduced from approximately 350,000,000 cy per year in the pre-revetment period to only approximately 30,000,000 cy per year by the early-1970s based on Winkley 1974 estimation of accumulated annual bank caving volumes. Although this is a reduction in sediment delivery of approximately $90 \%$, further studies are needed to determine what percentage of this material would be considered wash load or bed material load in the river system. Note that with the continuation of the revetment program since the 1970s, the volume of sediment delivered from bank caving has essentially been eliminated.

The cutoffs imposed a new alignment on the channel system that altered the historic crossing patterns in the river. These alignment changes combined with the increased sediment delivery from upstream resulted in increased maintenance dredging throughout the system, which peaked in the late-1970s. After 1970, the amount of maintenance dredging began a long-term decreasing trend as a result of two factors: (1) the revetment program imposed much better planform alignments with more orderly pool-crossing patterns and (2) the construction of training structures (dikes). The dikes are, arguably, the more significant of these two factors, as evidenced by the inverse relation between the amount of dredging and the cumulative length of constructed dikes.

\subsubsection{Channel stability}

The study reach is responding in an expected manner following a series of meander cutoffs. At the upstream end of the reach, represented by the 
Lake Providence gage, the specific gage trends have been relatively stable since the early 1950s. Moving farther downstream, the gages (Vicksburg, St. Joseph, and Natchez) become progressively more aggradational. This suggests that the reach from Lake Providence to Vicksburg may be a transition reach between dynamic equilibrium and the aggradation trends that exists farther downstream. The analysis of channel geometry parameters (area, depth, conveyance, and volume) between 1975 and 2013 support these same trends.

Flow-adjusted stage duration curves were developed to provide supplementary information that is critically important to ecological and geomorphic assessments (particularly sediment transport capacity) but also assists in developing a better understanding of flooding potential. These flow-adjusted stage duration curves indicate that the percentage of time that the flood stage is equaled or exceeded at Lake Providence and Vicksburg is approximately $6 \%$ compared to approximately $12 \%$ to $15 \%$ in the Pre-cutoff Period. Thus, the amount of time that these overbank areas are flooded is less today than in the Pre-cutoff Period. At Natchez, the flood stage elevation is presently equaled or exceeded approximately $9 \%$ of the time as compared to approximately $5 \%$ of the time in the pre-cutoff Period.

As previously noted, the meander cutoff significantly increased the channel slopes ( $25 \%$ to $45 \%$ ). Although these slopes have decreased from their peak conditions in the 1940s, the present-day slopes in the study reach are still higher (generally, approximately 17\%) than in the Pre-cutoff Period.

\subsubsection{Bed material trends}

Analysis of bed material data indicates that the bed throughout the study reach is predominantly formed of sand, with the $\mathrm{D}_{50}$ being squarely in the medium sand range. The $\mathrm{D}_{16}$ fluctuates within the fine sand range while the $\mathrm{D}_{84}$ is typically in the lower end of the coarse sand size classes.

Long-term (decadal) scale analysis by Gaines and Priestas (2016) showed a significant reduction in the amount of gravel in the 1989 and 2013 surveys relative to the 1932 sampling. Although the amount of gravel based on bed material samples has decreased, visual observations confirm that gravel is present throughout the study reach at various locations. While these gravels may comprise a small fraction of the total bed 
material, they are significant from a morphological and ecological perspective. It is also important to recognize that these gravel features may be exposed and covered by sands periodically.

The Gaines and Priestas (2016) analysis also showed that while the 1932 bed did contain sediments in the very fine sand, silts, and clay ranges, these fine sediments were not found in any appreciable amounts in the 1989 and 2013 data. It is difficult to assign definitive causal links between the observed bed material changes natural and anthropogenic factors. However, one factor that warrants further consideration is the increased slopes that have occurred in the study reach as a result of the cutoffs. Therefore, the bed material samples in 1932 reflect a much lower energy system than the present-day river in which the slopes are almost $20 \%$ higher than they were in 1932. With slope increases of this magnitude, it is very conceivable that the finer sediments (very fine sand and finer) are being transported through the reach acting as wash load and are therefore not being found in the bed in appreciable quantities.

\subsubsection{Sediment load trends}

Fine sediment loads have been reduced significantly in the study reach over the past 50 to 100 years as a result of upstream dam construction, basinwide land conservation efforts, and the comprehensive revetment program on the LMR. Although the fine loads have been reduced, it appears that the bed material loads may, in fact, be greater than they were in the Pre-cutoff Period due to the increased slopes resulting from the cutoffs. 


\section{Recommendations}

This investigation provided valuable insight into the morphologic character of the study reach. However, there are still many technology gaps that exist, not only for the study reach but for the entire LMR. The following is a list of MRG\&P efforts that are recommended to further the understanding of this complex river system.

1. Eco-Potamology Reaches. This type of assessment, where a study reach is selected for a detailed geomorphic study, needs to be expanded to other reaches of the LMR. In the 1960s and 1970s, the Vicksburg District divided its district into 25 potamology study reaches where detailed data collection and geomorphic and river engineering investigations were conducted on an annual basis. This was a very effective program that produced valuable findings for the LMR. Given the present-day funding levels as compared to the 1960s and 1970s, it is doubtful that the entire LMR could be divided into distinct potamology reaches. However, based on the current knowledge of the system, the river could be divided into representative reaches where detailed analyses could be conducted and then expanded to the remainder of the system. In contrast to the original potamology reaches, these new reaches would also include an ecological component. The first step in this effort would be to create a team that would identify the appropriate study reaches and the types of analysis that would be required.

2. Long-Term Geomorphic Tool. This report illustrated that the morphologic response of the LMR is complex and must be considered over long time scales (multiples of decades or longer). Geomorphic studies such as this capture the historical morphological response of the system and provide the framework for modeling future scenarios. There is a plethora of existing deterministic river engineering models that focus on short-term (50 years or fewer) investigations of hydraulics, flooding, habitats and channel morphological response, typically within reaches of interest and over project-design time-scales. The ability to consider a wide range of future-year scenarios in a morphological tool that can be run quickly and over annual, decadal, and centennial time-scales, and bounded by levels of confidence on estimates, will undoubtedly provide a major advancement in technology for river engineers and scientists involved in the sustainable management of large rivers such as the LMR. The U.S. Army Engineer 
Research and Development Center has recently initiated the development of a morphological tool capable of long-term forecasting of river channel evolution under a wide range of possible future scenarios. This type of tool could be extremely valuable as a long-term planning and engineering tool for LMR.

3. Sediment Budget. A sediment budget was recently completed for the LMR, which focused on the measured suspended sediment data. While this is a valuable contribution, it only tells part of the story of the Mississippi River sediment loads because it only addresses the fine loads (wash loads) in the system. The delivery of the bed material is a much more complicated process but is one that needs to be fully investigated. This is a critical piece of information because most of the researchers who have published studies in the journals have ignored or misrepresented the role of the bed material loads. This type of study would use much of the recently developed results on slope, stream power, specific gage, channel geometry, suspended sediment data, and bed material samples. It would also need to expand on the estimates of sediment supply from bank caving reported herein to identify how much of this bank material would be delivered as wash load or bed material load to the system. It would then be necessary to weave all this information together to establish the historical and present-day linkages between the sources, pathways, and sinks in the system. Specifically, this would address the following: (1) the major sediment sources in the system and how they have changed over time; (2) the manner in which these sediments have been delivered through the pathways (channel systems), either as bed material or wash load; and (3) the depositional (sink) areas and how they have changed over time. The result would be a conceptual sediment budget that would be extremely valuable in understanding the historical behavior in the system, identifying the impacts of construction features (revetments, dams, etc.) as well as serving to better understand the delivery of sediments through the present-day system.

4. Innovative Daily Stage Recorders. One of the most useful data sets available on the river is the daily stages, which can be used to produce daily water surface slopes. Water surface slopes reflect the energy in the channel system and therefore provide valuable insight into the morphological character of the channel system. Unfortunately, the gaging stations on which these data are based are generally located approximately 50 miles apart. For this reason, a study needs to be conducted to identify more cost-effective methods to obtain daily stage 
data at a much closer spacing. For example, recent studies of dike notching at Coffee Point resulted in the development of a camera system that shows promise as a tool for capturing daily stage readings.

5. Dike Impacts. River training structures (dikes) have been used on the LMR as a navigation aid since the 1960s. These structures have proven extremely effective in reducing the maintenance dredging along the river; however, concerns have been raised about potential increases in flood stages as a result of these structures. Recent studies (empirical and numerical) have been conducted on the 21 dike systems in the Cobb data base. These studies provided considerable insight into the impacts of dikes on channel morphology and flood elevations. However, much work is still needed to fully understand the hydraulic and morphological impacts of these structures. Specifically, a new data base (separate from the Cobb data base) needs to be developed and analyzed. Additional dike systems also need to be analyzed with Adaptive Hydraulics to complement the empirical studies.

6. Characterization of Gravel in the LMR. Gravel deposits in the LMR play an important role with respect to geomorphology and provide spawning habitat for some fish species, including the endangered pallid sturgeon. Recent studies have begun the process to identify locations of gravel along the river. However, sampling over a period of years is needed to acquire a good estimate of the spatial extent of these gravel deposits. Additionally, field data collection is needed at selected locations to field-verify the analytical results, characterize the gravel (mineralogy and size gradations), and obtain an estimate of thickness of gravel deposits.

7. Geologic Outcrops. A recent MRG\&P report (Biedenharn et al. 2018) documented the presence of numerous geologic outcrops throughout the LMR. These outcrops may play an important role in the future morphological character of the river. For this reason, additional studies are needed to (1) more definitively identify the locations and characteristics of these outcrops and (2) develop a better understanding about how these outcrops would actually affect the morphological trends in the river.

8. Floodplain Impacts. The stage duration data developed in this study revealed spatial and temporal variations in the degree of inundation of the floodplain in the study reach. Recent numerical model studies have also indicated the importance of these floodplain features with respect to flood elevations. Further studies are needed to gain a better 
understanding of the channel and floodplain interaction, particularly as it relates to flood elevations.

9. Dike Notching Studies. Dike notching is continuing throughout the LMR. A detailed study of the newly notched Coffee Point dikes just began. The morphological and ecological impacts of dike notching are not fully understood. For this reason, consideration should be given to conducting detailed morphologic and ecological studies at more dike notching sites throughout the LMR. These studies should include both empirical and numerical analyses.

10. Slope and Stream Power Studies. Most all the sediment studies reported in the literature over the past 30 years have indicated significant reductions (50\% to $85 \%$ ) in sediment loads in the river. In fact, this is the generally held belief by most people in the valley. However, as with most issues related to the river, this is oversimplification of a complex process. This report of the Lake Providence to Old River Reach has shown that water slopes are still much greater today than prior to the cutoffs. This suggests that the bed material loads in the river may be much higher than they were 60 years ago. As noted in this report, these increased slopes may be a contributing factor to the reductions in the amount of fines found in the present-day river compared to the river in 1932. Further studies are needed to better understand these slope and stream power trends and the potential implications to the sediment delivery in the LMR.

11. Bed Material Sampling. The Lake Providence to Old River study highlighted the bed material trends in the study reach and showed that there is considerable spatial and temporal variability in these data. Bed material is a critical component in numerical modeling and geomorphic studies. Because of this, consideration should be given to the development of a comprehensive bed material sampling plan along the LMR. Perhaps this could be incorporated into the Eco-Potamology Reach studies mentioned in number 1. 


\section{References}

Allison, M. A., C. R. Demas, B. A. Ebersole, B. A. Kleiss, C. D. Little, E. A. Meselhe, N. J. Powell, T. C. Pratt, and B. M. Vosburg. 2012. "A Water and Sediment Budget for the lower Mississippi-Atchafalaya River in Flood Years 2008-2010: Implications for Sediment Discharge to the Oceans and Coastal Restoration in Louisiana." Elsevier J. of Hydrology 432-433: 84-97.

Biedenharn, D. S., M. A. Allison, C. D. Little Jr., and C. C. Watson. 2017. Large-Scale Geomorphic Change in the Mississippi River from St. Louis, MO, to Donaldsonville, LA, as Revealed by Specific Gage Records. Report No. 10. Vicksburg, MS: U.S. Army Engineer and Development Center.

Biedenharn, D. S., C. D. Little Jr., J. B. Dunbar, and R. A. Gaines. 2018. The Influence of Geology on the Morphologic Response of the Lower Mississippi River. Report No. 17. Vicksburg, MS: U.S. Army Engineer and Development Center.

Elliot, D. O. 1932. The Improvements of the Lower Mississippi River for Flood Control. and Navigation. Volume No. 1. Vicksburg, MS: U.S. Army Corps of Engineers.

Gaines, R.A., and A. M. Priestas. 2016. Particle Size Distributions of Bed Sediments along the Mississippi River, Grafton, Illinois, to Head of Passes, Louisiana, November 2013. MRG\&P Report No. 7. Vicksburg, MS: U.S. Army Engineer Research and Development Center.

Horowitz, A. J. 2010. "A Quarter Century of Declining Suspended Sediment Fluxes in the Mississippi River and the Effect of the 1993 Flood." Hydrological Processes 24(1): 13-34.

Keown, M. P., E. A. Dardeau, Jr., and E. M. Causey. 1981. Characterization of the Suspended-Sediment Regime and Bed-Material Gradation of the Mississippi River Basin. Report 1, LMVD Potamology Program (P-1). Vicksburg, MS: U.S. Army Engineer Waterways Experiment Station.

Kesel, R. H. 1988. "The Decline in Suspended Load of the Lower Mississippi River and its Influence on Adjacent Wetlands." Environmental Geology Water Sciences 11(3): 271-281.

Little Jr., C. D., and D. S. Biedenharn. 2014. Mississippi River Hydrodynamic and Delta Management Study (MRHDM)-Geomorphic Assessment. ERDC/CHL-TR-14-5. Vicksburg, MS: U.S. Army Engineer Research and Development Center.

Little Jr., C. D., D. S. Biedenharn, M. A. Allison, K. Wofford, and T. McCullough. 2017. Channel Geometry Trends of the Mississippi River, Old River Control Complex to St. Louis, Missouri. MRG\&P Report No. 11. Vicksburg, MS: U.S. Army Engineer Research and Development Center.

Meade, R. H., and J. A. Moody. 2010. "Causes for the Decline in Suspended-Sediment Discharge in the Mississippi River System, 1940-2007." Hydrological Processes 24: $35-49$. 
Nordin, C. F., and B. S. Queen. 1992. Particle Size Distributions of bed Sediments along the Thalweg of the Mississippi River, Cairo, Illinois, to Head of Passes, September 1989. Report 7, Potamology Program (P-1). Vicksburg, MS: U.S. Army Corps of Engineers, Lower Mississippi Valley Division.

Robbins, L. G. 1977. Suspended Sediment and Bed Material Studies on the Lower Mississippi River: Potamology Investigations. Report 300-1.Vicksburg, MS: U.S. Army Corps of Engineers, Lower Mississippi Valley Division.

Schumm, S. A., I. D. Rutherfurd, and J. Brooks 1994. Pre-Cutoff Morphology of the Lower Mississippi River: The Variability of Large Alluvial Rivers. Chapter 2. American Society of Civil Engineers Press.

Schumm, S. A., and B. R. Winkley. 1994. The Variability of Large Alluvial Rivers. American Society of Civil Engineers Press.

Thorne, C. R., D. S. Biedenharn, C. D. Little, K. Wofford, T. McCullough, and C. C. Watson. 2017. Bed Material Sizes, Variability, and Trends in the Lower Mississippi River and Their Significance to Calculated Bed Material Loads. MRG\&P Report No. 16. Vicksburg, MS: U.S. Army Engineer Research and Development Center.

Thorne, C. R., O. P. Harmar, C. C. Watson, N. J. Clifford, D. S. Biedenharn, and R. Measures. 2008. Current and Historical Sediment Loads in the Lower Mississippi River. Final Report to the United States Army, European Research Office, London, England, under Contract Number 1106-EN-01. Nottingham, UK: School of Geography, University of Nottingham, University Park.

Watson, C. C., D. S. Biedenharn, and C. R. Thorne. 2013. Analysis of the Impacts of Dikes on Flood Stages in the Middle Mississippi River. Journal of Hydraulic Engineering 139(10): 1071-1078. DOI: 10.1061/ (ASCE) HY.1943-7900.0000786.

WES (Waterways Experiment Station). 1935. Studies of River Bed Materials and Their Movement with Special Reference to the Lower Mississippi River. Paper 17. Vicksburg, MS: U.S. Army Corps of Engineers, Waterways Experiment Station.

Winkley, B. R. 1973. Metamorphosis of a River, a Comparison of the Mississippi River before and after Cutoffs. Mississippi State University, MS: Water Resources Research Institute.

Winkley, B. R. 1977. Man-Made Cutoffs on the Lower Mississippi River, Conception, Construction, and River Response: Potamology Investigations. Report 300-2. Vicksburg, MS: U.S. Army Corps of Engineers, Lower Mississippi Valley Division.

Winkley, B. R. 1994. Response of the Lower Mississippi River to Flood Control and Navigation Improvements: The Variability of Large Alluvial Rivers. Chapter 3. American Society of Civil Engineers Press. 


\section{Unit Conversion Factors}

\begin{tabular}{|l|c|l|}
\hline Multiply & By & To Obtain \\
\hline acres & $4,046.873$ & square meters \\
\hline acre-feet & $1,233.5$ & cubic meters \\
\hline cubic feet & 0.02831685 & cubic meters \\
\hline cubic inches & $1.6387064 \mathrm{E}-05$ & cubic meters \\
\hline cubic yards & 0.7645549 & cubic meters \\
\hline feet & 0.3048 & meters \\
\hline gallons (U.S. liquid) & $3.785412 \mathrm{E}-03$ & cubic meters \\
\hline inches & 0.0254 & meters \\
\hline miles (U.S. statute) & $1,609.347$ & meters \\
\hline square feet & 0.09290304 & square meters \\
\hline square miles & $2.589998 \mathrm{E}+06$ & square meters \\
\hline
\end{tabular}




\section{Acronyms and Abbreviations}

$\begin{array}{ll}\text { AHP } & \text { Above Head of Passes } \\ \text { cfs } & \text { cubic feet per second } \\ \text { cy } & \text { cubic yards } \\ \text { FCA } & \text { Flood Control Act } \\ \text { ft } & \text { foot/feet } \\ \text { in. } & \text { inch } \\ \text { IQR } & \text { interquartile range } \\ \text { LMR } & \text { Lower Mississippi River } \\ \text { mm } & \text { millimeter } \\ \text { MRC } & \text { Mississippi River Commission } \\ \text { MRG\&P } & \text { Mississippi River Geomorphology and Potamology Program } \\ \text { MRT } & \text { Mississippi River and Tributaries } \\ \text { MVD } & \text { Mississippi Valley Division } \\ \text { ORCC } & \text { Old River Control Complex } \\ \text { RM } & \text { river mile } \\ \text { USACE } & \text { U.S. Army Corps of Engineers } \\ \text { USGS } & \text { U.S. Geological Survey }\end{array}$




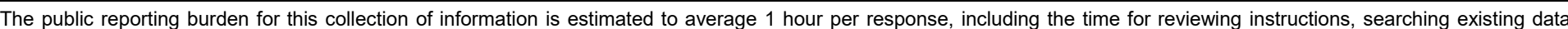

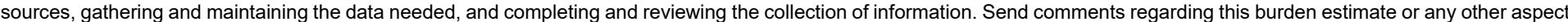

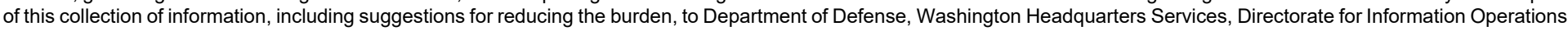

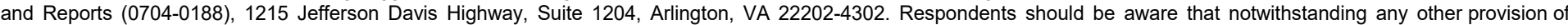
law, no person shall be subject to any penalty for failing to comply with a collection of information if it does not display a currently valid OMB control number. PLEASE DO NOT RETURN YOUR FORM TO THE ABOVE ADDRESS.
1. REPORT DATE
April 2020
2. REPORT TYPE
Final Report
3. DATES COVERED (From - To)

4. TITLE AND SUBTITLE

Lake Providence to Old River Geomorphology Assessment

5a. CONTRACT NUMBER

5b. GRANT NUMBER

5c. PROGRAM ELEMENT NUMBER

\section{AUTHOR(S)}

Waleska Echevarria-Doyle and David S. Biedenharn and Charlie D. Little Jr.

5d. PROJECT NUMBER

No. 470711

5e. TASK NUMBER

5f. WORK UNIT NUMBER

\section{PERFORMING ORGANIZATION NAME(S) AND} ADDRESS(ES)

Coastal and Hydraulics Laboratory

U.S. Army Engineer Research and

Development Center

3909 Halls Ferry Road

Vicksburg, MS 39180-6199

\section{SPONSORING/MONITORING AGENCY NAME(S) AND ADDRESS(ES)}

U.S. Army Corps of Engineers, Mississippi Valley Division

Mississippi River Geomorphology \& Potamology Program

1400 Walnut Street

Vicksburg, MS 39180

Mendrop Engineering Resources, LLC

3530 Manor Drive, Suite 2

Vicksburg, MS 39180

\section{PERFORMING ORGANIZATION REPORT NUMBER}

MRG\&P Report No. 32

10. SPONSOR/MONITOR'S ACRONYM(S) USACE MVD

11. SPONSOR/MONITOR'S REPORT NUMBER(S)

\section{DISTRIBUTION/AVAILABILITY STATEMENT}

Approved for public release; distribution is unlimited.

13. SUPPLEMENTARY NOTES

\section{ABSTRACT}

This report integrates information from previous geomorphic studies coupled with new analysis to provide a comprehensive geomorphic characterization of the Lake Providence (River Mile [RM] 487.2 Above Head of Passes [AHP]) to Old River Control Complex, (RM 317 AHP) reach from the early-1800s to present. Individual components of this study included the following: historical geomorphic studies, development of an events timeline, specific gage records, stage and flow duration trends, trends in water surface slopes, bed material studies, suspended sediment data, channel geometry data, and effects of channel improvement features (cutoffs, dike, revetment, and dredging). These individual assessments were consolidated to develop an overall assessment of how the study reach has evolved since the early-1800s.

\section{SUBJECT TERMS}

Lake Providence (La.) - Geomorphology, Mississippi River-Alluvial plain, River channels

\section{SECURITY CLASSIFICATION OF:}

\begin{tabular}{|l|l|l|}
\hline a. REPORT & b. ABSTRACT & c. THIS PAGE \\
Unclassified & Unclassified & Unclassified \\
& & \\
\hline
\end{tabular}

17. LIMITATION OF ABSTRACT

SAR
18. NUMBER

OF PAGES

80 19a. NAME OF RESPONSIBLE PERSON

Waleska Echevarria-Doyle

19b. TELEPHONE NUMBER (Include area code) 601- 634-4373 